UNIVERSIDADE DE SÃO PAULO

F.F.C.L.R.P - DEPARTAMENTO DE PSICOLOGIA E EDUCAÇÃO

PROGRAMA DE PÓS-GRADUAÇÃO EM PSICOLOGIA

Imaginação e memória nos sermões de Antônio Vieira

Sandro Rodrigues Gontijo

Dissertação apresentada à Faculdade de Filosofia, Ciências e Letras de Ribeirão Preto da USP, como parte das exigências para a obtenção do título de Mestre em Ciências, Área: Psicologia.

RIBEIRÃO PRETO - SP

2011 


\section{SANDRO RODRIGUES GONTIJO}

Imaginação e memória nos sermões de Antônio Vieira

Dissertação apresentada à Faculdade de Filosofia, Ciências e Letras de Ribeirão Preto da USP, como parte das exigências para a obtenção do título de Mestre em Ciências, Área: Psicologia.

Orientadora: Prof. Dra. Marina Massimi

$$
\text { RIBEIRÃO PRETO - SP }
$$


Autorizo a reprodução e divulgação deste trabalho, por qualquer meio convencional ou eletrônico, para fins de estudo e pesquisa, desde que citada a fonte.

\section{FICHA CATALOGRÁFICA}

Gontijo, Sandro Rodrigues

Imaginação e memória nos sermões de Antônio Vieira. - Ribeirão Preto, 2011.

103 p. : il $30 \mathrm{~cm}$.

Dissertação apresentada à Faculdade de Filosofia, Ciências e Letras de Ribeirão Preto/ USP - Dep. de Psicologia e Educação.

Orientadora: Massimi, Marina

1. Antônio Vieira 2. Saberes Psicológicos. 3. Imaginação. 4. Memória 
Nome: GONTIJO, Sandro Rodrigues

Título: Imaginação e memória nos sermões de Antônio Vieira

Dissertação apresentada à Faculdade de Filosofia, Ciências e Letras de Ribeirão Preto da USP, como parte das exigências para a obtenção do título de Mestre em Ciências, Área: Psicologia.

Aprovado em:

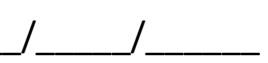

Banca Examinadora

Prof. Dr.

Instituição:

Julgamento:

Assinatura:

Prof. Dr.

Instituição:

Julgamento:

Assinatura:

Prof. Dr.

Instituição:

Julgamento:

Assinatura:

Prof. Dr.

Instituição:

Julgamento:

Assinatura: 


\section{DEDICATÓRIA}

Aos meus pais, Carlos Humberto (Berto) e Sônia, aos meus irmãos Cleiton, Jean e Talita, com afeto e gratidão. 
Agradeço a Prof. Dra. Marina Massimi pela orientação e companhia.

Agradeço ao grupo de pesquisa em história da psicologia, na pessoa de cada um, pelas contribuições e pelo espaço de formação como pessoa e pesquisador que me foi propiciado.

Agradeço ao professor Prof. Dr. João Madeira e a Prof. Dra. Regina Caldana pelas contribuições no trabalho.

Agradeço aos meus amigos pelo encorajamento, pelo apoio, generosidade e caridade durante o período de mestrado.

Agradeço a CAPEs, que proporcionou as condições necessárias para que se tornasse possível esse trabalho. 


\title{
Imaginação e Memória nos Sermões de Antônio Vieira
}

\begin{abstract}
Resumo
A cultura ocidental concebeu a interioridade do ser humano de vários modos segundo o clima cultural e o período histórico. No período colonial, a oratória religiosa oferece uma rica matriz para o estudo de saberes psicológicos veiculados na época. A cultura do século XVII, rotulada como barroco é uma cultura de persuasão, sendo a pregação religiosa o meio de comunicação de massa privilegiado. O objetivo desta dissertação é geral realizar uma reconstrução histórica dos saberes psicológicos contidos nos sermões do jesuíta Antônio Vieira (1608-1697). Procuramos descrever e analisar os conceitos de imaginação e memória e outros conceitos a eles relacionados. Utilizamos como fonte primária a obra de sermões publicada pelo jesuíta em edição moderna. A partir de elementos teóricos retirados seja da História Cultura, seja da História da psicologia, buscamos identificar o contexto de produção e as apropriações feitas pelos sujeitos dos conceitos evidenciados. A leitura dos sermões foi feita a partir da hipótese da unidade teológico-retórico-política de sua "matriz sacramental" proposta por Alcir Pécora. Os sermões estão embebidos em uma matriz epistêmica de orientação aristotélico-tomista. Trata-se de uma psicologia filosófica que remonta ao mundo helênico, porém no século XVII é perpassada pelo humanismo e cristianismo. Nesta concepção há tanto uma visão de homem (uma antropologia filosófica cristã), como um modelo de funcionamento do que poderíamos chamar de "psiquismo", identificado com o termo "alma". Segundo o pressuposto da época, potências internas e externas, paixões, apetites, vontade, intelecto e espírito são os elementos que compõem a alma. Imaginação e memória tem influência preponderante nesta dinâmica e no processo persuasivo.
\end{abstract}

Palavras chave: Antônio Vieira, saberes psicológicos, imaginação, memória. 


\title{
Imagination and Memories in the Sermons from Antônio Vieira
}

\begin{abstract}
Altogether, western culture conceived the interiority of us human beings in many ways according to cultural standards and historical periods. During the colonial period, religious oratory offers a rich environment for the study of psychological knowledge transmitted at that time. XVII century culture, labeled as baroque is a culture of persuasion, having religious preaching as the privileged means of mass communication. The main goal of this study was to historically reconstruct psychological knowledge contained in the sermons of the Jesuit priest Antônio Vieira (1608-1697). Our goal was to describe and analyze the concepts of imagination and memory as well as other concepts to these related. As a primary information source, a recent edition of his published sermons was used. From theoretical elements brought from either the History of Culture or the History of Psychology, we attempted to identify the production context and appropriations made by the subjects of the evidenced concepts. The reading of the sermons had as a starting point the hypothesis of the theological-rhetorical-political unity and its "sacramental matrix" proposed by Alcir Pécora. The sermons are embedded into an epistemic matrix of Thomist-Aristotelian orientation. We have spoken about a philosophic psychology originated in the Hellenic world, however, in the XVII century it is replaced by Humanism and Christianism. Under such conception, there is a vision both of the man (Christian philosophical anthropology), and of a working model of what we could call "psychism", identified by the term "soul". According to assumptions of that such period, internal and external forces, passions, appetites, desire, intellect and spirit are the elements that compose the soul. Imagination and memory have predominant influence in such dynamics and in the persuasive process.
\end{abstract}

Keywords: Antônio Vieira, psychological knowledge, imagination, memory. 


\section{Sumário}

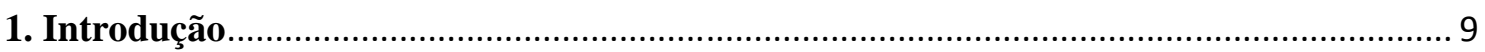

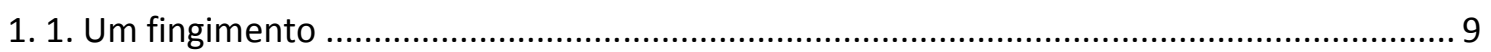

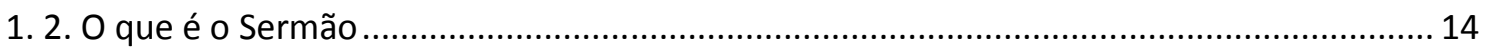

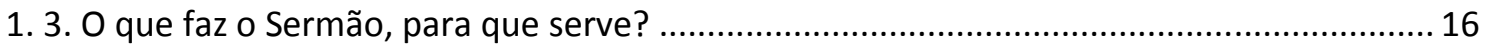

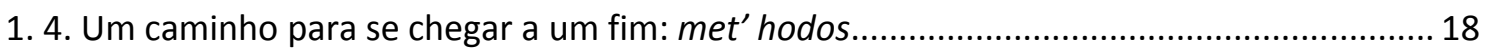

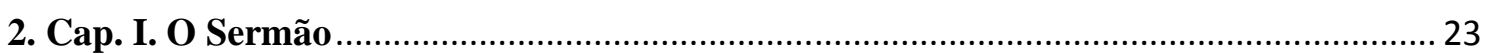

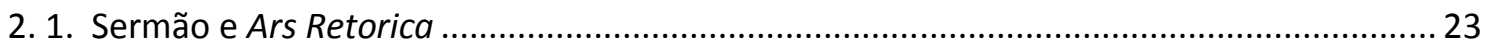

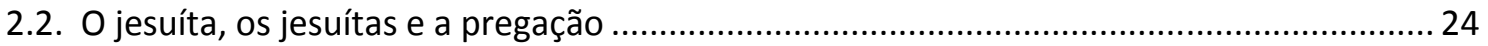

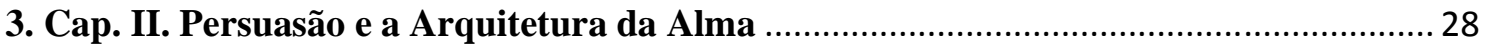

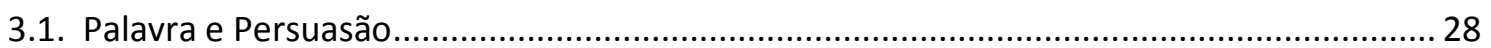

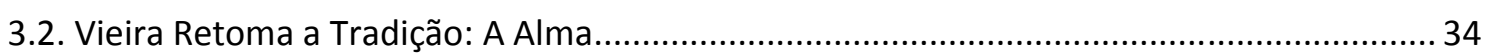

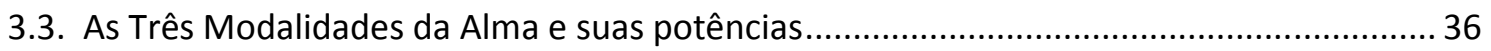

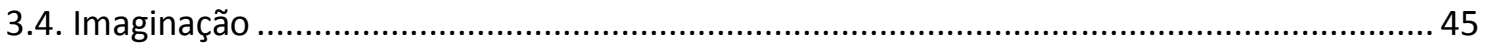

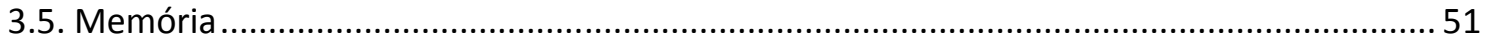

4. Cap. III. A Imaginação e a Memória na antropologia de Vieira ..................................... 58

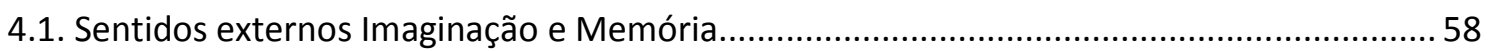

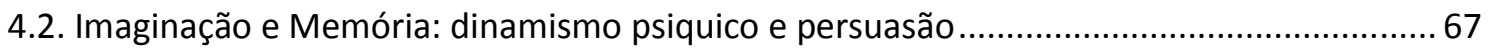

4.3. Imaginação e Memória: Conhecimento e Juízo de Si .......................................................... 71

4.4. Imaginação e Memória: $O$ sentido do tempo e a existência da pessoa ................................. 76

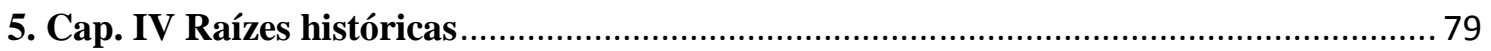

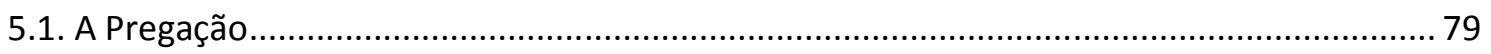

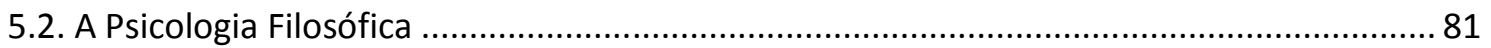

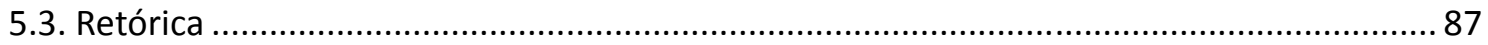

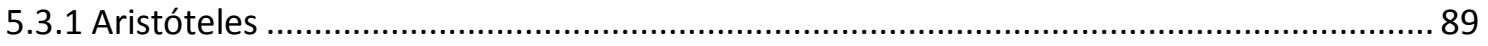

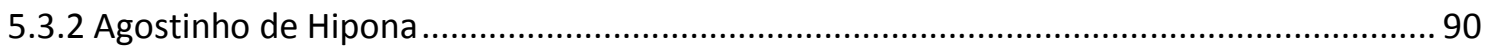

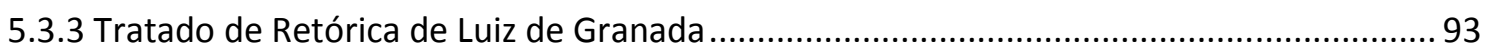

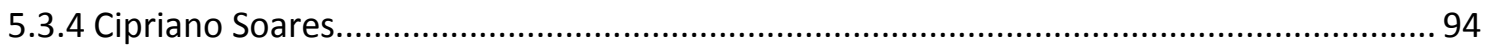

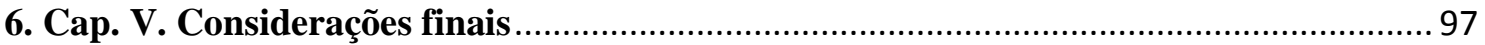

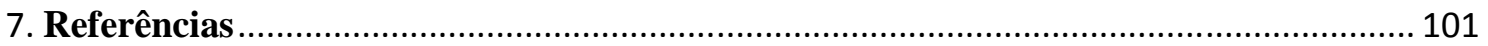




\section{Introdução}

\section{1. Um fingimento}

Caro amigo Gregório,

Inicialmente, desculpo-me pela tardança em dar-te as novas. Finalmente cheguei a terras do Maranhão e só neste momento pude escrever-te. Espero que esta minha missiva te encontre bem. Também espero que a vida em Coimbra esteja toda ela segundo o teu contento. Peço-te apenas que não te deixes soterrar pelos cânones e que em algum momento consiga se desvencilhar e fugir dos padres e tutores que te cerceiam e possa digna e merecidamente encontrar repouso no regaço de uma bela dona. Desculpe-me por este chiste e pelos outros que se seguirão, mas bem sei que não caem mal em seu gosto, segundo seu temperamento.

Como pode imaginar esta empreita, a qual meu pai insiste em me lançar, não me apetece em nada, ou quase nada: este "quase" é o fio de esperança que me distrai e me não deixa enlouquecer nestas terras. Em breve trataremos dele, porém antes explico a pinceladas, ou lembrando minha saudosa França, en passant, minha situação. Conforme havia adiantado em minha última epístola a ti, meu pai resolveu transferir parte de seus negócios de Salvador para estas paragens em que me encontro. Segundo meu pai, já estou em idade de envolver-me de modo mais vigoroso nos negócios da família e não apenas embrenhar-me em estudos conforme a vontade de minha mãe e parentes (franceses, como gosta de assinalar com leve desdém). Meu ímpeto foi tentar explicarlhe que estava eu, justamente na França, empenhado vigorosamente em dar bom cabo das fazendas da família dando razão e sentido a elas, mas considerei que o ilustre fidalgo, meu pai, não me seria empático. Logo, cá estou.

Passarei um ano aqui e depois tornarei aos estudos. Dos meus divertimentos, que me distraem e salvam-me, está (inesperadamente) acompanhar meu pai nos negócios e lidar com a gente daqui. Há de tudo um pouco: negros da terra que são tratados aqui tal qual a negrada nagô que desaporta em Salvador, comerciantes e proprietários de terras que se enriqueceram rápido e que trabalharam e se educaram (sobretudo) pouco. Há garimpeiros, aventureiros, padres, politiqueiros, cristãos novos fugidos e povo simples desta capitania e de várias outras que vem tentar ganhar a vida com os despojos do que 
se produz aqui e cai pelo caminho que vai da roça, da mina ou da mata até o porto para evadir-se a Portugal.

Veja bem meu caro confrade, não são os negócios que me interessam como convenientemente se ilude meu pai, mas é o trato com essa gente que me sustenta e me dá alento. Às vezes me divirto maldosamente, com as agruras e devaneios dos que tem algum poder (ou pensam que o tem) formando uma mistura doida de ganância, avareza e esbanjamento. Às vezes surpreendo-me com as verdades simples que se apresentam nas situações das gentes daqui: nos dias de hoje meu maior mestre tem sido Farias, um velho tropeiro que dizem ser analfabeto, mas por mim, pela idade e pelos dizeres, cursou o quadrivum na Sorbonne. De resto a vida é árida. Nessa terra de chuva, calor e muriçocas meu pai enigmaticamente se sente em casa, se adaptou a terra. Em sua empáfia e arrogância de ex-desembargador tenta travestir-se de popular e desembaraçado dos bens. O resultado é uma figura quimérica e risível, às vezes irritante. Uma mistura de homem de letras envolto em soberba e um bugre. Só duas coisas me achacam mais que seus modos neste lugar: nossa semelhança e minha admiração por ele.

Porém amigo Gregório, o que realmente me fez de pronto escrever-te foi uma novidade que se apresentou. Entenda que o que me faz escrever-te é nossa amizade, mas o escrever-te agora e não ontem, nem amanhã é algo de novo, um acontecimento que queria dividir com alguém que comunga de um mesmo espírito que eu. Não tendo achado no Maranhão ou em França tão zelosa companhia, sou forçado a recorrer a Coimbra.

Hoje tive a oportunidade de ir ouvir um sermão. Há aqui jesuítas, os quais por diversas vezes entram em contendas com os administradores locais, bem como com os colonos de modo geral, no mais das vezes por motivo do apresamento e cativeiro dos negros da terra. Em São Luís, velada ou abertamente, são chamados por muitos de "urubus". Foi-me um regalo quando ouvi o chamamento pela primeira vez, não podia ver um "urubu" que me punha a rir comigo e fazer analogias. Lembro-me de nosso tempo de meninice, que não nos é distante, no Colégio em Salvador tendo lições com vários deles, alguns estrangeiros com o português pior que dos negros, porém respeitosos e respeitáveis. Também me lembro de teu irmão Eusébio, hoje enfurnado em uma roupeta preta. Todos "urubus".

Ao fim da tarde por insistência de meu pai entrei na matriz para ouvir uma pregação que muitos esperavam de um jesuíta que preferia sempre estar nas aldeias dos 
índios, mas hoje vinha à comarca. Vi empoleirado em seu púlpito um "urubu" limpando a goela para começar a grasnar. Qual foi minha surpresa quando fui informado que se tratava do padre Antônio Vieira. Teu irmão deve tê-lo conhecido pessoalmente. Em nosso tempo de Colégio Vieira já não estava mais no Brasil, servia ao rei em Portugal. Destarte, partiu o homem, mas permaneceu a fama. Penso que o bom fidalgo quis agradar-me, sabendo do meu gosto por oratória. Pergunto-me o que teria acontecido para aquele homem das letras, da religião e da política ter deixado a corte e estar embrenhado nestes matos a ter com índios e colonos não menos xucros. Teria ele um pai fidalgo e caprichoso?

Não pretendo estampar-te aqui o sermão, mas dizer-te da experiência que foi ouvi-lo. Padre Vieira partiu da passagem das três tentações feitas no deserto pelo demônio a Cristo. E escolheu a última para pregar a respeito. Reinos por uma alma.

Gregório, já ao ouvir a primeira parte ajuntou-se em mim o tempo da quaresma que em casa é considerado (há jejuns e algumas leves penitências e mais reza que o de costume), mais aquela igreja pouco iluminada e com todas as imagens cobertas de pano roxo a cheirar incenso e os dizeres do padre que arrazoados per si, ainda saiam com a força certa nem mais, nem menos. Quando puxou a Ave Maria, invocando auxílio para a prédica, saiu como um coral afinado. Rezei piamente. Em meus pensamentos meu sarcasmo teve sua última convulsão: éramos pasto de urubu!

Podes imaginar um padre a dizer que temos muito a aprender com o Demônio? Sentenças como esta e tantas outras muito bem lavradas eram postas, causando estranhamento e familiaridade, certo estupor, ao mesmo tempo em que se propunha um jogo de pensamentos instigante. Ele conjecturava e solicitava: "Estai comigo". Escolhi segui-lo. Gregório, como são valiosas as almas.

Ele, animoso, descrevia a diligência e paciência do Demônio ao orquestrar suas tentações, tudo por uma alma. E eu imaginava este em visão. Primeiro em sua espreita nas sombras de arbustos, de pedras e de pensamentos esperando a ocasião. Depois correndo doidamente a bater com os cascos em terra cavoucando-a e ganhando léguas do deserto aos montes, passando por vales e chegando ao mais alto monte. Lembrei-me do tempo de menino, quando via o escravo José se preparar para suas festas de batuque às escondidas. Vestia-se com máscara e roupas estranhas e se punha a pular e dançar em roda. Sabia que era José, mas dava medo. Sabia que poderia não ser conforme a alegoria que o padre compunha, mas sabia que era pra se temer. 
E como a vendemos barato, nossa alma. Por ninharia, por nossas ninharias. Agora encontro lugar para minha simpatia por Farias e meu desprezo por alguns que negociam com meu pai. Farias sem aritmética sabe do valor das coisas, os homens das muitas arrobas e onças, nem tanto.

Porém, o que era pecado individual, tornou-se pecado comunitário. Não era mais o membro que pecava, mas todo o corpo. No Maranhão, o apresamento e cativeiro dos índios se tornara barganha com o Demônio, lá estava a tentação. Segundo o pregador, um povo inteiro a se perder. Vendiam-se as almas pela pretensa posse e trabalhos de alguns tapuias. Trabalho maldito, que nunca poderia render a paga e sempre mal logrado, danação e condenação. Imperou o desassossego.

Veio-me à lembrança que ainda ontem vi alguns negros da terra em uma propriedade que fui visitar com meu pai. Estavam no terreiro à sombra de um grande cajueiro amarrados a um jirau de varas grossas. Ouvia a explicação de que eram ainda imprestáveis para o trabalho. Precisavam ser quebrantados. Lembrei-me ainda da velha ama Tianinha, único índio a nos servir em Salvador. Foi levada a casa de meu avô quando pequena. Era, porém mui querida e era eu que levava palmadas e quinau dela. Segundo o padre Vieira, como remédio nem uns nem outros deviam nos servir.

Sem pudor, ou cerimônia, o pregador havia exposto a fedentina em procissão. Tirava a todos o álibi, estavam avisados e desenganados. Cada um e todos foram afrontados em sua cristandade. Dentro da igreja um murmúrio surgiu, encorpou-se e virou rebuliço, havia fereza.

Troou a voz do padre e granjeou-se novamente a assembléia. Os vapores da cólera, indignação e medo que subiam da assembléia ao púlpito pareciam servir-lhe de partitura. Argumentando e provando com pensamentos, imaginações e Escrituras, ia derribando o ânimo mais acirrado.

Os que estavam ali foram também tocados em seu brio. Naquele momento, aquela igreja era como se fora toda a capitania; e o Maranhão representava toda a cristandade da terra e o reino português, éramos (não me excluo) chamados a testemunhar todas essas coisas. Era estar entre cruz e espada. Manter os cativos não era apenas capricho, apesar das comodidades. Atender ao pregão era por a baixo toda a ordem e falir o Maranhão.

O desafogo veio do mesmo padre: manter-se-iam os escravos adquiridos em guerras justas. Os libertos que quisessem poderiam continuar servindo agora como livres. Os demais iriam para os aldeamentos onde por meio ano cuidariam de suas roças 
e famílias e na outra metade serviriam aos colonos recebendo por isso. O preço seria simbólico, uma ou duas varas de pano, mas que convinha aos índios.

Muitos, ainda que desgostosos, viam a prudência da proposta. Desatou-se o nó que estava no peito apertado pela consciência. Parecia tão apertada a situação que só por Graça de Deus para resolvê-la. Respirava-se. Estava o Demônio e sua tentação posto por sob os pés. Estar ali, Gregório, era terrível e desejável.

Após a pregação ficou o combinado que padre Vieira irá a Portugal ter com o rei. Proporá o deliberado por alguns particulares influentes que estavam presentes, os quais acataram a sugestão de padre Vieira de manejo com os índios.

Interrompo aqui forçosamente a escrita. A fuligem da lamparina me arde a vista e o escrúpulo detém-me a pena. Perdoe-me se te aborreço com esta carta que saiu mais longa do que eu mesmo esperava. Mas para além de dar-te as novas meu desejo é atiçar sua curiosidade e imaginação para ir ouvir este homem. Como já disse ele irá a Portugal e provavelmente pregara em Lisboa. Se minha escrita trôpega não o persuade, faça essa mercê por nossa amizade. O mais maravilhoso e digno de nota do que diz padre Vieira, infelizmente pena alguma pode reproduzir. Depois me escreva dizendo de suas impressões. Ou riras de mim, ou rireis de ti. Sabendo-se do que se trata a pregação daquele, nossas cartas são fumo e palha.

Deus o guarde fiel amigo.

São Luiz, 6 de março de 1653.

Alexandre Montijo 


\subsection{O que é o Sermão}

A pequena ficção que antecede ambicionou despertar em quem a leu alguns dos fenômenos que trataremos neste trabalho. Fenômenos estruturantes do homem, portanto corriqueiros e que nos passam por triviais. O intuito foi tocar de modo tênue em imaginações, lembranças, motivações, sentimentos, bem como evocar impressões (simpatia, antipatia), pensamentos e idéias, dar juízo, propiciar crítica, abarcar a racionalidade. Seguindo a dica dada pelo próprio objeto de estudo, consideramos que o caminho para se atingir o entendimento propriamente passa por outros fenômenos oriundos da vida psíquica. $\mathrm{O}$ próprio personagem remetente da carta transita entre a ressonância que lhe faz o sermão e sua capacidade analítica sobre mesmo, buscando sempre uma síntese. Por tanto, o fato de experienciar as informações, levar em conta suas apercepções, sua consciência imediata auxiliam a intelecção, contribuindo em nosso caminho de expor as idéias da melhor maneira possível, evidenciando sua razoabilidade, buscando o assentir.

Também foi intenção do conto/carta introduzir o tema dos sermões segundo a perspectiva que escolhemos abordá-los. São respeitados em sua perspectiva de oratória sagrada, prática cultural e produção linguística e literária, o que é pertinente ao método que escolhemos. Não obstante, nosso enfoque se dá na ideia de dinamismo psíquico e saberes psicológicos que os sermões contêm. Sendo tais elementos observados na própria construção dos sermões tanto particularmente em sua produção e acomodação ${ }^{1}$, enquanto gênero. Os sermões são também considerados enquanto portadores e transmissores de teoria, advinda da psicologia filosófica que ecoa no período.

Em nosso entender, o sermão é por natureza um gênero "literário" e de oratória (prática cultural) prescritivo, ou seja, busca a afirmação de significados e sentidos. Para Vieira e sua cultura, o discurso é da ordem do instrumental, não se fecha em si, é para

\footnotetext{
${ }^{1}$ Em uma definição concisa, acomodação consistiria em artifício retórico no qual o orador deveria adequar seu discurso ao universo vivencial de seus ouvintes. Segundo Massimi e Freitas (2007): "O autor latino (Cícero) cita a 'acomodação' como elemento indispensável para que se efetive a comunicação na oratória, concebida como um dos principais elos de ligação entre o orador e o ouvinte: se o orador transmitir algo que não faz sentido para o universo vivencial e cultural do público, este não se mobilizará para a persuasão e modificação da conduta. Esse conceito integrou os mais diferentes tipos de atuação retórica, utilizada como instrumento de facilitação da comunicação intergrupal, assumindo uma função muito importante na prática missionária dos jesuítas desenvolvida em várias partes do mundo ao longo da Idade Moderna" (MASSIMI e FREITAS, 2007, p. 111-135).
} 
além dele, uma busca pela verdade. O discurso é um meio e não um fim, não se restringe apenas em literatura ficcional. Há uma teleologia, ou seja, o discurso busca sua finalidade. Há uma busca do "bem viver", digamos uma pedagogia do bem viver, sempre atravessada pelas questões materiais da conformação histórica e da perspectiva relacional com o transcendente: a verdade deve contemplar o Estado e a Divindade, ação política e prescrição teológica e doutrinária.

Os sermões de Vieira estão embebidos em uma matriz epistêmica de orientação aristotélico-tomista e agostiniana. Destarte, desta derivam tanto uma visão de homem (uma antropologia filosófica cristã) como um modelo de funcionamento do que poderíamos chamar de "psiquismo", identificado principalmente com o termo alma. Segundo os pressupostos da época, potências internas e externas, paixões, apetites, vontade, intelecto e espírito são os elementos, que se articulam de maneira dinâmica e contínua, compondo a alma. Falamos aqui de uma psicologia filosófica que remonta ao mundo helênico, porém no século XVII é perpassada pelo humanismo e cristianismo. Tal antropologia e "psicologia" tomam corpo, materialidade, nos sermões a partir da oratória, ou seja, são comunicados através de preceitos definidos, forjados pela tradição. Tais preceitos são em sua gênese a utilização da retórica. É através da retórica que melhor se informa, se apetece e se persuade o outro ${ }^{2}$.

O sermão enquanto gênero de oratória religiosa possui regras e princípios que o regem formando certa sintaxe. Quatro partes estruturantes - exórdio, evocação, confirmação e peroração - constituem o esqueleto ao qual o pregador deverá dar carne e sangue através de ideias, alegorias, exemplos, metáforas, sentenças, soprando-lhe nas narinas através da pronúncia, o modo de dizer. O exórdio é o princípio da narração, pela qual se dispõe o destinatário para ouvir. Nele expõem-se o plano das principais ideias que serão desenvolvidas, e sua temática (matéria), os quais são normalmente extraídos da Sagrada Escritura. Serve para captar a benevolência do ouvinte. Objetiva tornar o ouvinte atento e dócil (GRANADA, 1945). Na evocação, o orador invoca o auxílio divino para a exposição de suas ideias, busca autorização e autoridade para a prédica. É

\footnotetext{
${ }^{2}$ A retórica clássica possui uma longa história. De suas raízes na Grécia podemos citar a sistematização desta arte feita por Aristóteles (384 a.C. - 322 a.C). Da apropriação feita pela civilização romana se apresentam nomes como Marco Túlio Cícero (106 a.C. - 43 a.C) e Lúcio Aneu Sêneca (4 a.C. - 65 d.C). Ainda não menos importante e digno de nota é Aurélio Agostinho (354 - 430), fundador da oratória sagrada.
} 
na confirmação que se dará a amplificação ${ }^{3}$ do tema, seu desenvolvimento de modo artificioso, escrutinando suas partes. Perfazendo o sermão vem a peroração. Recapitulam-se as principais ideias, retoma-se a matéria e exorta-se o auditório a mover-se em direção ao que foi desvelado e proposto como nova prática.

\section{3. O que faz o Sermão, para que serve?}

O sermão deve ser considerado a partir do cerne em que foi produzido, ou seja, enquanto oratória sagrada. Deve-se levar em conta sua dimensão transcendente, sua mística para entender sua lógica interna. Ao buscar a persuasão, a pregação objetiva em última instância a metanóia. O "fruto" da pregação deve ser a conversão do sujeito, de maneira que adira de forma cônscia aos preceitos apresentados. Nesta perspectiva, o pregador é orientado por uma moralidade cristã que o impinge a buscar a proposição revelativa de seu discurso. A palavra só é validada a partir do momento em que é reconhecida como Palavra, ou seja, infusão e efusão do divino evocada por uma hermenêutica apropriada. O ouvinte, enquanto sujeito dotado de capacidade deliberativa se posiciona frente ao que lhe é desvelado. Sendo estes dois movimentos conduzidos pelo pressuposto de uma realidade transcendental que se coaduna na relação comunicativa e lhe dá sentido - a atuação direta e gratuita da divindade. Ou nas palavras de Vieira espelho, olhos e luz:

Para uma alma se converter por meio de um sermão há-de haver três concursos: há-de concorrer o pregador com a doutrina, persuadindo; há-de concorrer o ouvinte com o entendimento, percebendo; há-de concorrer Deus com a graça, alumiando. [...] Que cousa é a conversão de uma alma senão entrar um homem dentro em si, e ver-se a si mesmo? Para esta vista são necessários olhos, é necessária luz, e é necessário espelho. $\mathrm{O}$ pregador concorre como e espelho, que é a doutrina; Deus concorre com a luz, que é a graça; o homem concorre com os olhos, que é o conhecimento. (VIEIRA, 1993, p. 78)

\footnotetext{
${ }^{3}$ Na retórica clássica, a argumentação diz respeito a todo gênero de questões, ao passo que a amplificação diz respeito a certos gêneros de questões e proposições nas quais se disputa acerca da grandeza e da amplitude de algo. No que diz respeito ao fim, a argumentação quer provar algo e reduzir o entendimento ao assenso. Ao passo que a amplificação não visa apenas convencer o entendimento mas também induzir a vontade ao amor, ao ódio, ou a qualquer outro afeto:"Esto es: cuando nos esforzamos á manifestar ser alguna por extremo ibdigna en su género, calamitosa, alegre, triste, miserable, amable, aborrecible, formidable ó apetecible, y otras cosas de esta naturaleza. Pues por este medio abrimos camino para mover las pasiones, persuadir, disuadir, alabar ó vituperar; porque para estas tres cosas principalmente conduce la razon de amplificar."(GRANADA, 1945, p. 530)
} 
Recuperamos aqui um termo utilizado por Vieira, o qual é um dos pressupostos de sua prédica: o desengano. Para desenganar, o pregador "concorre com o espelho" da doutrina, porém é imprescindível a adesão do sujeito, de forma livre, à conversão. A pregação tem como uma de suas funções o desengano, "pregação que descobre e ordena o futuro, ato de discurso que levanta os arranjos providenciais dispondo as coisas do mundo, arte a fazer saltar em frases de impacto as supra-razões que se acumulam na sem-razão do que ocorre" (PÉCORA, 1994, p. 267). O desengano seria como que um desvelamento da realidade. Através de um corpo argumentativo, o pregador indica ao sujeito as razões adequadas de diversos posicionamentos humanos segundo a inscrição transcendente que carregam.

O que se evidencia é que imbricada à produção argumentativa está latente a manifestação da divindade, que deve transbordar o próprio texto e potencialmente ser capaz de gerar ações legitimadas e efetivas na realidade. Isto é evidenciado através de uma matriz sacramental que sustenta o sermão (Pécora 1994). Na perspectiva de Vieira isto se dá, não por um esforço voluntarista por parte do pregador, mas por ser esta uma dinâmica constitutiva da realidade, da natureza. Há uma inscrição de cunho transcendental no real que existe a priori, não sendo constituída pelo homem em sua relação de conhecimento, mas reconhecida por este.

Aqui entra o terceiro elemento indicado por Vieira a concorrer para a metanóia do sujeito, a Graça. A realidade se oferece em gratuidade como elemento de conversão, e afirma uma alteridade em relação ao homem. A realidade é pressuposto para que o ato de conhecer aconteça, assim como a luz é para a visão. Desse modo, interpretando a realidade, o homem é capaz de colher o sentido dos fenômenos que a compõem. Podemos pensar este reconhecimento da realidade como forma de alteridade e a possibilidade de conhecimento como um realismo (GIUSSANI, 2005), no sentido de partir do dado efetivo que se apresenta enquanto sinal sensível. O objeto (a realidade) se afirma e a postura mais condizente é a de reconhecer esta afirmação, evidenciá-la e, então, partir dela para estabelecer o conhecimento.

Respeitando o pressuposto do livre alvedrio (arbítrio), a persuasão só poderia ocorrer se, em primeira instância, Vieira considerasse que o objeto diante dele - seu auditório - já existisse a priori, portanto este tem necessariamente a capacidade de reconhecer a razoabilidade dos argumentos que o pregador propõe. Observamos que subjacente à pregação está a visão de homem, a antropologia contemporânea ao autor. 
Foi (re)compondo todo este arcabouço e simultaneamente mantendo sustentação nele que articulamos nosso recorte a partir dos elementos imaginação e memória. As relações entre os demais elementos da alma, suas capacidades e limites, foram balizadas pelos termos imaginação e memória. Tornou-se necessário colocar em suspenso os conceitos que trazemos destas duas palavras. Esvaziamos o sentido preestabelecido destas e o reconstruímos a partir dos referencias contidos nos sermões. Abandonamos nossa datação histórica e tentamos recuperar outra. Tal cuidado foi tomado para evitarmos o chamado anacronismo.

É Vieira em seus sermões que nos dirá o que significa imaginação e memória. Obviamente há toda uma tradição com a qual Vieira dialoga, da qual devemos nos colocar a par. Segundo nosso entendimento são estes dois sentidos internos ${ }^{4}$, elementos primordiais para a persuasão e consequente metanóia na perspectiva do sermão, bem como conceitos chave que puxam outros conceitos psicológicos. O modelo anímico seiscentista é proposto de modo dinâmico, na qual suas "partes" são relacionais e complementares. Porém, a maneira como memória e imaginação aparecem nos sermões revelam sua relevância e destaque. Assim, mantivemos como questão norteadora o que Vieira apresenta em seus sermões em termos conceituais sobre imaginação e memória, tanto sentidos internos quanto outras acepções e sua articulação com demais potências da alma.

\section{4. Um caminho para se chegar a um fim: met' hodos}

“Terrível e desejável”. Tal qual o afirmado a respeito dos Exercícios Espirituais de Inácio de Loyola, é assim que Alcir Pécora (1994) define o universo sermonário de Antônio Vieira.

A obra dos sermões de Vieira é extensa e profunda. Extensa porque sua produção perfaz um total de 208 sermões segundo nossa edição de referência, "Obras Completas do Padre Antônio Vieira" (Vieira, 1993). Profunda, pois além da qualidade literária e engenhosidade, há toda uma fortuna crítica (literária e histórica) que lhe faz juízo. Acrescenta-se ainda que os sermões por si sejam construções linguísticas com

\footnotetext{
${ }^{4}$ Segundo o referencial aristotélico-tomista, os sentidos internos fariam parte da alma sensitiva (uma das três modalidades que a alma pode se apresentar). Dividem-se em senso comum, cogitativa, imaginação e memória. Os sentidos internos são capacidades que a alma possui de elaborar e organizar apercepções. Retomaremos o tema no item "As três modalidades da alma e suas potências".
} 
diversos ecos estruturais e semânticos que deitam raízes a perder-se em tradições da filosofia, da espiritualidade, da cultura de modo geral, além da historicidade e contexto de produção. Para abarcar tudo isso ao peito, falta-nos braços. Por isso, a necessidade da produção do devido corpus e do recorte da pesquisa.

O universo sermonário de Vieira é extremamente profícuo para pesquisas, possuindo inúmeras maneiras de abordá-lo. Podem-se estabelecer estudos desde a perspectiva da crítica literária, passando pela historiografia em seus diversos aspectos, chegando a perspectivas de espiritualidade e teologia. As perguntas a serem feitas parecem se mostrar inesgotáveis, sendo que as respostas, satisfatórias ou precárias, são contingentes a escolha do enfoque definido pelo pesquisador. Segundo Marrou (1978), existe um número indefinido de perguntas a que um determinado grupo de documentos é suscetível de responder, se for bem interrogado. Neste sentido, acreditando na pertinência de nosso recorte, os sermões serão inquiridos a partir de sua inserção na tradição como meio de pregação, como veiculador e produtor de saberes psicológico, e como forma de atuação de um sujeito histórico.

Principiamos traçando nossa historiografia a partir do campo da história dos saberes psicológicos, o qual se refere:

[...] ao estudo da elaboração dos conhecimentos psicológicos ao longo do tempo nas diferentes culturas. Indica-se por estes nome a reconstrução de conhecimentos e prática psicológicas presentes no contexto de culturas e sociedades específicas, expressivo das diversas 'visões de mundo' que as caracterizam. Entende-se por visão de mundo aquele conjunto de aspirações, de sentimentos e de idéias que reúne os membros de um mesmo grupo e os diferencia de outros grupos sociais (MASSIMI 2008, p. 75).

Em seguida, partimos da hipótese de que o autor, compartilhando a visão de mundo de seus contemporâneos, realizaria uma apropriação da psicologia filosófica de inspiração aristotélico-tomista, em voga no século XVII. Definimos como recorte de pesquisa os tópicos imaginação e memória, entendidos como elementos intrínsecos a psique humana e subsídio imprescindível à persuasão e metanóia buscada pelo pregador. Não obstante, tal hipótese não restringe a atuação do sujeito histórico como mero reprodutor da tradição. É peculiar a maneira pela qual Vieira se apropria e atualiza tais conhecimentos sobre a interioridade humana. Entendemos que tal reconstrução não se fará sem alguma arbitrariedade, por assim dizer, mesmo por este não ser um tema do qual trata Vieira diretamente. Tal arbitrariedade se constitui na insistência do foco de análise em indícios pertinentes ao objetivo por nós pretendido. Sem tal recorte nossa 
pesquisa seria extenuante e totalmente insatisfatória. Desobrigam-se aqui aprofundamentos da área da historiografia geral, da filosofia aristotélico-tomista, da teologia ou mesmo da retórica. Tais conteúdos emergirão na pesquisa na medida em que forem solicitados pelo corpus da mesma. Também, como já assinalado, levamos em conta que o material dos sermões é muito diversificado seja pela temática, pela acomodação aos ouvintes, ou pelo próprio contexto (histórico-social) de produção de cada um. A psicologia filosófica que subjaz aos textos de Vieira aflora claramente apenas com o objetivo de operar como argumento persuasivo. É oferecida como material de partida para uma dedução/indução, exemplo, ou outros artifícios retóricos. Todavia, neste movimento de subjazer e aflorar nos foi possível colher os indícios de tal concepção. Neste sentido, em sua produção textual, Antônio Vieira traz diversos elementos da tradição. Utilizou-se de saberes e conceitos próprios do arcabouço de sua formação jesuítica.

Para o estudo da obra de Vieira fomos fortemente influenciados pelo método proposto por Pécora (1994), apresentado em seu livro "Teatro dos Sacramentos". Pécora (1994) formula a hipótese de uma unidade teológico-retórico-política dos Sermões do Padre Antônio Vieira, fugindo das interpretações tradicionais da figura do jesuíta, apresentada como multifacetada e contraditória. O autor nos traz que esta unidade se manifesta na pregação em seu "modo sacramental", sendo o pregador aquele que, em sua fala, reflete a realidade para o outro, mostrando sua dimensão e significado enquanto sinal efetivo de Deus. Ou seja, a pregação tem como função o desengano, "pregação que descobre e ordena o futuro, ato de discurso que levanta os arranjos providenciais dispondo as coisas do mundo, arte a fazer saltar em frases de impacto as supra-razões que se acumulam na sem-razão do que ocorre" (PÉCORA 1994, p. 267). Desta forma, Pécora (2003) concebe uma maneira de análise da pregação do jesuíta:

Contrariamente à ideia de um Vieira contraditório, penso que a sua pregação ordena-se sistematicamente segundo uma matriz sacramental, entendida como uma técnica de produção discursiva do que se supõe ser uma ocasião favorável á manifestação da presença divina, cuja latência nas palavras do pregador considera-se decisiva para mover o auditório. Move-lo, aqui, significa basicamente, em termos individuais, reorientá-lo na direção da finalidade cristã inscritas na natureza divinamente criada; em termos de ação coletiva e institucional, implica dizer que o sermão deve estar apto a formular hipóteses para uma política pragmática e legítima a ser conduzida pelos Estados católicos na história (PÉCORA, 2003, p.83). 
Pécora (2003) ainda assinala que a unidade teológico-retórico-política não é um ponto de vista teórico, mas operacional e heurístico. Propõe como técnica básica de leitura dos sermões seiscentistas, a apreensão de três linhas semânticas que estariam necessariamente envolvidas no sermão:

[...] primeira, a das comemorações do ano eclesiástico ou litúrgico (tempo santo); segunda, a das passagens escriturais do Evangelho do dia, definidas, por sua vez, pelo calendário litúrgico; terceira, a das circunstâncias presentes na enunciação do sermão, que, segundo a ortodoxia católica, não nega, nem está em contradição com o tempo santo. (PÉCORA, 2003, p. 84)

Deste modo, propusemos que o estabelecimento das fontes, sua organização e levantamentos dos dados fossem feitos levando-se em conta a figura de Vieira e a pregação; a psicologia filosófica jesuítica; a contextualização histórica; a análise historiográfica. Os três primeiros tópicos referem-se aos pressupostos teóricos dos quais partimos para estabelecer corpus e recorte.

A análise historiográfica torna possível reconhecer a multiplicidade própria do nosso objeto de pesquisa. Deste modo, na pesquisa leva-se em conta o sermão enquanto prática social, ou seja, situa-se “... no cruzamento entre uma historia das praticas socialmente diferenciadas e uma história das representações que assume como objetivo explicar as diversas formas de apropriação". (DOSSE, 2001, p. 61)

Encontramos em Michel De Certeau (2000), mais especificamente em sua proposta da operação historiográfica, enquanto epistemologia e método, uma genuína e rigorosa maneira de investigar o tema proposto na pesquisa, erigindo assim mais uma base de sustentação.

Segundo Dosse (2004, p.197), a operação historiográfica proposta por De Certeau não consiste "nem em projetar no passado nossas visões e nossa linguagem presentes, nem a se contentar com uma simples acumulação erudita”. Michel De Certeau (2000) situou a operação historiográfica em um espaço intermediário localizado entre a linguagem de ontem e a linguagem contemporânea do historiador. Porém, tem-se bem claro em De Certeau (2004, p.199) a preocupação do historiador em evitar "um fascínio pelo arquivo que lhe daria a ilusão de ter um acesso direto, sem mediação, ao passado, e por outro lado deve se manter afastado do anacronismo de uma grade de leitura contemporânea, calcada no passado". De Certeau (apud DOSSE , 2004, p. 109) alerta também para os limites de qualquer leitura esquemática, taxônomica, que proporcione, sobretudo, a ilusão de reduzir a singularidade de um fenômeno a seu sistema de codificação: “O próprio historiador estaria se iludindo se acreditasse ter se 
livrado dessa estranheza interna à história guardando-a em algum lugar, fora dele, longe de nós, em um passado fechado".

Assim, fundamentados nesta perspectiva e nos apropriando das ideias de Darnton (apud DOSSE, 2004, p. 194), assumimos uma investigação na vertente da história cultural (o estudo da cultura no sentido antropológico, incluindo as visões do mundo e as mentalidades coletivas). Dentre outros elementos faremos uso do conceito de apropriação utilizado por Roger Chartier (apud DOSSE, 2004, p. 308): "A apropriação, tal como a concebemos, visa uma história social dos usos e interpretações, relacionados com suas determinações fundamentais e inscritos nas práticas específicas que os produzem ${ }^{5}$ ". Partindo destes pressupostos procuraremos identificar de que forma os sermões se inserem na cultura do século XVII, bem como de que maneira Vieira, imerso em sua historicidade, os constrói. Deste modo, consideraremos a história da pregação como meio de transmissão cultural e dentro da pregação abordamos o uso da arte retórica como instrumento de tal transmissão. Seja pela visão de mundo que ajuda a propagar, seja pela técnica em si, que propõe mobilizar o universo interior dos ouvintes: seus afetos, sua vontade, sua razão, sua espiritualidade.

Foram tomadas como fontes secundárias as obras "Retórica" (sec. IV a.c./1994), “De Anima" (sec. IV a.c /2006) e "Ética a Nicómaco" (sec. IV a.c/1996) de Aristóteles, a "Suma Teológica Parte I" (sec. XII /2002) de Tomás de Aquino, o "Livro IV Da Doutrina Cristã" (397-426 /1991) e “Confissões" (397-398/1997) de Agostinho, "De Oratore" (sec. I/) de Cícero e tratados de retórica e oratória sagrada (sobre tudo os de Luiz de Granada importante pregador e teólogo do período). Tais obras foram importantes para subsidiar o estudo do contexto de produção dos sermões, bem como a formação pertinente ao orador. São também significativas para compreender a visão de mundo do período e da tradição que a influencia.

Dentro do possível será explicitada a narrativa do autor e sua relação com saberes psicológicos, sempre amparando-nos na tradição cultural que fundamenta tais conhecimentos. Os temas estão todos imbricados. Portanto, apesar dos capítulos representarem um aprofundamento específico em determinada temática ou enfoque, entendemos que as temáticas e conceitos serão necessariamente retomadas em uma construção textual quase elíptica: retomando e ampliando a argumentação e discussão.

5 CHARTIER, R. Le Monde comme représentation, apud DOSSE, F. História e Ciências Sociais (trad. Fernanda Abreu) Bauru, SP: EDUSC, 2004, p. 308. 


\section{Capítulo I: O Sermão}

\section{1. Sermão e Ars Retorica}

A produção vieiriana, como assiná-la Pécora (1994), faz-se a partir da visão de mundo em que se insere. É o mundo católico contrarreformista do século XVII, de "estética" rotulada como barroca, de governo monárquico e relações coloniais que fornecem as fibras, bem como as cores que o autor disporá para tecer sua obra. $\mathrm{O}$ gênero oratório utilizado por Vieira, o sermão, se organiza quase de maneira autônoma seguindo articulações semânticas e de composição textual pré-concebidas, forjadas pela cultura e pela tradição. O mérito de Vieira consiste na maestria com que se apodera da máquina produtora de sentidos e a atualiza (faz da potência ato). Pécora (1994) afirma:

Assim, pra encerrar, diria que o sermão tem seu início antes ainda de o padre Vieira compor uma só linha dele. Quando começa a pregação já uma máquina de composição está em andamento, pronta a fornecerlhe os principais análogos da invenção e metáforas da elocução, bem como os cruzamentos entre eles (Pecora, 2003, p. 91).

A figura de Vieira é a da eloquência, possuindo seu modo próprio e impar de articular as palavras com seu modo de compreender a realidade. Ainda assim, o inaciano compartilha da visão de mundo de sua época e vive plenamente sua historicidade - o que é coerente com sua "visão sacramental" da realidade (PÉCORA, 1994, p. 41). Como novamente afirma Pécora é necessário considerar o lugar de produção histórica e discursiva do inaciano:

Afinal, não é obvio que Viera fosse o mesmo, ou, pelo menos, que tivesse escrito como os mesmos sentidos os exatos mesmos textos que escreveu, se não tivesse sido igualmente o Padre, católico, jesuíta, missionário e português que acabou sendo pelos tantos anos de seu quase século de vida. (pécora, 1994, p. 44)

Nesta perspectiva podemos ler através dos sermões de Vieira não uma produção subjetiva do autor, mas toda uma contextura feita em um cerne cultural e social. Há uma visão de homem que bebe da antropologia e psicologia filosóficas advindas de sua formação jesuítica. Vê-se também o uso retórico da palavra, amplamente valorizada e reconhecida pela a Igreja de sua época. As questões políticas e econômicas da Metrópole e da Colônia perfazem o contexto de produção dos sermões. 


\subsection{O jesuíta, os jesuítas e a pregação}

Sobre o autor, deixamos aqui algumas breves palavras. Nascido em Lisboa em 1608, Vieira chegou ao Brasil com a família aos seis anos de idade. Estudou no colégio dos jesuítas em Salvador e optou por entrar na ordem religiosa. Em 1642 integrando a embaixada para saudar o novo rei após o fim da união ibérica o então religioso e pregador retornou a Europa. Dez anos depois voltou ao Brasil em uma missão no Maranhão onde fica até 1661, sendo obrigado a se retirar por contendas com os colonos, torna a Portugal. Regressa ao Brasil apenas em 1681, permanecendo aí até sua morte em 1697. Antônio Vieira foi, reconhecidamente já em seu tempo, um dos grandes exemplos da oratória, bem como figura de grande engajamento político. Personagem com uma fortuna crítica muitas vezes controversa, sendo acusado ora de defender a manutenção da exploração colonial e suas mazelas (como a escravidão), ora aclamado como denunciante da mesma. Viera flertou com o poder em diversas cortes europeias (Portugal, França, Roma, Holanda para citar algumas), gozando de prestígio e reconhecimento, criando também contendas e animosidades. Também teve intensa vivência missionária nas selvas e sertões brasileiros. Foi conselheiro, diplomata, réu da Inquisição, professor, mas principalmente exímio pregador.

Tratando-se da obra de sermões de Vieira deve se levar em conta uma profunda variedade do material. Sendo sua produção sempre vinculada ao contexto histórico pertinente ao pregador. O teor da fala é acomodado segundo a audiência, o que vai de cortes europeias, à irmandades de negros no Brasil. Além da diversidade de circunstâncias em que foram pregados os sermões, estes obedecem ao calendário católico, seus tempos litúrgicos, e temas e situações considerados predicáveis, como nascimento e exéquias de nobres, dias de santos e de festas religiosas. Toda esta pluralidade poderia nos dar a sensação de miscelânea, ou de uma prática oratória acomodada circunstancialmente e com plasticidade ilimitada sem o cunho de uma face. Disse o próprio Vieira a respeito de sua obra de Sermões, em seu prólogo:

Os que de presente tens nas mãos (e mais ainda os seguintes) serão todos diversos, e não continuados, quaresmais, santorais, e mariais inteiros, como se usa. Mas o meu intento não é fazer sermonário, e estampar os sermões que fiz. Assim como foram pregados ao acaso, e sem ordem assim tos ofereço ${ }^{6}$. Porque hás de saber que, havendo trinta e sete anos, que as voltas do mundo me arrebataram da minha

6 Na edição por nós utilizada os editores optaram por reorganizar os sermões segundo sua temática. Assim, foram agrupados segundo tempos litúrgicos ou temáticas. 
província do Brasil, e me trazem pelas da Europa, nunca pude professar o exercício de pregador, e muito mais de pregador ordinário, por não ter lugar certo, nem tempo; já aplicado a outras ocupações de Deus e da Pátria, já impedido de minhas frequentes enfermidades, por ocasião das quais deixei de recitar alguns sermões, não poucos, que já tinha prevenido, e também, agora, se darão à estampa (VIEIRA, 1993, v. I, p. 62-63).

Por outro lado, mesmo "pregados ao acaso" e "sem ordem", tais sermões não deixam de seguir certa "globalidade relativa" e dar uma finalidade clara à retórica, onde a dimensão "sacramental [...] fundamenta as analogias da retórica", como afirma Pécora (1994, p.42):

[...] é impraticável uma análise rigorosa da retórica desses sermões se não se examinar o valor que essa eficácia do divino recebe no seio da sua produção humana. Ou seja, essa analise teria que se processar como diz José Mattoso a propósito da "escrita da Historia" que considera adequada com "saber" - tendo em vista uma "lógica de base" que perpassa os sermões individuais e os "insere numa totalidade" com a qual mantêm uma relação essencial". E, como quer que se entenda essa relação essencial a ordenar os sermões, não é possível deixar de considerar o que, nela, se reporta à concepção cristã particular que justifica sua origem e proporciona sua finalidade.

Outro fato importante a ser considerado é que este trabalho ateve-se à parte da retórica que se liga mais diretamente à estrutura formal (estilística, linguística) presente nos sermões e às análises que podem decorrer desta. Os sermões nos chegam hoje como literatura, e o próprio pregador ao dar-lhes a estampa metamorfoseia-se em escritor. Assim, não tocamos diretamente a parte que diz respeito a uma importante dimensão da eloquência propriamente dita, que - como afirma Granada (1945) - é a pronúncia: “à pronúncia cabe acomodar a voz, o gesto, e o rosto à coisa dita" (GRANADA, 1945, p. 490). Voz e gesto são elementos que estabelecem uma comunicação direta via sensorial, e em sua teatralidade expressam e articulam sentidos do universo interior, dando toda uma roupagem de intenção à palavra. É importante lembrar que os sermões são, $a$ priori, organizados para serem pregados, sendo assim a forma tão importante quanto o conteúdo. É o modo como é dito, que dá força e substância à palavra. Para isso nos chama a atenção o próprio Vieira (1993, p. 61): "Da folha que fica atrás (se a leste) haverás entendido a primeira razão, ou obrigação, porque começo a tirar da sepultura estes meus borrões, que sem a voz que os animava, ainda ressuscitados são cadáveres".

No seiscentismo, o tema da persuasão é produtivamente explorado pela oratória religiosa da época, mais especificamente a dos jesuítas. Estes tiveram influência marcante no Brasil, seja por terem assumido o encargo da cristianização da colônia a 
partir de 1549, data de sua chegada na Terra de Santa Cruz, seja por serem os principais representantes da política do padroado: definida amplamente como uma combinação de direitos, privilégios e deveres concedidos pelo papado a Coroa de Portugal como patrona das missões e instituições eclesiásticas católico-romanas em vastas regiões da Ásia e do Brasil (BOXER, 1969).

A concepção "psicológica” própria dos Jesuítas - ordem religiosa de pertença do Pe. Antônio Vieira - é uma das mais bem constituídas da época, sendo também a mais difundida na colônia. Por se basear em uma visão da estrutura antropológica advinda da tradição aristotélico-tomista, proporciona um modelo explicativo do "psiquismo" humano, além de propor uma modalidade de intervenção através da palavra, pelo uso da retórica.

Segundo esta perspectiva, a compreensão da vida interior se daria a partir de certa visão de mundo e de homem. Esta análise assume a forma explicativa de uma espécie de arquitetura da alma - ou arquitetura humana, ou do coração como algumas vezes utiliza Vieira (1993). Esta arquitetura oferece a possibilidade não apenas de articulação de conceitos que formam saberes psicológicos, mas também de ter acesso à teoria do conhecimento aristotélico-tomista que a fundamenta.

A espiritualidade da Companhia de Jesus é perpassada pelos valores do Humanismo filtrados já pela sensibilidade da Idade Moderna, tradicionalmente rotulada como barroca. A essência do ideal humanista é a valorização da personalidade em sua realidade completa (natural e sobrenatural) e nas relações sociais enfatiza-se a importância da solidariedade de modo que cada indivíduo é chamado para contribuir para a salvação do gênero humano, à imitação de Cristo: "Assim era a espiritualidade que pregavam. Aproveita todos os valores possíveis; se adaptando a mentalidade da época; movia-se em um clima tanto elevado quanto humano; se alimentavam das grandes forças do entusiasmo e do amor",

Assim, a esfera do psiquismo humano é concebida como sendo totalmente articulada ao homem integral, completo, tanto no campo interior - sensações, afetos, vontade, intelecto, espírito - quanto no campo exterior, como ser integrado ao mundo e dentro de um corpo social e místico. O ser humano se atualiza em todas as suas potencialidades na medida em que estiver imerso na realidade concreta, no mundo sensível; este último é ligado diretamente ao mundo sobrenatural, através da "sacramentalidade", ou seja, da possibilidade de todas as coisas e fatos serem sinais e 
presentificação de um sentido maior e dotado de transcendência e universalidade: a divindade (PECORA, 1994). 


\section{Capítulo II: Persuasão e a Arquitetura da Alma}

\subsection{Palavra e Persuasão}

A Idade Moderna já foi definida como sendo "a idade da eloquência" (FUMAROLI 1980), tal a influência que a iconografia e a oratória, sobretudo em seu estilo religioso - a pregação -, estabeleceram no período. Devido a profundos reflexos do Concilio de Trento, a pregação tornou-se um dos principais motes da difusão e manutenção da fé e doutrina católica (MASSIMI, 2005). Deve ser levada também em conta a valorização da oralidade na cultura, a grande população iletrada, e acessibilidade restrita as Escrituras Sagradas.

Gozando de relevância e prestígio, a oratória religiosa recebeu grande atenção através do estudo pedagógico da retórica e seus efeitos (MASSIMI, 2005). Isso possibilitou um estudo da ars retorica em profundidade, desde a apropriação dos clássicos - Aristóteles e Cícero - até uma imbricação com valores do Humanismo - de grande influência no séc. XVII (MASSIMI, 2005). A persuasão, objeto e por vezes objetivo da retórica, se torna elemento central da pregação. É pela persuasão que se atinge a metanóia: ato de conversão. Os significantes palavra e verbo divino se mesclam, sendo a expressão verbal também possibilidade de manifestação divina, compondo assim o corpo místico e social da Igreja (MASSIMI, 2005).

Em outra perspectiva, são articulados também saberes sobre os efeitos da pregação nos ouvintes. Justaposto ao conhecimento retórico está o conhecimento sobre a dinâmica da alma humana. Como, para esta cultura, através da enunciação de palavras, alteram-se afetos, pensamentos lógicos e, por conseguinte, a conduta? Há uma apropriação e produção de saberes psicológicos sobre a dinâmica interna da alma. Dessa maneira, a palavra conscientemente trabalhada por uma técnica - a retórica -, pode tocar e ordenar tal interioridade.

A Companhia de Jesus, partindo de uma matriz aristotélico-tomista, desenvolveu seu modelo de dinâmica anímica. Tal modelo é marcado tanto pela retomada da tradição em retórica como a produção em Coimbra de estudos e documentos acerca do tema (MASSIMI, 2005). 
A ars retorica aparece como meio sensível para o desengano. É através da palavra laboriosa que o pregador acessa a interioridade de seus ouvintes, tocando apetites e paixões e ordenando-os de maneira mais apropriada. Lançando mão da proposta de "retórica jesuítica" Vieira aproxima retórica clássica e eloquência cristã, um modelo consagrado em seu tempo e iniciado por Agostinho em sua obra "Da Doutrina Cristã" (1991). Em um modo sacramental, a palavra pode exprimir verdade, já que seria uma forma de manifestação sensível de Deus, de modo que a persuasão provinda do modelo clássico se torna metanóia: processo de conversão da pessoa, fruto que se colhe da pregação.

Assim, inquerimos sobre a maneira do pregador utilizar os conhecimentos retóricos e psicológicos da época para construir seus sermões de modo a mobilizar as potências da alma.

No famoso "Sermão da Sexagésima", o qual o próprio Vieira escolhe como prólogo à sua obra sermonaria ${ }^{8} \mathrm{o}$ inaciano discute, dentre muitas outras coisas, sua concepção sobre o que vem a ser a pregação e como esta deve ser desenvolvida, bem como quem é o pregador. Em metalinguagem fala da pregação ao pregar. Teorética e práxis são contempladas neste eloquente exercício oratório. Sem adentrarmos nas particularidades deste sermão, pretendemos fazer luzir-lhe apenas uma faceta, a da constituição da palavra em sua força imagética e seu entrelaçamento com a dinâmica da alma.

Com rigor e ortodoxia, ao mesmo tempo utilizando-se do engenho, o pregador faz emergir a estrutura argumentativa subjacente aos sermões. Indica suas partes e funções de modo pedagógico segundo sua formação jesuítica. Observa-se enunciado no seguinte excerto, de maneira concisa e potente, o modo pelo qual deve o pregador ordenar seu discurso:

Há-de tomar o pregador uma só matéria, há-de defini-la para que se conheça, há-de dividi-la para que se distinga, há-de prová-la com a Escritura, há-de declará-la com a razão, há-de confirma-la com o exemplo, há-de amplifica-la com as causa, com os efeitos, com as circunstâncias, com as conveniências que se hão-de seguir, com os inconvenientes que se devem evitar, há-de de responder as dúvidas, há-de satisfazer às dificuldades, há-de impugnar e refutar com toda a força da eloqüência os argumentos contrários, e depois disto há-de colher, há-de apertar, há-de concluir, há-de persuadir, há-de acabar. Isto é sermão, isto é pregar, e o que não é isto, é falar de mais alto. Não nego nem quero dizer que o sermão não haja de ter variedade de

\footnotetext{
8 “Servirá de prólogo aos sermões que vos hei-de pregar, e aos mais que ouvirdes esta Quaresma” (Vieira, 1993, Vol. I, p. 76).
} 
discurso, mas esse hão-de nascer todos da mesma matéria, e continuar e acabar nela. Quereis ver tudo isto com os olhos? (Vieira, 1993, p. 90) ${ }^{9}$.

Propõe Vieira: "Quereis ver tudo isto com os olhos?”. E o que ele engenhosamente traz na sequência é uma imagem metafórica (criada com palavras). Compara o sermão a uma árvore com suas raízes, troncos, ramos, folhas, varas, flores e frutos as quais se ligam a Evangelho, assunto e matéria, discursos, ornamento de palavras, repreensões aos vícios, às sentenças e ao "fim que se há de ordenar o sermão" respectivamente (Vieira, 1993, Vol. I, p. 91). E assim, Vieira dá vida "diante dos olhos" à sua estrutura formal retórica, ou seja, é possível "ver pelos ouvidos" criando imagens metafóricas as quais presentificam conceitos e objetos. Criar imagens torna a coisa presente: "ver é crer". Vieira propõe através do uso de metáforas toda uma construção imagética, requisitando fantasmas (imagens) depositados na memória. O poder da imaginação na persuasão é amplamente difundido pelos jesuítas, estes o experienciam em sua formação nos Exercícios Espirituais propostos por Inácio de Loyola ${ }^{10}$ (1985).

No século XVII, uma conceituação muito precisa do significado e do uso das metáforas encontra-se na obra de Tesauro (1965). Para este pensador, a metáfora pode ser definida como uma espécie de "óculo" aristotélico, conforme expressão utilizada por Aristóteles (1994) na "Retórica", cuja função é a de pôr os objetos debaixo dos olhos para bem observa-los. Ela torna a linguagem aguda, de modo análogo ao efeito que a luneta produz na pupila. A metáfora penetra e investiga as noções mais abstrusas para acoplá-las de modo genial, tendo como resultado uma dilatação do campo semântico ordinário (TESAURO, 1965). Os vocábulos metafóricos carregam-se por uma multidão de imagens e noções, proporcionando ao olhar interior um espetáculo surpreendente: "parecendo à mente de quem ouve, ver num só vocábulo, um teatro pleno de maravilhas" (conforme expressão de TESAURO, citado em JORI, 1998, p. 156, trad. nossa). A regra aristotélica da mesotes, ou seja, da medida e da temperança, é rejeitada pelos autores seiscentistas, em favor da afirmação da audácia do engenho humano que, ao criar metáforas, identifica um conceito com outro aparentemente inconciliável. $\mathrm{O}$

\footnotetext{
${ }^{9}$ Sermão da Sexagésima

${ }^{10}$ Inácio de Loyola nos Exercícios espirituais recomenda o uso sistemático da contemplação interior, utilizando os cinco sentidos da imaginação, de modo que o objeto da contemplação envolva o eu num espaço de imaginação mais certo e evidente do que o espaço real. Tais sentidos interiores substituem assim à realidade sensível, uma realidade de imaginação e de fé. Trata-se do recurso inaciano da "compositio loci", uma complexa operação psíquica proposta na Segunda semana dos Exercícios Espirituais, através da qual o sujeito é conduzido a formar no seu interior através dos sentidos internos, a representação de um "lugar" onde é possível o envolvimento em primeira pessoa e que se tornará a seguir espaço de oração e de contemplação.
} 
engenho - faculdade intermédia entre razão e imaginação - torna-se então através da metáfora, capaz de expressar uma sorte de percepção sensorial do pensamento.

Porém, apesar do engenho do pregador, todo esse universo metafórico já dispõe de lugares argumentativos pré-definidos, construídos pela visão de mundo dos homens da época. Assim, quando Vieira lança mão das possibilidades de sentido da metáfora, estes já possuem seu escopo próprio, como já aludido por Pécora (2003) há toda uma máquina de composição pronta a fornecer ao inaciano os tópicos, metáforas e invenções e seus cruzamentos. A maestria de Vieira e sua marca enquanto sujeito histórico está justamente no modo pelo qual opera tal máquina de composição.

Justaposto ao trabalho retórico, é possível identificar alguns elementos nos textos dos sermões, que indicam como se dá o processo de persuasão, havendo uma ação nos mecanismos internos da alma. Tais mecanismos são bem estabelecidos e determinados pela filosofia da Segunda Escolástica (ZANLONGHI, 2003). Nesta concepção a intelecção se dá tanto pela apreensão de espécies ${ }^{11}$ sensíveis, como espécies inteligíveis (impressas e expressas), sendo estas últimas do campo da imaginação.

No dinamismo psíquico, a transformação do objeto sensível para a palavra acontece segundo certa ordem, segundo Zanlonghi (2003): o objeto suscita, na inteligência do sujeito humano, a espécie sensível impressa, a qual origina a espécie sensível expressa, ou seja, a imagem, ou fantasma da coisa. Tal reprodução representativa do objeto, por sua vez, cria a espécie inteligível impressa, ou seja, proporciona a assimilação intelectual do objeto pela ação do intelecto agente, a saber, o seu reconhecimento pelo intelecto. Finalmente, este reconhecimento produz a espécie inteligível expressa, ou seja, à formulação do conceito, verbum mentis: a palavra. Em suma, o verbum mentis humano necessita sempre de um veículo sensível: a imagem. Portanto, a retórica enfatiza a função de sinal que a imagem tem, utilizando-se de processos analógicos e imaginativos.

Tomando-se novamente como exemplo o "Sermão da Sexagésima", é possível buscar alguns processos analógicos e imaginativos na formulação de conceitos. De

\footnotetext{
${ }^{11}$ Segundo Abbagnano: “... na linguagem da Escolástica medieval, a E. é intermediária do conhecimento, ou seja, o objeto próprio de sensibilidade o do intelecto, enquanto forma que a sensibilidade ou o intelecto abstrai das coisas. Essa doutrina foi expressa com toda a clareza por S. Tomás, que, comentando o trecho do De Anima (III, 8, 431b 21), em que Aristóteles diz que 'a alam é de certo modo todas as coisas', observa: 'Se a alma é todas as coisas, é necessário que elas seja as próprias coisas, sensíveis e inteligíveis [...]. Mas por certo a alma não é a coisa, pois p. ex., na alma não há as pedras, mas a E. da pedra"” (ABBAGNANO, 2003, p. 352)
} 
conceitos mais simples e já estabelecidos, por uso de metáforas, o pregador formula conceitos mais complexos e refinados, facilitando deste modo a assimilação intelectual. Também envolve-se o ouvinte ativamente na evidenciação dos sentidos os quais o pregador pretende desvelar.

Quando Cristo mandou pregar os Apóstolos pelo mundo, disse-lhes desta maneira: (...) Ide, e pregai a toda criatura. Como assim, Senhor? Os animais não são criaturas? As árvores não são criatura? As pedras não são criaturas? Pois hão os Apóstolos de pregar às pedras? Hão-de pregar aos troncos? Hão-de pregar aos animais? Sim: diz S. Gregório, depois de Santo Agostinho. Porque como os Apóstolos iam pregar a todas as nações do mundo, muitas delas bárbaras e incultas, haviam de achar os homens degenerados em todas as espécies de criaturas: haviam de achar homens homens, haviam de achar homens brutos, haviam de achar homens troncos, haviam de achar homens pedras (Vieira, 1993, p. 73-74).

Vieira parte do gênero das criaturas (criaturas racionais, sensitivas, vegetativas e insensíveis) e chega ao temperamento dos homens. Como ele o faz? O discurso começa criando imagens, as quais partem de elementos básicos (elementares) - gênero das criaturas - recapitulando da memória conceitos correspondentes a percepções concretas (homem, animal, planta, pedra). A seguir, age na potência cogitativa, reelaborando conceitos: aproximando imagens passo a passo - imagens (re)criadas por palavras que trazem carga afetiva. $\mathrm{O}$ homem degenerado $(\mathrm{em})$ passa a ser criatura (perde a origem, $\mathrm{o}$ ser). Homem "degenerado em” não "é”, mas é "como se fosse", ou seja, o homem degenerado em pedra, por exemplo, não se torna pedra, mas é "como se fosse" (forma intencional) pedra. Aqui se substitui a ideia concreta de pedra (criatura/objeto), pela representação simbólica/afetiva que ela nos traz (intencionalidade) - é a forma intencional presente na fantasia sendo apreendida e ordenadamente na cogitativa. Através da intencionalidade captada, é possível passar do plano concreto do sensível (dureza, solidez, impenetrabilidade), para o universal abstrato (insensibilidade). Insensibilidade é categoria que qualifica uma posição ética, que apesar de remeter a "temperamento", "personalidade" e, portanto, requerer todo um processo de intelecção para definir o conceito, é acessível de forma bem mais direta, por ser intencional, se temos que "é como pedra". O ouvinte pode não conseguir inteligir de forma direta, racionalizando, mas pode entender a intenção que o discurso propõe, e é por isso que o inteligir passa através da sensibilidade.

Cria-se assim, o conceito de homem-pedra, o qual é reelaborado na potência cogitativa e devolvido à memória, remetendo-se então ao tópico de "vontade endurecida". Mais adiante no sermão o jesuíta recupera o tópico e conceito 
preestabelecidos. Ao evocá-los da memória trazem consigo todos os sentidos até então agregados, não sendo necessário retoma-los. O ouvinte já pode completar por si os sentidos dos conceitos apresentados:

Oh! Deus nos livre de vontades endurecidas, que ainda são piores que as pedras. A vara de Moisés abrandou as pedras, e não pode abrandar uma vontade endurecida: Percutiens virga vis silicem, et eressae sunt aquale largissimae. Inratum est cor Pharaonis (Vieira, 1993, p. 80) ${ }^{12}$.

Vieira (1994) coloca como exemplo, a figura bíblica do Faraó e sua vontade endurecida $^{13}$ para recapitular a ideia do homem-pedra. Retoma o último conteúdo da memória (homem-pedra), dá o exemplo bíblico e por indução ${ }^{14}$ o aplica a todo um gênero (tipo) de ouvinte. Mobilizando novamente a potência cogitativa (através da capacidade intuitiva e indutiva do ouvinte) e estabelecendo uma "nova" memória procura persuadir.

Outro trecho aponta modalidades de mobilização do dinamismo psíquico, no entanto proposto de modo diferente. Parece-nos que o jesuíta busca uma reordenação de imagens e não uma aproximação delas. Vieira, partindo da parábola do semeador, busca dissociar o nome semeador com o ato de semear, valorizando este último. A palavra é redefinida enquanto conceito, palavra e ação são justapostas. Neste exemplo, a imagem evocada pela palavra deve ser uma ação e não um conceito abstrato.

A definição do pregador é a vida e o exemplo. Por isso Cristo no Evangelho não o comparou ao semeador, senão ao que semeia. Reparai. Não diz Cristo: Saiu a semear o semeador, senão, saiu a semear o que semeia: Ecce exiit qui seminat, seminare. Entre o semeador e o que semeia há muita diferença: uma cousa é o soldado, e outra cousa o que peleja; uma cousa é o governador outra o que governa. Da mesma maneira, uma cousa é o semeado, e outra o que semeia; uma cousa é o pregador, e outra o que prega. O semeador e o pregador é nome; o que semeia e o que prega é acção; e as acções são o que dão o ser ao pregador. Ter nome de pregador, ou ser pregador de nome não importa nada; as acções, a vida, o exemplo, as obras, são as que convertem o mundo (Vieira, 1993, p. 82) ${ }^{15}$.

Ao falar do pregador, de sua pessoa ${ }^{16}$, novamente há uma reorganização na potência cogitativa, porém, ainda ao fazer associações, pretende-se dissociar elementos. Por exemplo, diferencia-se os termos: semeador-semear; soldado-pelejar; governador-

\footnotetext{
${ }^{12}$ Sermão da Sexagésima.

${ }^{13}$ Núm., XX, 11.

${ }^{14}$ Segundo o manual de retórica de Luiz de Granada, utilizado na época de Vieira: "Toda argumentacion, ó debe tratarse por induccion o por raciocinacion. Induccion es una oracion que por medio de cosas no dudosas logra el ascenso de aquel a quiense dirige, con cuyos asensos hace que él conceda alguna cosa dudosa, en fuerza de la semejanza de aquellas, a que antes asintió" (Granada, 1945, p. 517).

${ }^{15}$ Sermão da Sexagésima

${ }^{16}$ A "pessoa" é umas das circunstâncias que Vieira aponta para a caracterização do pregador: "Lugar, pessoa, e tempo são aquelas três circunstâncias gerais, com que todo o orador se deve medir, se não quer faltar, nem exceder as leis desta nobilíssima arte, que na natureza racional é primogénita.” (Vieira, 1993, Vol. IV, p. 237)
} 
governar; pregador-pregar. Desta maneira, o foco não está mais no nome (palavra) que remete a conceitos, mas parte de uma ação para definir o conceito. É o ato de semear que diz o que é o semeador e não a ideia do semeador. Obviamente, a ideia do semeador é a do que semeia, mas Vieira parece querer causar certo "estranhamento", quebrando o óbvio ao partir da ação - para valorizá-la - e não do termo (nome). O nome sem a ação ficaria vazio, do mesmo modo como a pregação (nome) sem o exemplo (ação) fica vazio $^{17}$.

\subsection{Vieira Retoma a Tradição: A Alma}

Em outra perspectiva, recompusemos o que Vieira apresenta em seus sermões em termos conceituais sobre imaginação e memória, tanto como sentidos internos, ou segundo outras acepções. Para tal procuramos reconstruir, mesmo que de modo fragmentário, a concepção de alma, enquanto psique, presente nos sermões.

Em um de seus sermões quaresmais Vieira procurou definir para sua audiência o que vem a ser uma alma. O pregador em seu discurso utilizou-se do recurso da amplificação. Assim, indica causas, efeitos e circunstâncias atribuídos à presença ou ausência da alma em um corpo. Apontou as capacidades percebidas e atribuídas aos homens, como manifestação desta "entidade". Deste modo, Vieira definiu no "Sermão da Primeira Dominga da Quaresma” de 1655:

Mas já que somos tão corporais e damos tanto crédito aos olhos, os mesmos olhos quero que nos digam e que confessem o que é a alma. Quereis ver o que é uma alma? Olhai, (diz Santo Agostinho), para um corpo sem alma. Se aquele corpo era de um sábio, onde estão as ciências? Foram-se com a alma, porque eram suas. A retórica, a poesia, a filosofia, as matemáticas, a teologia, a jurisprudência, aquelas razões tão fortes, aqueles discursos tão deduzidos, aquelas sentenças tão vivas, aqueles pensamentos tão sublimes, aqueles escritos humanos e divinos que admiramos, e excedem a admiração, tudo isto era a alma [...] Finalmente os mesmos vícios nossos nos dizem o que ela é. Uma cobiça que nunca se farta, uma soberba que sempre sobe, uma ambição que sempre aspira, um desejo que nunca aquieta, uma capacidade que todo o mundo a não enche, como a de Alexandre, uma altiveza como a de Adão, que não se contenta menos que com ser Deus. Tudo isto, que vemos com nossos olhos, é aquele espírito sublime, ardente, grande, imenso: a alma. Até a mesma formosura, que parece dote próprio do corpo, e tanto arrebata e cativa os sentidos humanos, aquela graça, aquela proporção, aquela

\footnotetext{
${ }^{17}$ Aqui parece haver uma crítica ao nominalismo, filosofia muito presente na época e combatida a partir do Concilio Tridentino: "Ao traçar uma breve história do N., a propósito de Nizólio, Leibniz dizia que 'são nominalistas todos os que acreditam que, além das substâncias singulares, só existem nomes puros e, portanto, eliminam a realidade das coisas abstratas e universais"” (ABBAGNANO, 2003, p. 715).
} 
suavidade de cor; aquele ar, aquele brio, aquela vida: que é tudo senão alma? (VIEIRA, 1993, Vol. I, p.805-807)

O orador propôs uma reflexão do que vem a ser a alma. A proposição parte do negativo, ou seja, de um corpo sem alma. A alma aqui fora definida por sua ausência: um corpo sem alma, sem vida. Num processo de encadeamento argumentativo, Antônio Vieira definiu a alma como aquela que anima e caracteriza um corpo, ao mesmo tempo em que sensibiliza os sentidos dos que veem (observam e percebem) tal corpo. Tal opção argumentativa pareceu-nos conter já a priori certa noção de alma. É claro para Vieira que os dados da percepção e a corporeidade são estruturantes no homem, tanto para este se relacionar com o mundo, como para ser persuadido. O próprio autor escreve em seu "Sermão Da Primeira Dominga da Quaresma" de 1653: "Nós os homens, como nos governamos pelos sentidos corporais, e a nossa alma é espiritual, não a conhecemos; e como não a conhecemos, não a estimamos, e por isso a damos tão barata" (VIIERA, 1993, Vol. I, p. 849). Ainda neste sentido acrescentou em seu "Sermão Da Quinta Terça-Feira da Quaresma":

Os olhos do ídolo (diz Agostinho) ainda que não vêem, vê-os o idólatra; os olhos de Deus, ainda que vêem tudo, o idólatra não os vê, e é tal a propensão e inclinação humana a nos deixarmos levar só do que vemos, que antes quer o idólatra dedicar os seus sacrifícios aos olhos visíveis do ídolo, porque ele os vê, ainda que eles o não vejam, do que aos olhos invisíveis de Deus, ainda que eles o vejam, porque ele os não vê (VIEIRA, 1993, Vol. II, p. 85).

Deste modo, apresentou uma conceituação de alma em seu sentido mais amplo enquanto princípio vital: a alma que anima um corpo. Esta noção seria da esfera do supra-sensível e só pode ser reconhecida e manifestada no corpo, mas não é redutível a este. Também indica uma "essência", do humano. Essência no sentido de congregar e manifestar elementos constituintes e peculiares ao homem. Nela constituem-se as capacidades, virtudes e vícios, a racionalidade e o passional, e até mesmo uma estética vinculada ao corpóreo.

Neste ponto a tradição faz-se presente. Banhando-se na sistematização aristotélico-tomista, a passagem do sermão resgata alguns pressupostos da acepção grega de alma. A alma aparece enquanto forma substancial, não podendo ser detectada pelos sentidos, mas apenas capitada pelo raciocínio filosófico do intelecto. A alma seria a enteléquia de um corpo, no sentido do ser em ato. Porém, sem ser definidora em última instância do ser humano, desconsiderando o corpo. Como já comentado, para Tomas de Aquino o homem é sínolo, constituído de corporeidade e espiritualidade. A 
prerrogativa de matéria e forma está presente também em Aristóteles, como indicam Reale e Antíseri (1990):

... Aristóteles remete-se à sua concepção metafísica hilemórfica da realidade, segundo a qual todas as coisas em geral são sínolos de matéria e forma, onde a matéria é potência e a forma é enteléquia ou ato. [...] Os corpos vivos tem vida mas não são vida. Assim, são substrato material e potencial do qual a alma é a 'forma' e 'ato'. [...] Portanto, a alma é inteléquia primeira de um corpo físico que tem a vida em potência (Reale \& Antisseri, 1990, p. 198).

Sugerindo não haver solução de continuidade neste ponto entre aristotelismo e visão vieiriana, o pregador ao referir-se a um milagre atribuído a Nossa Senhora do Rosário (Sermão Vigésimo Sexto), fala de uma jovem que se manteve viva por tempo sobre-humano, após ter sido atacada por lobos e ter as entranhas dilaceradas. Vieira argumenta que a dificuldade de uma alma entrar em um corpo está na necessidade de intervenção divina para tal, e na facilidade da mesma em desvincular-se do corpo, detendo-se neste segundo aspecto. $\mathrm{O}$ fato de a jovem manter-se viva seria "um prodígio estupendo" (Vieira, 1993, Vol. IV, p. 1178), pois "não só decomposta, mas perdida toda a fábrica interna daquele corpo, sem coração, nem entranhas; a alma, contudo o não deixasse e continuasse a obrar na falta dos mesmos instrumentos" (Vieira, 1993, Vol. IV, p. 1178). A alma é ato primeiro do corpo natural organizado. Sem um corpo organizado, não há alma, vai-se a vida. A alma é princípio formal, ato, enteléquia de um corpo orgânico:

"E a razão desta segunda parte é, porque a alma se define: actus corporis organici potentia vitam habentis. E faltando ao corpo a organização e instrumentos vitais, natural e necessariamente deve deixar, e apartar-se do mesmo corpo, porque estando nela ociosa, não seria acto" (Vieira, 1993, Vol. IV, p. 1179).

\subsection{As Três Modalidades da Alma e suas potências}

Ainda inspirado na filosofia antiga e medieval, o orador apresenta uma visão de alma que assume três dimensões: vegetativa, sensitiva e racional sendo que cada uma possui diversas potências. Ou seja, pensando no termo alma como já descrito, há a possibilidade da alma (princípio vital, ato de um corpo) se atualizar de modos diferentes, tanto em organismos distintos (plantas, animais, homem), como em "níveis" diversos em um mesmo organismo - por exemplo, amalgamadas no homem. Relatando de modo sucinto, algumas ocorrências seriam: "A natureza insensível o perseguiu nas 
pedras; a vegetativa nos espinhos; a sensitiva nas aves; a racional nos homens" (VIEIRA, 1993, Vol. I, p. 73), "O homem é uma substância vivente, sensitiva, racional!” (VIEIRA, 1993, Vol. I, p. 578), “... que o homem, criatura racional, a mais nobre, a mais viva, e a mais sensitiva de todas..." (VIEIRA, 1993, Vol. I, p. 721), "Pela parte do vivente, pela parte do sensitivo e pela parte do racional se vê o homem aqui nas mais apertadas angústias" (VIEIRA, 1993, Vol. I, p. 700).

Pode-se observar que o jesuíta utiliza desta sistematização para definir desde uma cosmogonia: “... e a mesma vida, que com nome de espírito se movia escuramente sobre os abismos, também a digeriu, em três vidas, vegetativa nas plantas, sensitiva nos animais, racional no homem" (Vieira, 1993, Vol. IV, p. 781); até uma antropologia filosófica.

Em uma visão humanista, Vieira apresenta o homem como compilação, síntese de toda a criação. Compreendendo em si todas as partes do que foi criado no mundo, viventes e não viventes, porém não redutível a nenhuma delas:

Porque o homem, dos elementos tem o corpóreo; das plantas tem o vegetativo; dos animais tem o sensitivo; dos anjos tem o racional. Essa foi a razão e o sentido (como notou Santo Agostinho) com que Cristo chamou ao homem toda criatura, quando disse aos Apóstolo; Praedicate omni creature: porque o homem é um compêndio universal de todas as criaturas, cada uma, segundo sua própria natureza, estão recopiladas e retratadas no homem. [...] ainda que o homem, considerado por partes, era semelhante às criaturas; considerado todo o homem, ou o homem todo, nenhuma outra criatura era semelhante a ele. As partes eram semelhantes, o todo não tinha semelhante." (Vieira, 1993, Vol. III, p. 434-435)

Na obra do jesuíta, mesmo considerando as várias "componentes" do homem, a alma racional é o cerne argumentativo para definir o humano. Justifica-se assim, aprofundarmos um pouco mais este conceito. A alma racional é muitas vezes traduzida em suas componentes (intelectiva e volitiva) como espírito: “O espírito, e a alma é a mesma cousa: e se tem alguma diferença, é que a palavra espírito significa a parte superior da mesma alma" (VIEIRA, 1993, Vol. IV, p. 1042).

Diferentemente do que parece apontar a acepção da psique grega, a alma racional em Tomás de Aquino (2002) não é o homem. As partes sensitiva e corpórea são valorizadas e precedem a alma racional. Não obstante, a alma racional, através do intelecto, da vontade e do livre alvedrio, atribui ao homem um status que o distancia da natureza e o aproxima da transcendência.

Escreve Vieira no sermão de "Nossa Senhora do Ó" de 1640, sobre a constituição humana em sua geração: “Todos os outros homens, quando se geram e 
concebem no ventre da mãe, não são homens, nem ainda meninos; porque só têm a vida vegetativa, ou sensitiva, e ainda não estão enformados com a alma racional" (VIEIRA, 1993, Vol. IV, p. 212-213). Ou ainda dizendo do ponto de vista moral sobre o não uso (atualização) da razão no "Comento ou Homilia sobre o Evangelho Da Segunda-Feira da Primeira Semana da Quaresma":

No mundo há duas espécies de homens de baixo do mesmo gênero humano: estas espécies são: bons e maus; os bons são homens racionais, os maus são animais irracionais: isto é ser bom, obrar conforme a razão; e o ser mau não é outra cousa, senão obrar contra ela (VIEIRA, 1993, Vol. II, p. 680).

Viera, ao fazer a distinção entre entendimento e vontade, propõe a função de cada um. O julgar seria próprio do entendimento, este é quem é capaz de capitar a verdade (correspondência entre realidade e consciência) ou verossimilhança (o aparentemente verdadeiro), persuade-se, em última instância, através do entendimento. Escreve o inaciano no "Sermão do Santíssimo Sacramento" de 1642:

A causa formal objectiva (como falam os filósofos), ou a razão e motivo, por que damos crédito às cousas, é o ser e verdade delas. Assim o ensina Aristóteles, e dita o lume natural, e o obra a experiência de cada um. Pois se a verdade das cousas é a razão e o motivo por que os entendimentos racionais se persuadem a crer; como diz Cristo, que os judeus O não criam, porque lhes dizia a verdade: $S i$ veritatem dico vobis, non cerditis? (VIEIRA, 1993, Vol. I, p. 1006)

Assim, idealmente o julgar cabe ao entendimento e a vontade é a força motriz, a tensão para executar o que foi compreendido. Mas de forma inapropriada a vontade pode atuar não apenas deliberando a ação, mas julgando-a previamente. Vieira no "Sermão da Segunda Dominga do Advento", argumenta como a vontade com atribuição de julgar erra, pois o julgar não lhe é próprio. A vontade julga conforme o querer ao invés do compreender: "E porque acha mais a vontade sendo cega, que o entendimento sendo lince? Porque o entendimento acha o que há, a vontade acha o que quer" (VIEIRA, 1993, Vol. I, p. 233).

O jesuíta aparentemente parece discutir nestes trechos do mesmo sermão a maneira como julgamos de forma passional e reativa ao invés de ponderarmos racionalmente os fatos:

"Quando entre o entendimento de Deus e a vontade dos homens não houvera aquela infinita distância, bastava só a diferença que há entre vontade e entendimentos, para ser grande a desigualdade destes juízos. Quem julga com o entendimento, pode julgar bem, e pode julgar mal; quem julga com a vontade, nunca pode julgar bem. A razão é muito clara. Porque quem julga com o entendimento, se entende mal, julga mal, se entende bem julga bem. Porém quem julga com a vontade, ou 
queira mal ou queira bem, sempre julga mal; se quer mal julga como apaixonado, se quer bem, julga como cego. Ou cegueira ou paixão, vede como julgará a vontade com tais adjuntos" (VIEIRA, 1993, Vol. I, p. 230)

Deste modo, a vontade aparece nos sermões, tanto como potência que caracteriza o homem concedendo-lhe dignidade através do poder de deliberação (diferindo-se das demais criaturas), como também atributo que pode comprometer-lhe o entendimento, ou desconsidera-lo: “... ou Herodes entendia que era inocente o Baptista, ou não o entendia; se o não entendia, vede a cegueira da vontade, que o fazia entender contra a razão; se o entendia, vede a tirania da vontade, que fazia obrar contra o que entendia." (VIEIRA, 1993, Vol. I, p. 234). O homem entregue a própria vontade não teria parâmetros para encontrar a verdade e atuar na realidade, lidaria apenas com afetos e apetites, nunca chegando a interpretar corretamente os dados sensíveis.

Ainda na perspectiva de uma disposição "negativa" da vontade, no "Sermão da Exaltação da Santa Cruz" de 1645, o pregador disputa a questão de porque muitas vezes a vontade dos maus se realizada. Vieira, propondo uma ética, indica o possível engano de se agir apenas segundo a vontade considerando essa atuação como prêmio e ordem natural, sendo na verdade "castigo":

O maior tirano que há no mundo, é a vontade de cada um de nós. Os tiranos atormentam por fora, este tirano atormenta por dentro. Daqui se argúi, que quando Deus quer dar um castigo, entrega a um homem nas mãos da sua própria vontade; por isso lhes deu por castigo, que fizessem a sua. De sorte que é maior mal estar sujeito aos apetites da vontade própria, que aos impérios da vontade alheia: pois quando a culpa é não querer obedecer à vontade alheia, dá-se por castigo fazer a própria (VIEIRA, 1993, Vol. III, p. 719).

Já alguns atos da alma são formados a partir do entrelaçamento das duas potências, entendimento e vontade, um exemplo é a esperança, escreve o jesuíta no "Sermão do Santíssimo Sacramento" de 1669: "A Esperança é um afecto, que, suspirando sempre por ver, vive de não ver, e morre com a vista" (VIEIRA, 1993, Vol. II, p. 920). Segundo o pregador, seriam necessárias as duas potências para produzi-la. Para Vieira, a esperança tem em parte o desejo que é da vontade e busca seu alívio e em parte a confiança que é asseguramento dado pela razão:

É questão célebre entre os teólogos, se a Esperança reside no entendimento, ou na vontade: os mais defendem que é acto da vontade, os menos que é acto do entendimento; mas a opinião mais provável, e para mim sem dúvida, é que a Esperança compreende ambas as potencias, firmando-se com um pé no entendimento, e com outro na vontade. Por isso a Esperança se chama âncora, nome lhe deu 
S. Paulo: Ad tenendam propositam spem, quam sicut ancoram habemus animae tutam, ac firmam. E assim a âncora para estar segura, há-de prender de uma e da outra parte, assim a Esperança para se firmar bem na alma, não só há-de estar fundada em uma das potências, senão em ambas juntamente. É a esperança um composto de desejo e confiança: com a vontade deseja, e com o entendimento confia: se desejara sem confiança de alcançar, seria somente desejo; mas como deseja e confia juntamente, por isso é Esperança. Daqui se segue, que para a Esperança estar inteiramente satisfeita, parte da satisfação há-de pertencer ao desejo, e parte à confiança: ao desejo para o alívio: à confiança para o seguro [...] (VIEIRA, 1993, Vol. II, p. 923).

Entendemos, portanto, que há uma categorização, presente na tradição ocidental, da qual os sermões se nutrem na filosofia que vai desde Aristóteles (2006), passando por Tomás de Aquino (2002), Agostinho de Hipona (1997) pelos Exercícios Espirituais de Loyola (2002) aos Conimbricenses (ZANLONGHI, 2003) da época de Vieira, dentre outros. Proporemos mais a diante ${ }^{18}$ uma breve reconstrução e análise destes conceitos.

Em seu aspecto mais geral, Vieira em seus sermões se apropria da concepção de dinamismo anímico proposto por Tomás de Aquino (2002) e interpretado pelos Conimbricenses (ZANLONGHI, 2003). Os embates e complementaridades das dimensões anímicas - suas potências e sentidos - são frequentemente retomados. Na argumentação tais categorias aparecem em discussões sobre as relações do homem com si próprio, com os demais, com sua ação no mundo e com o transcendente (Deus, Lúcifer, demônios, anjos, "Cidade da Glória”, etc.). Como se verá nesta sessão e nas seguintes, argumentos que se fundamentam no universo anímico introduzem discussões ético-morais e teológicas, também surgem como demonstrações do processo de persuasão, bem como análise e crítica dos costumes da época. A estrutura anímica também é implicação necessária para o autor discutir sobre o autoconhecimento e auto percepção.

Assinalamos ainda que nos sermões, sensibilidade e intelecto aparecem como tópicos preponderantes para definir tanto a estrutura humana, como o posicionamento do sujeito frente à realidade, a si e diante do outro (seja Deus, sejam os outros homens). Entendemos sensibilidade, na perspectiva vieiriana, como o universo do sensível, ligada à corporeidade e ao nível da alma que se relaciona diretamente com esta, como os apetites e afetos (Aristóteles, 2006). Muitas vezes no seiscentismo (Loyola, 2002) é utilizado o termo sensualidade referindo-se amplamente a dimensão sensitiva, esta é ligada aos "instintos" e prazeres e desprazeres sensoriais - da carne (corpo). Viver

\footnotetext{
${ }^{18}$ Capítulo IV; A psicologia Filosófica.
} 
conforme a sensualidade, portanto, é pautar-se pela alma sensitiva, guiando-se pelos estímulos sensoriais e "instintos". Já o intelecto é um dos representantes da alma racional e o que é próprio do homem. Junto com a vontade e a capacidade de livre alvedrio integra a dimensão espiritual do homem. Nesta perspectiva, no homem as duas dimensões, da sensibilidade e do intelecto, estariam imbricadas. Vemos isto no "Sermão da Quarta Dominga depois da Páscoa” pregado em São Luiz do Maranhão:

Se houve alma triste neste mundo foi a de David, à qual ele tantas vezes perguntou pela causa de sua tristeza: Quare triste es anima mea? E como a alma lhe não respondesse, porque as causas deviam pertencer mais à parte sensitiva que à racional; resolveu-se ele a fazer a pergunta ao todo, como composto de ambas, e falando consigo mesmo, diz assim no salmo 42: Quare tristis incedo, dum affligit me ainimicus? Porque ando eu triste, quando me afligem meus inimigos? (Vieira, 1993, Vol. II, p. 787).

Vieira apresenta a tristeza como uma poderosa de violenta paixão (pertinente à alma sensitiva), a qual pode dominar e destruir o homem. É necessário que Davi se pergunte (sensitiva e racionalmente) sobre o que sente e não fique apenas no nível dos sentimentos. As modalidades sensitiva e racional devem se complementar. Diz ele: "Homem triste: se a tristeza te não tirou ainda o uso da razão, pergunta-se a ti mesmo para onde vais, quo vadis?" (Vieira, 1993, Vol. II, p. 772)

Ainda em relação ao sentido da vida sensitiva e racional que compõe o homem, encontramos o "Sermão de São Gonçalo" no qual o homem é apresentado em suas duas dimensões, a animal (vegetativa e sensitiva) e a racional:

Para inteligência do grande prodígio, que encerra, se há-de supor, que o homem é composto de duas partes, uma animal, e outra espiritual: a animal consta de duas vidas, que são a vegetativa, e sensitiva; e a espiritual consiste em uma só, que é a racional. E que diz S. Paulo? [...] Diz que posto que a parte espiritual seja mais nobre que a animal, a animal contudo é primeiro que a espiritual, e que a espiritual não tem lugar senão depois da animal: Non prius quod, spirituale est, sed quod animale, deinde quod spirituale.[...] O chorar, ou não chorar, pertence à vida sensitiva; porque o choro é efeito do sentimento; o tomar, ou não tomar o peito, pertence à vida vegetativa; porque a nutrição é efeito do alimento: do mesmo modo o chorar por ver a Cristo, e não admitir gosto sem Ele, é efeito da vida racional, e o mais racional da mesma vida. (Vieira, 1993, Vol. II, p. 1230)

Porém é marcante a distinção entre o homem e o animal propriamente dito. Já em uma incipiente percepção dos dados sensíveis, o ser humano colheria noções da universalidade e da intencionalidade das coisas. Isto se daria pela potência cogitativa Aquino (2002). Como definido por Zanlonghi (2003), assiste-se a uma espiritualização da sensibilidade. Este modo de compreender parece ser apresentado por Vieira no 
trecho do "Discurso Primeiro" do sermão "As cinco Pedras da Funda de David" quando afirma:

Verdade é, que o homem e animal, cada um por seu modo, é composto de alma e corpo: mas como a alma do animal é corpórea, e a alma do homem espiritual; o animal ainda que tenha alma, é corpo: Dabantur eis duo corpora; e o homem ainda que tenha corpo, é alma: Da mihi animas (Vieira, 1993, Vol. V, p. 615).

Ainda neste aspecto, no "Sermão do Mandato" de 1643, Vieira traduz de modo didático e elegante a psicologia filosófica de Tomás de Aquino (2002) em sua distinção entre vida sensitiva e vida racional e também a unicidade da alma. Na passagem do sermão, Cristo sobe aos céus e deixa seus discípulos. O inaciano apresenta o Cristo triste por deixar os que ele amava (pautando-se na vida sensitiva), mas, paradoxalmente, alegre por compreender o que fazia (pautando-se na vida racional). A seu modo, utilizando-se do engenho retórico e criando metáforas, o religioso apresenta o conceito de alma e suas manifestações (sensitiva e racional) à medida que se articula em uma tensão própria da espiritualidade e estética "barroca" de seu tempo. No excerto, tristeza e alegria, céu claro e céu escuro, sensitivo e racional, apresentam distinções e simultaneamente, estão compreendidos dentro de um mesmo todo, não perdendo seu antagonismo, ao mesmo tempo compondo-se mutuamente:

"Como podia logo a mesma alma e no mesmo tempo estar triste, e com tanto extremo triste: Tristis est anima mea usque ad mortem? Os teólogos com Santo Tomás, declarando como isto podia ser, distinguem na alma, posto que não tenha partes, uma como parte superior, que é a intelectual; e outra inferior, que é a sensitiva. E deste modo dividida de si para consigo a mesma alma de Cristo, no mesmo tempo podia estar (e estava) alegre e triste juntamente: alegre na parte superior, e sumamente alegre como bem-aventurança: e triste na parte inferior, e sumamente triste, como tão desconsolada e afligida. Vistes o ar coberto, e cerrado de nuvens grossas e espessas, que rebatem os raios do Sol totalmente, e não deixam lugar à luz, a que se nos comunique? Neste caso a parte superior do mesmo ar, e que olha para o Céu, está toda clara e alegre; e a parte inferior que cerca a Terra, toda escura a triste, e não em diversos tempos, senão no mesmo. Pois da mesma maneira, e no mesmo tempo a alma de Cristo, pela parte superior, como gloriosa, estava sumamente alegre, e pela parte inferior, como afligida, e tão afligida, sumamente triste" (VIEIRA, 1993, Vol. II, p. 320).

Em outro caso de engenhosidade, Vieira justapõe ainda as dimensões da alma com a vivência da tradição cristã, indicando como a conduta prática da tradição pode se acoplar a estrutura humana. O exercício das vidas vegetativa, sensitiva e racional é relacionado a jejum, esmola e oração respectivamente. $\mathrm{O}$ argumento vem do "Sermão das Exéquias do Conde de Unhão D. Fernão Teles de Meneses" de 1651, onde o 
pregador, ao exaltar a memória de um nobre, afirma a importância de viver a vida e não apenas durar no tempo:

A vida humana naturalmente considerada, compõe-se de três vidas. A vida vegetativa, com que nos alimentamos; a vida sensitiva, com que sentimos; a vida racional, com que entendemos. A estas três vidas naturais correspondem no espiritual outra três, as quais se conservamnas três mais encomendadas virtudes que temos na Escritura. As virtudes que mais nos encomenda Deus em ambos os Testamentos, são estas três: jejum, esmola, oração. $O$ jejum responde à vida vegetativa; porque com ela nos alimentamos: a esmola responde à vida sensitiva; porque com ela nos compadecemos: a oração responde à vida racional; porque com ela tratamos com Deus. Estas são as vidas que tão altamente nos ensinou S. Paulo naqueles seus três advérbios: Sobrie, et juste, et pie vivamus. Com a primeira vida vivemos para nós, com a segunda para o próximo, com a terceira para Deus (Vieira 1993, Vol. V, p. 1151).

Segundo o inaciano, neste sermão, viver bem é viver racionalmente, obrando segundo a razão. A elaboração no espírito, através de entendimento e vontade, pode criar ações virtuosas que tocam e movem as instâncias do homem. Aqui acena à lembrança os Exercícios Espirituais de Inácio de Loyola (Loyola, 2002), onde por ações deliberadas (movimento racional e volitivo) se propõe mobilizar imaginação, memória, afetos, apercepções para obter vivências espirituais mais intensas e ordenadas.

Ainda vemos as modalidades da alma, sendo utilizadas para introduzir justificativas para as orações comunitárias e a unidade do corpo social e místico no "Sermão décimo sétimo" do Rosário:

"Os homens, os brutos, as árvores crescem, porque têm vida vegetativa: as pedras não têm vida vegetativa, e também crescem: mas como? Dizem os filósofos, que per justa positionem, convertendo cada uma em si, e acrescentando a si o que tem junto de si. E isto mesmo é o que faz a união recíproca dos que oram, quando oram muitos juntos: Multi enim minimi, dum congregantur, fiunt magni" (Vieira, 1993, Vol. IV, p. 854)

Outro dado é a descrição das potências constituintes da alma que se atualizam. No seguinte excerto do "Sermão da Primeira Sexta-Feira da Quaresma" de 1649, o pregador levanta um possível argumento contrário à tese de amar o inimigo e a dificuldade que isto seria para um "coração de barro", ou seja, para a alma e o corpo do homem. Para tal, ele ilustra o funcionamento da alma (e em consequência do corpo) frente ao aparente sentido antinatural de caber em si o amar a quem lhe odeia e aborrece. São descritas as potências da alma e suas ações. O tom afetivo é dado pela paixão da cólera: 
...e que em um vaso tão estreito e tão sensitivo como o coração humano, hajam de caber juntas, e estar em paz todas estas contrariedades? Alma, corpo, que dizeis a este preceito? Ajunte-se a república interior e exterior do homem, chame a cortes ou a conselho todas suas potências, todos seus sentidos, e sejam ouvidos nesta causa todos, pois toca a todos. Que é o que dizem? Todos repugnam, todos reclamam, todos se alteram, todos se unem e conjuram em ódio e ruína do inimigo. A memória, sem jamais se esquecer, representa o agravo; o entendimento pondera a ofensa; a fantasia afeia a injúria. A vontade implora, e impera a vingança. Salta o coração, bate o peito, mudam-se as cores, chamejam os olhos, desfazem-se os dentes, escuma a boca, morde-se a língua, arde a cólera, ferve o sangue, fumegam os espíritos; os pés, as mãos, os braços, tudo é ira, tudo fogo, tudo veneno (Vieira, 1993, Vol. I, p. 720).

Sobre a mesma temática (amar o inimigo), encontramos o "Sermão da Primeira Quarta-Feira da Quaresma" de 1651. No exórdio (primeira parte do sermão) ao fazer a retomada de outros sermões quaresmais que antecederam esta prédica, está a evidência da dinâmica anímica. Padre Vieira, propõe que se chegue a Deus "com toda a alma”, e indica as potências memória, entendimento e vontade:

Que depressa nos leva a Igreja a Deus, e com toda a alma! Anteontem nos excitou a memória, ontem nos ilustrou o entendimento, hoje nos aperfeiçoa a vontade. Excitou-nos a memória com a lembrança da morte: Memento homo quia pulvis es; ilustrou-nos o entendimento com o maior exemplo da fé: Non inveni tantam fidem in Israel; aperfeiçoa-nos a vontade com o ato mais heróico da caridade, que é o amor dos inimigos: Diligite inimicos vestros (Vieira, 1993, Vol. I, p. 753)

Em outro sermão (Sermão na Segunda-Feira depois da Segunda Dominga da Quaresma de 1652), ao desenvolver o argumento sobre como seria duvidoso o arrependimento e conversão na hora da morte, o orador toma novamente $\mathrm{o}$ funcionamento da alma como tema. O homem totalmente imerso na realidade, no sentido de estar à mercê de suas contingências no mundo, não é sempre "senhor de si", apesar de possuidor de potências e dos sentidos e sentimentos, pode passar de sujeito a sujeitado, alienando-se de si:

A memória perdida, o entendimento sem juízo, a vontade atônita e pasma: os sentidos todos só vivos para a dor, e para o mais já quase mortos: a alma na garganta, e a respiração agonizante. Oh que transe tão apertado! [...] E nesta perturbação, nesta confusão, neste labirinto de cuidados e afectos (tão implicados os deste mundo com o do outro) como poderá dar todo o coração a Deus, nem oferecer-Lho como seu, que por dividido e alienado totalmente, já não é senhor de si, nem possui dele a mínima parte? (Vieira, 1993, Vol. I, p. 969). 
No sermão da Epifania de 1662, o pregador também se remete ao modelo psíquico para explicitar à corte portuguesa a grande dificuldade de acomodar a fala e os ensinamentos dos missionários aos índios no Maranhão:

...é necessário, finalmente, gemer, gemer com toda a alma; gemer com o entendimento, porque em tanta escuridade não vê saída; gemer com a memória, por que em tanta variedade não acha firmeza; e gemer até com a vontade, por constante que seja, porque no aperto de tantas dificuldades desfalece e quase desmaia (Vieira, 1993, Vol. I, p. 434, 435).

Em um sermão do tempo litúrgico do Advento (Primeira Dominga) Vieira apresenta Cristo inquirindo ao homem, para que este preste conta das muitas dádivas recebidas em sua criação. Ao falar da alma do homem em seus ornamentos e dos elementos que podem ser produzidos nesta alma, a qual o homem deverá dar conta a Deus, Vieira a descreve também segundo características que parecem ser inspirados na doutrina aristotélico-tomista:

[...] dei-te uma alma tirada de minhas entranhas, e feita à minha imagem e semelhança; ornei, e habilitei um e outro, com as mais excelentes potências, e os mais nobres sentidos, para que fossem os instrumentos com que me servisses e amasses; e tu ingrato, que fizeste? Dá conta dos cuidados, pensamentos e máquinas do teu entendimento; das lembranças e esquecimentos da tua memória; dos desejos e afeições da tua vontade. Dá conta de todos os passos de teus pés, de todas as obras de tuas mãos, de todas as vistas dos teus olhos, de todas as atenções dos teus ouvidos, de todas as palavras de tua língua, e de tudo o mais que tu sabes, e não cabe em palavras (Vieira, 1993, Vol. I, p. 219).

\subsection{Imaginação}

A persuasão retórica é pensada e construída dentro de um referencial imagético (TESAURO, 1965). A partir do conhecimento do dinamismo psíquico o pregador deve ser capaz de fazer emergir imagens na alma de seus ouvintes através do falar, da palavra. No jogo da linguagem, metáforas, exemplos e analogias criam, evocam, ou redimensionam (re-significam) figuras, as quais são aprazíveis ou repulsivas aos apetites, ao mesmo tempo em que facilitam o entendimento.

Toda a pedagogia jesuítica é orientada a partir da potência imaginativa. Tem-se nos Exercícios Espirituais de Inácio de Loyola (2002) um programa que busca ordenar os afetos e outras instâncias da alma (buscando justapor alvedrio humano e Graça divina), tendo na imaginação um enfoque preponderante. $\mathrm{O}$ uso ativo da imaginação 
(bem como da memória) é o que estrutura as quatro semanas dos "Exercícios Espirituais". A imaginação é solicitada para a criação de cenas, composições de lugares (compositio loci), apercepções sensoriais, reconstrução de fatos da memória ou conjecturas fabulosas. Tudo tem como objetivo mobilizar afetos de forma ordenada. Buscando-se através da imaginação os afetos próprios de cada exercício deve-se meditar cada ponto proposto com as três potencias: memória, entendimento e vontade (LOYOLA, 2002). Os sermões de Vieira parecem conciliar-se com a proposta dos Exercícios Espirituais (Loyola, 2002), tanto no modo de pensar a articulação das instâncias internas da alma, como na tentativa de proporcionar a seu ouvinte vivências e ordenações anímicas propícias a metanóia.

Vieira apresenta a imaginação como potência do homem que pode tanto representar acesso ao conhecimento, bem como apartamento da realidade, engano. Isso tudo, dada a capacidade inventiva que esta possui. No "Sermão da Segunda Dominga da Quaresma" de 1651, Vieira comenta o texto do apóstolo João onde este "fabrica" a cidade da glória. O pregador fala da descrição de João de uma rica e portentosa cidade, onde até as calçadas são feitas de ouro e pedrarias, indicando a tentativa de através da imagem de riqueza, passar a ideia da glória jamais vista:

E imaginando vós com o pensamento, podeis conceber e fabricar nele uma cidade tão grande como esta, edificada toda de ouro, de diamantes e pérolas? Não há dúvida que sem sermos grandes arquitetos, como Vitrúvio, a podemos imaginar e idear assim; e ainda mais a gosto de cada um (Vieira, 1993, Vol. I, p. 882, 883).

No mesmo sermão, Antônio Vieira comenta sobre a função pedagógica, das imagens. Compara os profetas aos matemáticos e astrólogos. Os profetas falariam sobre os mistérios e a glória do "Céu lá de cima", enquanto que os astrólogos, sobre "este céu cá de baixo". Ambos utilizam-se legitimamente de imagens e metáforas para transmitir conhecimento, fingem (fantasiariam) de maneira criativa tendo por fim instruir. Em metalinguagem o pregador fala sobre analogias e imagens para acessar o entendimento, utilizando-se ele mesmo deste processo:

Viram os matemáticos esse labirinto de luzes, de que está semeada sem ordem toda a esfera celeste, tão diversas na grandeza, como várias no movimento e infinitas no número; e para assentar alguma coisa certa em uma confusão tão imensa, que fizeram? Repartiram o mesmo céu, e fingiram em todo ele grande multidão de figuras, umas naturais, outras fabulosas [...] Pois, no céu há estes animais, estas fábulas, estes monstros? Não, que tudo são estrelas resplandecentes e formosas. Mas foi necessário aos matemáticos fingir no céu estas mentiras e pôr lá estas fábulas, para, por meio delas, se entenderem 
entre si e ensinarem de algum modo ao mundo a verdade do que passa no céu (Vieira, 1993, Vol. I, p. 888, 889).

Em um trecho do "Sermão da Primeira Sexta-Feira da Quaresma" de 1644, ao discutir o possível aborrecimento que o amor causa, escreve: "e a estar ou andar sempre penando fora de si, por uma imaginação fantástica do que não há nem é, nem o nome de loucura e cegueira basta a declarar o desvario de tão custoso engano" (Vieira, 1993, Vol. I. p. 710,711).

A imaginação aparece associada ao engano, desvinculando o sujeito da realidade e fazendo-o perder o governo de si, destituindo-o da razão e sujeitando a vontade. No "Sermão do Mandato" de 1645, referendando-se em uma passagem do Antigo Testamento é retomada a figura de Jacob, o qual trabalha durante sete anos para Labão em troca de casar-se com sua filha mais jovem, Raquel, mas Labão concede-lhe ao final a outra filha, Lia:

Serviu logo ao engano, e não ao amor, porque serviu por quem não amava. Oh quantas vezes se representa esta história no teatro do coração humano, e não com diversas figuras, senão na mesma! A mesma que na imaginação é Raquel, na realidade é Lia: e não é Labão o que engana a Jacob, senão Jacob o que se engana a si mesmo (Vieira, 1993, Vol. II, p. 338).

Ainda no contexto do discurso sobre o amor, no "Sermão Da Primeira SextaFeira da Quaresma" de 1644, escreve: "É quimera, é mentira, é engano, é uma doença da imaginação, e por isso basta para ser tormento" (Vieira, 1993, Vol. I, p. 713). Ou seja, a argumentação para desacreditar o amor (Eros) seria a capacidade deste causar o adoecimento da imaginação, de modo que esta produz fabulação e não conhecimento. $O$ homem ficaria destituído de juízo. A imaginação tomará de maneira indevida campos de atuação que caberiam à razão e a vontade. Tal desequilíbrio, segundo Vieira, causara tormento. O autor diz em outra oportunidade (Sermão da Quarta Dominga do Advento) que o homem destituído da razão e com a vontade submetida às paixões, descaracteriza sua humanidade. É como que um bruto, animalizado ou reificado (transformado em coisa), um ser com a potência da razão, mas destituído dela.

Vieira explicita o lugar da imaginação na arquitetura da alma humana. No "Sermão do Demônio Mudo" de 1661, o jesuíta elabora uma descrição do funcionamento do dinamismo psíquico em sua capacidade de conhecer ou enganar-se via imaginação. Aqui é apresentada uma descrição da potência imaginativa e seu modo de atuar: 
Dentro da nossa fantasia, ou potência imaginativa, que reside no cérebro, estão guardadas, como em tesouro secreto, as imagens de todas as cousas que nos entraram pelos sentidos, a que os filósofos chamam espécies. E assim como nós das letras do á-bê-cê, que são sòmente vinte $\mathrm{e}$ duas, trocando-as e ajuntando-as vàriamente, escrevemos e damos a entender o que queremos; assim o Demónio daquelas espécies, que são infinitas, ordenando-as, e compondo-as como mais lhe serve, pinta e representa interiormente à nossa imaginação, o que mais pode inclinar, afeiçoar, e atrair o apetite. E deste modo mudamente nos tenta, mudamente nos persuade, e mudamente nos engana. Isto mesmo é o que passa entre a vista e o espelho, e tanto mais viva e enganosamente, quanto é maior o desejo de bem parecer. Saem as espécies direitamente do rosto ao espelho, e recebidas no vidro e rebatidas do aço, tornam reflexamente aos olhos; e nesta ida e volta, ambas mudas e em silêncio, por engano do amorpróprio, se pinta ou despinta de tal sorte o mesmo objecto, que mais parece milagre da transfiguração, que ilusão da vista (Vieira, 1993, Vol. I, p. 1173).

A "tentação demoníaca", se assim a podemos definir, se daria por via do “aparelho psíquico". A percepção (interna) é distorcida, a partir de um desejo orientado pelo amor-próprio (narcisismo, anacronicamente). É a partir da maneira como a imaginação atua que são movidos os demais elementos da alma. Pode-se imaginar uma analogia com a lógica: uma grande sequência de silogismos perfeitamente encadeados, onde a primeira premissa do silogismo inicial é falsa. Sendo a premissa falsa, o raciocínio lógico é perfeito, mas a conclusão não é verdadeira. Dada a constituição fabulosa da imaginação, apesar de o dinamismo psíquico funcionar ordenadamente, há uma distorção na percepção da realidade.

Assim, o engano do "demônio mudo" age, tirando a real imagem das coisas do mundo e colocando em seu lugar a ilusão (fabulação) que fomenta os apetites, onde a vontade sucumbe ao desejo. Essa organização própria dos sentidos internos, que persuade silenciosamente enganando, é combatida com a palavra laboriosa (que desengana), restituindo-se à vontade a regência política dos afetos.

Na dinâmica da alma, a imaginação tem também o papel de espiritualizar os dados sensíveis e articular as apreensões das demais potências. As espécies captadas pelos sentidos externos e articuladas pelas potências sensitivas são conduzidas, via imaginação, ao espírito. A porta para se adentrar ao espírito é a imaginação:

O átrio ou pórtico da alma é a fantasia, onde as espécies corporais se espiritualizam, e dali sobem ao entendimento que as representa à vontade; e para que não cheguem, nem entrem lá os maus pensamentos, ponha-se à porta do mesmo átrio um porteiro, o qual se chama, recordatio propriae professionis, lembrança da própria profissão (Vieira, 1993, Vol. V, p. 118) 
Aqui, como argumento, resgata-se a profissão religiosa ${ }^{19}$ de Francisco Xavier em um sermão dedicado a este jesuíta. O sermão propõe um elogio a Xavier, por resistir às tentações, mesmo em sonho.

Tal qual a imaginação intervém na alma racional, esta pode orientar a atividade da imaginação. A reminiscência orientada pela razão é aparato que pode ordenar a fábrica da imaginação. Na passagem, Xavier trazia ao peito uma peça em bronze contendo relíquias e os dizeres de sua profissão. Uma interpretação possível que fizemos é que existe um meio de intervir na imaginação por meio da memória. $\mathrm{O}$ fazer memória de quem se é e o que se quer, é uma forma de intervir na potência imaginativa, com o propósito de fabricar pensamentos na mente que sejam condizentes com a memória feita.

Nos "Exercícios Espirituais" de Loyola (2002), fala-se do discernimento dos espíritos: o próprio, o do bem e o do mal. Tal ideia corresponde à dinâmica do eu humano em sua tensão existencial entre dois mundos, o divino e o antidivino (LOYOLA, 2002). São os espíritos que insuflam os pensamentos. Escreve Vieira no "Sermão de Santo Inácio, fundador da Companhia de Jesus" de 1669: "Jazia Dom Inácio de Loyola malferido de uma bala francesa no sítio de Pamplona; e picado como valente de ter perdido um castelo, fabricava no pensamento outros castelos maiores, pelas medidas de seus espíritos.” (VIEIRA, 1993, Vol. III, p. 417-418). Entretanto, como se sugere nos excertos anteriores, a fabricação dos pensamentos se da pela imaginação. Aparentemente, através do "psiquismo", na faculdade imaginativa, está a apreensão e comunicação da realidade natural e sobrenatural ao homem. As espécies originadas do meio são comunicadas e representadas à imaginação; os espíritos, próprio, do bem e do mal, manifestam-se no "psiquismo", operando na potência imaginativa.

Ainda dentro da descrição da arquitetura da alma, o jesuíta retoma o papel da potência imaginativa nos sermões referentes aos sonhos de Xavier (Vieira, 1993, Vol.). $\mathrm{Na}$ descrição onírica, segundo a tradição (Vieira cita Aristóteles, retomando-o), o religioso descreve novamente a fantasia.

"Um dos maiores mistérios e mais delicados segredos da natureza na arquitetura humana é a fábrica dos sonhos. Sendo o sono uma prisão universal dos sentidos, com que os olhos não vêem nem os ouvidos ouvem e assim dos demais; como pode ser que sonhando vemos sem ver, e ouvimos sem ouvir, e exercitamos os actos dos outros sentidos

\footnotetext{
${ }^{19}$ Prática da Vida Religiosa católica na qual uma pessoa faz votos de pobreza castidade e obediência, consagrando sua vida a Deus a serviço da Igreja.
} 
E ainda:

como se estiveram espertos? A razão ou filosofia deste artifício natural é, porque na memória (não a espiritual, que é potência da alma, senão a corporal e sensitiva) estão depositadas as espécies de todos os objectos, ou as imagens de todas as cousas que entram pelos sentidos. Estas imagens, enquanto os sentidos dormem, estão encobertas e escondidas debaixo dos vapores grossos e espesso que sobem ao cérebro; e ao passo que os mesmos vapores se vão adelgaçando e desfazendo, as imagens aliviadas deles se vão também descobrindo e representando à fantasia, que por outro nome se chama imaginativa e é a potência com que imaginamos" (VIEIRA, 1993, Vol. V.p. 79).

Aristóteles, explicando como se formam os sonhos, diz assim: Horum autem unumquodque est relíquia ejus, quod est in actu sensibili. Os sonhos são relíquias daqueles actos que pelas espécies recebidas dos sentidos se formaram na imaginação. Estes actos deixaram impressas na imaginação umas relíquias muito subtis, representadoras dos seus objectos; e quando estas relíquias se movem e aparecem, elas são as que representam, compõem e fabricam os sonhos. De maneira que os sonhos não são outra cousa, senão as relíquias dos cuidados (VIEIRA, 1993, Vol. II, p. 45).

O que se vê é uma recapitulação de uma longa tradição sobejando através da obra do autor. Isto não apenas para o exemplo onírico, mas em todas as ideias apresentadas. O fenômeno imaginativo, sua capacidade criativa, inventiva são investigados há tempos na história. $\mathrm{Na}$ obra de Vieira podemos colher alguns dos pensamentos que se desenvolveram por volta do tema, segundo a roupagem dada pelo inaciano.

Assim sendo, entendemos que a imaginação é uma temática que se apresenta em diversos aspectos nos sermões. Apresenta-se, por exemplo, vinculada a estrutura argumentativa erigida pela retórica. O uso de imagens é lugar comum na prédica da época de Vieira (MASSIMI, 2005). Por meio de metáforas, exemplos e descrições procura-se facilitar a compreensão do ouvinte e persuadi-lo. Há também uma teoria do funcionamento anímico, portanto da imaginação, que fundamenta a prática da pregação. Outro aspecto é o papel da imaginação enquanto suporte para produção do conhecimento. A capacidade de fantasiar, de fazer abstrações da realidade presente, é pressuposto para a atuação do entendimento. Do mesmo modo, a imaginação pode produzir fantasias que distanciam o homem da verdade. Por todos estes elementos, entendemos que a imaginação tem papel de destaque junto aos sermões, tanto no que diz respeito à produção do sermão enquanto gênero discursivo (e literário), bem como prática social inserida no contexto do século XVII e sua visão de mundo. 


\subsection{Memória}

Em Vieira o termo memória é amplamente utilizado. A memória é da ordem da ontologia do homem, constitui seu ser e junto a entendimento e vontade estabelece sua identificação com o divino. Escreve o inaciano no "Sermão da Dominga Vigésima Segunda Depois de Pentecostes": "Resolvem pois todos os santos e doutores católicos, que a razão da imagem de Deus no homem consiste na alma adornada de três potências, em que representa ao mesmo Deus trino, e um" (Vieira, 1993, Vol. II, p. 1159). Essa relação trinitária (memória/entendimento/vontade) assume valor epistemológico e contemplativo/revelativo. A maneira pela qual o homem conhece passa pelo corpo, sentidos e potências, suas percepções e apercepções. Porém, dentro de uma teleologia, busca-se juízo, deliberação e ação (obra). Ou seja, o corpo torna-se meio através do qual o homem deve conhecer a realidade e agir nela. $\mathrm{O}$ ápice deste processo parece estar na relação (que carrega especificidade e complementaridade) entre memória, entendimento e vontade, a qual arrasta consigo as demais instâncias da alma. Em um excerto representativo do papel das potências é trazida no "Sermão de dia de Ramos" de 1656, a cena evangélica da agonia no horto e a figura prototípica e exemplar de Jesus:

Oh quem pudesse entrar profundamente no interior da alma de Jesus, e
entender o que naquele consistório sacratíssimo e secretíssimo das
suas três potências passava e se conferia em tantas horas! A memória,
desde o princípio do mundo representava os pecados de todos os
homens, por que satisfazia à divina justiça: o entendimento ponderava
o pouco número dos mesmos homens que se haviam de aproveitar do
preço infinito daqueles tormentos: e a vontade se desfazia com dor, de
ver perder tantas almas por sua culpa, sem achar consolação alguma a
tamanha perda: e esta era a tristeza que ocupava toda a alma do
Salvador, e com três cravos mais agudos e penetrantes a crucificava
(VIEIRA, 1993, Vol. II, p. 284 )

Do mesmo modo, Vieira retoma as três potências ao falar do Rosário (Sermão de Nossa Senhora do Rosário de 1654), aproximando a nutrição do corpo e nutrição da alma. A utilização de metáforas sobre alimentação é comum na pregação da Idade Moderna, sendo amplamente utilizadas por Vieira (MASSIMI, 2006). O religioso descreve um "metabolismo espiritual" (MASSIMI, 2006), onde as potências da alma devem digerir os mistérios do Rosário. Em um movimento contemplativo das potências se estabelece conhecimento, desvela-se uma verdade, modela-se um comportamento:

“Aristóteles e Galeno, descrevendo a fábrica da nutrição, para a qual formou a natureza várias oficinas e instrumentos, reduzem toda a operação deles as três potências principais, uma que recebendo retém, outra que alterando assemelha, outra que unindo converte. E tudo isto 
obra o Rosário por meio das três potências de nossa alma nos mistérios da vida, morte e paixão de Cristo, de que ele se compõe, e não só em todos, senão em cada um. Com a potência da memória recebe e retém o mistério por meio da apreensão: com a potência do entendimento altera-o e assemelha-o a si (ou a si a ele) por meio da meditação: e com a potência da vontade converteu e uniu em si mesma por meio da imitação" (VIEIRA, 1993, Vol. IV, p. 788)

O mesmo uso de metáforas alimentares é utilizado referindo-se à eucaristia. Em outra passagem do mesmo sermão, Vieira dá destaque à potência memorativa. Esta seria o "estômago da alma":

E porque fez menção o Senhor somente da memória? Porventura porque excluiu as outras potências? Não; mas porque é aquela em que se faz a primeira decocção deste soberano manjar. Já S. Pedro Damião nos disse, que ele se recebe com grande suavidade no estômago da nossa alma: Haec epulae mentis nostrae stomachum suaviter replent. E qual é o estômago da alma? Santo Agostinho, excelente filósofo da memória no-lo ensinou, e já antes dele o tinha definido Platão: Memoria est animae ventriculus. $\mathrm{O}$ estômago da alma é a memória; porque assim como no estômago do corpo se recebe e retém o comer corporal, e ali se faz a primeira decocção, assim esta potência é a primeira que há-de receber e recolher dentro em si o divino Sacramento, lembrando-se não de passagem, senão muito devagar (como se faz no corpo) e representando à alma que é o que está presente naquele mistério, e os mistérios altíssimos que nele se encerram. E porque os acidentes sacramentais nos encobrem a ausentam dos olhos a presença de Cristo; a memória cuja propriedade é fazer presentes as cousas ausente, no-lo há-de fazer presente (VIEIRA, 1993, Vol. IV, p. 789).

Assim, a memória seria o lugar de guardar as imagens recebidas e "processadas", bem como impressões, ideias, juízos, fornecendo matéria-prima para grande parte dos outros processos da alma ocorrerem.

Uma interessante descrição do funcionamento da memória é dada no "Sermão das Quarenta horas" pregado por Vieira em 1642. Ao argumentar sobre a teoria de como percebemos a consonância, ou dissonância do que ouvimos, padre Vieira quer provar que o tempo é o melhor intérprete das profecias, matéria do sermão. A correspondência do profetizado com o ocorrido e confirmado no tempo é consonante. $\mathrm{O}$ passado gentílico e o presente cristão formam a dissonância. Nos interstícios da argumentação, colhemos nossos dados:

A filosofia da consonância e dissonância ainda em uma só palavra, ou sílaba, é tão admirável, como pouco advertida. Sendo a consonância, concórdia do som, e a dissonância, discórdia; e sendo o som um movimento sucessivo, que perde uma parte, quando adquire outras; é certo que quando a parte que soa e existe no ouvido, se ouve, a parte que passou já não se ouve, porque já não existe, nem soa: como pode logo ser, que do que se ouve, e do que se não ouve se forme a 
consonância ou dissonância? O como, ou modo natural desta filosofia, é, que a parte do som que passou, ainda que já não soa, nem existe no ouvido, existe, porém, e persevera na memória: e da parte do som passado, que persevera na memória, junta com a parte do som presente, que continua no ouvido, resulta entre o ouvido e a memória a consonância ou dissonância das vozes. Troquemos agora os sentidos, e do ouvir passemos ao ver, e entre os olhos e a memória veremos no nosso caso a mesma maravilha. Ponha-se neste formoso teatro a memória de fronte da vista, e a vista de fronte da memória; e na contraposição destes dois espelhos se verá a consonância maravilhosa do tema, isto é, da profecia com o profetizado, e a dissonância ainda mais admirável dos tempos, isto é, do passado com o presente. $\mathrm{O}$ passado tão descomposto, o presente tão modesto: o passado tão disforme, o presente tão reformado: o passado tão abominável, o presente tão louvável: o passado tão gentílico, o presente tão cristão: o passado tão ímpio, e o presente tão santo (VIEIRA, 1993, Vol. I, p. 547).

Vieira ao discorrer sobre a "filosofia da consonância e dissonância" descreve tanto o funcionamento da memória quanto a interação entre memória e imaginação. No excerto, Vieira parte da percepção sonora. Para se perceber a consonância ou dissonância de um som torna-se necessário uma comparação entre o existente e o não mais existente. Ou seja, o som que se houve agora comparar-se-á a outro que se perdeu no tempo-espaço. Então a comparação só é possível de ser feita mediante uma reatualização do fenômeno percebido. Deste modo, pode-se perceber a ação da memória. A potência memorativa resgata em seu bojo o fantasma do som captado - sua representação destituída das noções de tempo e espaço. Ou seja, reaviva a espécie sensível captada inicialmente através do sentido próprio da audição. A espécie sensível colhida pela imaginação e guardada na memória é novamente restituída à imaginação. Orientada pela razão, a memória poderia buscar em seu arquivo a devida reminiscência para termo de comparação. Assim, neste teatro atuam no mesmo palco imaginação e memória. Presente e passado podem se relacionar principalmente graças a estas duas potências. Desta maneira, se pode estabelecer um juízo, um entendimento - dissonância ou concordância -, no nível do intelecto. Nível final para qual todo processo persuasivo se orienta, escreve o inaciano no "Sermão da Sexagésima": "O pregar, não é recitar. As razões próprias nascem do entendimento, as alheias vão pegadas à memória, e os homens não se convencem pela memória, senão pelo entendimento" (VIEIRA, 1993, Vol. I, p. 93).

Destarte, sem entendimento a memória tem dificuldade de se orientar e organizar suas reminiscências. Vieira fala no "Sermão da Epifania" de 1662 à corte portuguesa da dificuldade de lidar com os nativos do Brasil com pretensa limitação 
intelectual ou dificuldade de compreensão: “... e a ensinar o já ensinado, e a repetir o já aprendido, porque o bárbaro boçal e rude, o tapuia cerrado e bruto, como não faz inteiro entendimento, não imprime nem retém na memória” (VIEIRA, 1993, Vol. I, p. 437).

No "Sermão do Demônio mudo", que já apresentamos relacionado à faculdade da imaginação, o argumento do espelhamento, da maneira como traz Vieira, se constitui como um dado interessante para o estudo memória. O espelho, como objeto e metáfora, é o principal tópico deste sermão. Vieira argumenta que, através do espelho, o homem contempla a si mesmo em detrimento de contemplar a Deus. Erro tão natural (do qual os espelhos podem ser cúmplices) que até mesmo "um espírito de tão sublime entendimento" como Lúcifer incorreu: "Foi vendo Lúcifer sua extremada formosura, ficou tão satisfeito dela, que renunciou a vista de Deus, não quis outra mais que a sua" (VIEIRA, 1993, Vol. I, p. 1175). Ao arguir sobre a dificuldade de se abrir mão do espelho, o pregador recorre à psicologia filosófica para desenvolver seu argumento:

\begin{abstract}
Vê um homem aos outros, e lembra-se claramente das feições do rosto e figura de cada um, e ausente o retrata na imaginação assim como o viu; mas se viu no espelho a si mesmo, logo se esquece, nem se pode pintar, ou figurar como é. E donde vem, ou se causa esta diferença tão notável: vem do diferente modo com que vemos as cousas no espelho, ou em si mesmas. Em si mesmas vemo-las por espécies directas, que são mais vivas, e mais fortes; no espelho vemo-las por espécies reflexas, que não têm aquela vida, ou aquela viveza, nem aquela força. E a razão é, porque o reflexo que as rebate no espelho, as enfraquece de tal sorte, que quando chegam à potência, onde se formam as espécies memorativas, por meio das quais nos lembramos, ou estas se não produzem, ou são tão ténues, e quase mortas, que se não pode servir delas a memória, e se segue naturalmente o esquecimento. Logo quem sacrifica o espelho, não só renuncia nele a vista futura, senão também a passada. A futura, porque se não há-de ver, pois não tem espelho: a passada, porque por falta do mesmo espelho não pode renovar na memória, nem suprir no esquecimento o retrato de quando se viu: Et oblitus est, qualis fuerit (VIEIRA, 1993, Vol. I, p. 1181, 1182).
\end{abstract}

A descrição do funcionamento anímico, onde imaginação, espécies e memória interagem, remete a uma apropriação direta dos Conimbricenses no que diz respeito a doutrina sobre os sentidos internos da alma e espécies impressas e expressas (ZANLONGHI, 2003). Notamos a estreita ligação entre imaginação e memória. A imagem (espécie) que não é apropriadamente retida se perde. A própria imaginação é incapaz de retomá-la, pois isto não lhe cabe: "renuncia a vista passada".

O homem não é capaz de reter mnemonicamente sua auto-imagem através da vista, por meio dos espelhos. Vieira engenhosamente vai trasladando o objeto, espelho, 
em metáfora. Assim, o único espelho no qual o homem poderia se ver seria suas obras, seu memorial, o qual é resgatado por meio de suas reminiscências. Propõem-se o uso da memória orientado pela razão. Faz-se uma busca e reconstrução ordenada das ações passadas, utilizando os conhecimentos adquiridos para estabelecer um juízo sobre si, elaborando a autoimagem, então poder ver-se a si mesmo, desenganar-se e converter-se:

Finalmente, vindo às obras, diz assim o santo legislador: Singulis diebus capitulum sibi teneat, et ponat rationem diligenter, quid ipso die publice, vel privatin: Todos os dias diante deste espelho faça a religiosa capítulo de si mesma, e chamando a juízo todas as suas potências e sentido, peça conta à sua consciência do que no mesmo dia tiver delinquiido. Examine e pergunte à memória, o de que se lembrou; ao entendimento, que cuidou; à vontade, o que amou ou aborreceu; aos olhos, o que viram; aos ouvidos, o que ouviram; e às outras partes, o que por elas entrou ou saiu (VIEIRA, 1993, Vol. I, p. 1192).

É recorrente em Vieira a ideia da memória não só como um sentido interno, mas também como função ética e de autoconhecimento. Torna-se necessário fazer memória das coisas. O resgate de uma reminiscência, orientado pela razão, constitui-se em valor moral quando direcionado para o presente. O conhecimento de si se dá pelas reminiscências adquiridas: o que se faz (obras) e o que se sente lá estão.

Recapitular na memória as vivências passadas pode orientar a ação no presente. O descuido dos homens em relação ao tempo parece ser um dos grandes enganos que Vieira pretende desfazer. Segundo o jesuíta, os homens não se dão conta de sua finitude, de que são apenas figuras que compõem uma breve cena no teatro do mundo. Vivem pensando que podem permanecer como o mundo permanece. Não se dando conta de sua finitude e de seu lugar no mundo e na criação, o homem põe em risco sua salvação. Falta-lhe memória do efêmero de que consistem as coisas do mundo; esquece-se de seu lugar na criação e seu lugar (deveres/afazeres/obras) no mundo. Portanto, entrega-se à vontade aliciada pela fantasia. Neste sentido destacamos o seguinte fragmento do "Sermão na Segunda-Feira depois da Segunda Dominga da Quaresma" de 1652:

Pois sabei que quando Deus assim deixa estas miseráveis almas, então ficam elas mais contentes e satisfeitas, porque como não tratam mais que do presente, sem memória do passado, nem temor do futuro, e como Deus que as pretendia sarar, já nenhum remédio lhes aplica, e nenhum apetite lhes veda, deixadas à natureza, vivem à sua vontade. Assim o diz o mesmo Deus: Dimisi eos secundum desideria cordis eorum, ibunt in adiventionibus suis. Quando me apartei totalmente, e deixei para sempre os que me deixaram, dei-lhes liberdade e largueza para que vivessem ao sabor dos seus desejos, com que esse pouco caminho que lhes resta, o andam todos, e cada um segundo as invenções de sua própria fantasia (VIEIRA, 1993, Vol. I, p. 953). 
Neste sermão, Vieira afirma que é o homem o primeiro a deixar Deus e só então, Deus o deixaria. Obras (passado) e juízo final (futuro) não teriam valor para o homem sem Deus, condenando o pensamento a uma espécie de presentismo irracional.

Sem memória não há o devido juízo das coisas, não há a possibilidade de síntese, o entendimento não opera devidamente, não havendo também temor (na acepção cristã, não entendido apenas como sentimento de medo, mas respeito e juízo). Não ha ação pensando criticamente nas consequências, pois o entendimento se torna circunstancial, escreve o pregador no "Sermão Da Terceira Quarta-Feira Da Quaresma" de 1669:

Anteontem nada, ontem barro, hoje homem, amanhã Deus? Não se lembrará Adão do que era ontem, e muito mais do que era anteontem? [...] Malcriados, e maus criados. Por isso descontentes e ingratos, quando deveriam estar mui contentes e mui agradecidos. E a razão desta sem-razão é porque dos sentidos perderam a vista, e das potências a memória; nem olham para o que são, nem se lembram do que foram (VIEIRA, 1993, Vol. II, p. 1097).

Através da memória pode-se conhecer a si mesmo, como já estabelecido por Agostinho nas "Confissões” (AGOSTINHO, 1997), bem como converter o próximo. No "Sermão de Quarta-Feira de Cinza" de 1673, Vieira conta sobre a atitude de um rei (Carlos V) frente o pedido de um de seus soldados: "Entrou um soldado veterano a Carlos V, e pediu-lhe licença com um memorial, para deixar seu serviço e se retirar das armas" (VIEIRA, 1993, Vol. I, p. 621). O imperador admirado com o pedido do soldado rememora a atuação de seu súdito em suas campanhas. Devida à excelente atuação do soldado e considerando que o pedido de dispensa fosse movido por insatisfação, o governante propõe vantagens a este. $\mathrm{O}$ militar recusa as vantagens oferecidas e valoriza mais o tempo de retiro para "aparelhar a alma" antes de morrer. É o que observamos no trecho a seguir:

E que vos parece que faria o César neste caso? Concedeu enternecido a licença; retirou-se ao gabinete, tornou a ler o memorial do soldado, e despachou-se a si mesmo. Oh soldado mais valente, mais guerreiro, mais generoso, mais prudente, e mais soldado que eu! Tu até agora foste meu soldado, e eu teu capitão; desde este ponto tu serás meu capitão, e eu teu soldado; quero seguir tua bandeira (VIEIRA, 1993, Vol. I, p. 621).

Portanto, a memória é apresentada não só restritamente como sentido interno, mas também como um dos principais componentes do ser do homem. Seguindo a doutrina de Agostinho (1997), o inaciano apresenta a memória como elemento substancial para o autoconhecimento e para o conhecimento da realidade. É por meio da memória que a alma 
racional pode se orientar de modo ordenado. Também a imaginação vincula-se diretamente a ação da memória, onde a primeira sempre realizará seus processos apoiando-se significativamente na potência memorativa. Dentro do processo de persuasão, como dito pelo pregador, não se converte pela simples memória, mas pelo entendimento. No entanto, o entendimento para estabelecer qualquer juízo e apresenta-lo à vontade, deve buscar na memória os elementos que disporá na mente. 


\section{Capítulo III: A Imaginação e a Memória na antropologia de Vieira}

Pretendemos neste capítulo apresentar algumas ideias e saberes psicológicos que a nosso entender se relacionaram mais diretamente com os termos imaginação e memória. Os temas aqui elencados não têm a pretensão de esgotar a temática, ou mesmo circunscrevê-la por completo. Traremos aqui de algumas construções de sentido que nos pareceram pertinentes e dignas de nota, seja pela ocorrência que se dão na obra, seja pela estruturação mais elaborada dentro de um ou outro sermão. Exporemos e analisaremos, a seguir, os fragmentos (excertos) considerados por nós os mais didáticos e representativos.

\subsection{Sentidos externos Imaginação e Memória}

“... porque o sentimento deve julgar conforme as espécies dos sentidos, que são as portas de todo o conhecimento humano..." (VIEIRA, 1993, Vol. II, p. 1037)

Para a imaginação atuar, é necessário que lhe sejam fornecidos subsídios. Estes podem vir tanto através da potência memorativa, como dos sentidos externos. Digamos que, grosso modo, a percepção em nosso modelo de referência segue certa ordenação. Este dinamismo parte da natureza das coisas percebidas pelos sentidos externos, passa pelo senso comunis, onde ocorre a primeira unificação das informações sensíveis captadas, passando em seguida pela imaginação (ou fantasia), sendo por fim armazenada na memória. A imaginação pode tanto receber as percepções advindas dos sentidos externos, quanto trazer de volta da memória imagens (fantasmas) guardadas.

Loyola (2002) discute tanto na primeira quanto na segunda semana de seus "Exercícios Espirituais" sobre imaginação orante e imaginação contemplativa. Na segunda semana se expressa referindo-se aos "cinco sentidos da imaginação" (LOYOLA 2002, p. 57). A imaginação seria conduzida por um esforço da razão e da vontade a conceber cenas das escrituras e lugares sobrenaturais, fazendo-se presentes para o exercitante as realidades misteriosas e suas verdades. Neste sentido as espécies, ou fantasmas captados pelos sentidos externos e guardados pela potência memorativa, são atualizados pela imaginação. Sua retomada dentro dos "Exercícios Espirituais" não representa mero jogo lúdico da imaginação, há uma presentação (não no sentido de 
representar enquanto simulacro, mas de tornar algo realmente presente) da realidade que ordena os afetos e cativa o alvedrio. Vieira escreve:

Assim vê com os olhos interiores da alma, e assim contempla e considera os profundíssimos mistérios da vida, morte e ressurreição de Cristo, que naquele compêndio de maravilhas, não tanto da omnipotência, quanto da bondade divina estão pelo Sacramento ocultos, e pelo Rosário manifestos. E que alma haverá tão esquecida de seu aproveitamento espiritual, que vendo naquele divino espelho umas imagens tão diferentes da sua, não estranhe e aborreça a sua fealdade, e se procure assimilar a elas (VIEIRA, 1993, Vol. IV, p. 792).

Na sequência deste excerto, o jesuíta amplifica o argumento, demorando-se em uma efetiva composição de lugar tal qual os "Exercícios Espirituais" de Loyola (2002), compondo as cenas dos mistérios do Rosário e de passagens do Evangelho.

Igualmente, notamos nos sermões a crença de que os sentidos externos subsidiam as demais potências, portanto tendo grande importância para suscitar afetos, orientar o juízo e a deliberação do espírito. Vieira discute principalmente dois sentidos externos: visão e audição. Ver e ouvir são tópicos recorrentes nos sermões, mesmo porque são elementos básicos da comunicação utilizados na pregação. São apresentados em seu vínculo direto com a imaginação, ligados em última instância à esfera racional, influenciando vontade e intelecto de tal forma que os sentidos externos tocam a imaginação e, por conseguinte, esta orienta apetites e paixões que interferem diretamente na vontade. Nas palavras de Vieira:

\footnotetext{
"Assim como do mesmo homem se diz com verdade que vê e ouve; e com a mesma verdade que entende e ama; e não segue por isso que entende e ama pelos sentidos do corpo, nem que vê e ouve pelas potências da alma" (VIEIRA, 1993, Vol. IV p. 632).
}

São fontes de produção de conhecimento tanto quanto de engano e dispersão: "E como a alma, que na oração devia estar toda recolhida e dentro em si, abertas as portas dos sentidos, sai fora e se derrama e distrai com outros cuidados" (VIEIRA, 1993, Vol. IV, p. 863)

Proporcionam também o contato com o mundo natural de maneira positiva, saudável, e possibilitam seu desfrute ordenado de modo aprazível: "Para digerir o negócio, é necessário desafogar o ânimo: parte é logo de cuidado o divertir-se, quando o recrear os sentidos vem a ser habilitar as potências" (VIEIRA, 1993, Vol. IV, p. 1335). 
Os olhos, o olhar, o ver, a vista são termos recorrentes nos sermões e de modo geral prenhes de significado imagético e metafórico. O uso da visão tem como fim a produção da imagem. Tal imagem é ora evocada como espécie captada da realidade natural, ou como fantasma resgatado da memória e atualizado pela imaginação, ou ainda como acuidade intelectual ou espiritual (revelação) em um dar-se conta da realidade (natural ou transcendente). A dupla visão/cegueira aparece com frequencia fazendo referência a conhecimento/engano. Há a busca de uma verdade (muitas vezes velada e misteriosa) e a produção de uma ética (atravessada por um desengano). A verdade deve ser demonstrada, desvelada, vista, ou seja, reconhecida, gerando apreensão de uma correspondência. Portanto, é grande o valor atribuído às obras e à figura do pregador. No fragmento a seguir, observamos um exemplo, de como as obras atestam a verdade por meio da vista:

Sabem, padres pregadores, porque fazem pouco abalo os nossos sermões? Porque não pregamos aos olhos, pregamos só aos ouvidos. Porque convertia o Batista tantos pecadores? Porque assim como as suas palavras pregavam aos ouvidos, o seu exemplo pregava aos olhos" (VIEIRA, 1993, Vol. IV, p. 84)

Enquanto estrutura da alma, os olhos veem pelo coração e falam ao espírito. $\mathrm{O}$ tônus afetivo são as lentes que corrigem ou distorcem a visão, perpassando esta pelas potências e se apresentando ao entendimento e a vontade. Tudo começa por uma vista:

\footnotetext{
"Que paguem os olhos os pecados dos olhos; que paguem os olhos chorando, o que os olhos pecaram vendo, castigo é muito justo, e justiça muito igual: mas que os olhos hajam de pagar pelos pecados de todas as potências da alma, e pelos pecados de todos os sentidos, e membros do corpo; que justiça e que igualdade é essa? [...] se peca nos maus pensamentos, pague a memória; se peca nos maus juízos, pague o entendimento; se peca nos maus desejos, e nos maus afectos, pague a vontade: mas que os tristes olhos hajam de pagar tudo, e por todos? [...] Pecou a alma os olhos são os culpados [...] Pecou o corpo os olhos são os delinquentes [...] Todos os pecados do homem, os de pensamento, os de palavra, os de obra, saem imediatamente do coração. [...] E para todos os pecados, a quem segue o coração? Aos olhos [...] Se vos cegais e vos deixais arrebatar e enfurecer pela paixão, os vossos olhos são os apaixonados..." (VIEIRA, 1993, Vol. IV, p. 574-575)
}

Vieira fala da visão ao comentar do cego no evangelho que recupera a vista no “1 Sermão Da Quinta Quarta-Feira da Quaresma” de 1669. O cego vendo pela primeira vez, compara os homens a árvores que andam, sendo necessária uma segunda intercessão de Cristo para que este veja corretamente:

Quando as via (as coisas) estava muito mais cego, porque quando não via nada tinha privação da vista; quando via as coisas às avessas, tinha erro na vista, e muito maior cegueira é o erro que a privação. A 
privação era um defeito inocente, que não mentia nem enganava; o erro era uma mentira com aparência de verdade, era um engano com representação de certeza, era um falso testemunho com assinado de vista [...]. É filosofia bem-fundada de Filo Hebreu que os olhos não só vêem a cor, senão a cor, a figura e o movimento, e em todas estas três coisas errou a primeira vista daquele homem, representando-lhe os homens como árvores (VIEIRA, 1993, Vol. II, p. 107).

Vieira quer discutir com este argumento um tipo de cegueira muito peculiar, que consiste não da falta da vista, mas de uma distorção dela. Seu intento no sermão é acusar os fariseus de verem as avessas, ou seja, não se darem conta do dado de realidade que se apresenta - no caso a divindade de Cristo. Consequentemente, condena uma postura humana na qual se abre mão do dado de realidade percebido em favor de um juízo preconcebido. Mas, o que nos interessa particularmente no excerto é a escolha que o orador faz para desenvolver o argumento. Vieira discute o que é "ver", com base na tradição filosófica. Afirma que não é o bastante a captação das imagens (ou espécies), sendo necessária uma devida organização e categorização delas. Deste modo, a vista que em última instância atesta a realidade pode ser fonte de engano. Portanto, ao deixar de produzir um conhecimento verdadeiro, perde sua função tornando-se assim uma modalidade de cegueira.

Em uma passagem de outro sermão, Vieira argui sobre a dificuldade de se abrir mão de olhar-se no espelho. Os olhos são espelhos naturais, onde quem olha nos olhos alheios pode ver-se em figura diminuta - as meninas. Já os espelhos serviriam como olhos fabricados pela engenhosidade humana, para superar uma limitação da visão: a impossibilidade de quem olha ver-se a si próprio pelos mesmos olhos. O interessante de se notar é que para fundamentar sua observação cita explicitamente os tratados Conimbricenses de maneira elogiosa no "Sermão do demônio Mudo":

... quem renuncia, o ver-se no espelho, não só sacrifica a vista, senão também os olhos com que se vê. Funda-se esta proposição em uma sentença aprovada e louvada pela filosofia conimbricense, que é a mais autorizada e elegante que até agora apareceu no mundo: Scite, dictum est, ut speculum oculis est artis, ita oculum esse natura speculum: Quer dizer este grande reparo filosófico, que assim os espelhos são os olhos da arte. Os olhos são espelhos da natureza, porque neles se retratam as imagens de quem se vê, a quem chamamos meninas (VIEIRA, 1993, Vol. I, p. 1180).

Em uma interessante passagem (do "Sermão Da Quinta Quarta-Feira da Quaresma" de 1669), Vieira cita Lucílio comentando sobre uma história que lhe contara Sêneca: 
Refere Sêneca um caso notável, sucedido na sua família, e diz a seu discípulo Lucílio, que lhe contará uma coisa incrível, mas verdadeira. Incredibilem tibi narro rem, sed veram. Tinha uma criada chamada Harpastes, a qual, sendo fátua de seu nascimento, perdeu subitamente a vista: Haec fatua subito desiit videre. E que vos parece que fazia Harpastes cega e sem juízo? Aqui entra a coisa incrível. Nescit esse se caecam: era cega, e não o sabia. Paedagogum suum rogat ut migret: quando o que tinha cuidado dela lhe dava a mão para a guiar; lançavao de si. Ait domum tenebrosam esse: dizia que estava a casa às escuras, que abrissem as janelas; e as janelas que tinha fechadas não eram as da casa, eram as dos olhos. Pode haver cegueira mais fátua e mais digna de riso? Pois hás de saber; Lucílio, diz Sêneca, que desta maneira somos todos: cegos e fátuos. Cegos porque não vemos, e fátuos porque não conhecemos a nossa cegueira (VIEIRA, 1993, Vol. II, p. 115).

Quanto à relação dinâmica entre a visão e o entendimento, poderíamos fazer algumas considerações a partir deste excerto. $\mathrm{O}$ exemplo aqui tem objetivo quase de fábula, no sentido de propor uma ética e de desvelar certo modo de ser do homem. Contudo, pode indicar também uma relação entre visão e intelecto, onde há um desarranjo entre ambos. As instâncias em Harpastes se apresentam dissociadas não se dando conta uma da outra. A cegueira orgânica não é percebida pela precária racionalidade da criada de Sêneca. Vieira, partindo de Sêneca, joga engenhosamente com as ideias de acuidade visual e acuidade racional. Uma clara percepção do mundo pode proporcionar um claro entendimento deste, e o mesmo para a recíproca.

Apesar de se possuir a potência da visão, esta se atualiza conforme a dinâmica interna a possibilitar. A vontade, os afetos e mesmo o pensamento em geral influenciam na apreensão das espécies fornecidas pelos órgãos do sentido. No trecho seguinte, Vieira desenvolve o argumento sobre o motivo pelo qual os discípulos não reconheceram Cristo encontrando-o depois de ressuscitado:

Alguns quiseram dizer que a razão deste engano ou desta cegueira, foi porque o Senhor mudara as feições do rosto, e ainda a voz ou tom da fala. Mas esta exposição (como bem nota Santo Agostinho) é contra propriedade do Texto, o qual diz expressamente, que o engano não foi da parte do objeto, senão da potência; não da parte do visto, senão da vista: Oculi illorum tene bantur, ne eum agnoscerent [...] porque tinham os olhos presos [...] Não estavam presos por parte da vista: estavam presos pela parte da advertência. Iam os discípulos divertidos na sua prática, e muito mais divertidos na sua tristeza [...] E esta diversão do pensamento, era que lhes prendia a advertência dos olhos. Como tinham livre a vista, viam a Cristo: como tinham presa a advertência, não conheciam que era Ele [...] Vede a força que tem o pensamento para a diversão da vista! Os olhos estavam no caminho com Cristo vivo, o pensamento estava na sepultura com Cristo morto: e pode tanto a força do pensamento, que o mesmo Cristo ausente, em 
que cuidavam, os divertia do mesmo Cristo presente, que estavam vendo. Tanto vai de ver com a atenção e advertência, ou ver com desatenção e divertimento (VIEIRA, 1993, Vol. II, p. 104,105).

De acordo com o pregador, o divertimento da vista, ou seja, a falta de atenção para com o objeto, é que produziria uma ineficácia do sentido da visão. Porém, neste caso do Evangelho, Vieira justifica a percepção incorreta dos discípulos com uma intervenção divina, sendo a incorreção geral da percepção humana esta sim vinculada à desatenção com seu objeto: "Eles não viam o que viam, porque lhes confundiram Deus as espécies. Nós, sem confusão nem variedade das espécies, não vemos o que vemos, só por desatenção e divertimento da vista" (VIEIRA, 1993, Vol. II, p. 105).

Tal potência pode ser afetada e sua atualização distorcida, provocando desatenção, produzindo uma postura frente a realidade marcada por enganos:

\begin{abstract}
Porque assim como há muitos que olham para cegar, que são os que olham sem tento, assim há muitos que vêem sem olhar, porque vêem sem atenção. Não basta ver para ver; é necessário olhar para o que se vê. Não vemos as coisas que vemos, porque não olhamos para elas. Vemo-las sem advertência e sem atenção, e a mesma desatenção é a cegueira da vista. Divertem-na a atenção os pensamentos, suspendemnos a atenção os cuidados, prendem-nos a atenção os desejos, roubamnos a atenção os afetos, e por isto, vendo a vaidade do mundo, imos após ela, como se fora muito sólida; vendo o engano da esperança, confiamos nela, como se fora muito certa; vendo a fragilidade da vida, fundamos sobre ela castelos, como se fora muito firme; vendo a inconstância da fortuna, seguimos suas promessas, como se foram muito seguras; vendo a mentira de todas as coisas humanas, cremos nelas, como se foram muito verdadeiras (VIEIRA, 1993, Vol. II, p. 105,106).
\end{abstract}

Em uma potente leitura exegética da realidade (que em Vieira vem mesclada com a transcendência), o jesuíta recorre à "filosofia da alma" para demonstrar como a inveja (uma paixão) pode intervir e subvertes as funções anímicas causando engano. Em um discurso apologético, entra em defesa de Santo Antônio contra a inveja dos homens em seu "Sermão de Santo António":

Notai este terrível e diabólico círculo, que a inveja faz com causalidade recíproca entre a potência de ver, e o objecto visto. A vista, ou se faz por espécies, que o objecto manda à potência, ou por raios, que a potência manda ao objecto: e estas duas opiniões contrárias dos filósofos, conciliou e ajuntou a inveja para fazer guerra ao bem, que não pode ver. Pelas espécies que saem do objecto, faz que sendo o objeto bom, os olhos sejam maus; e pelos raios que saem dos olhos, faz que sendo os olhos maus, o objeto não seja bom. De maneira que a bondade do objeto faz a maldade da potência, e a 
maldade da potência desfaz a vontade do objecto. Porque eu sou bom, os teus olhos são maus: e porque os teus olhos são maus, eu não heide ser bom. Vede se metidas entre tal casta de olhos, podiam ser as obras de Santo António boas: Ut videant opera vestra bona" (VIEIRA, 1993, Vol. III, p. 115).

Porém, essa modulação da vista e sua sujeição a afetos e pensamentos de que fala Vieira, muito possivelmente não esta ligada apenas ao sentido externo da visão, situado na alma, mas à potência imaginativa. A forte influência dos afetos - paixões e apetites sensitivos- vinculados à percepção das espécies já é do campo dos sentidos internos, ou seja, das potências da alma sensitiva, especificamente da imaginação. É a imaginação que solicita a adesão do apetite e ao mesmo tempo pode atuar segundo os ditames deste. Dos apetites geram-se as paixões. Logo, o erro da vista de que trata Vieira, pode ser entendido como a distorção da percepção feita pela imaginação, dada a influência das paixões. É o que notamos no fragmento a seguir:

A paixão é a que erra, a paixão é a que os engana, a paixão é a que lhes perturba e troca as espécies, para que vejam umas coisas por outras. E esta é a verdadeira razão, ou sem-razão, de uma tão notável cegueira. Os olhos vêem pelo coração, e assim como quem vê por vidros de diversas cores todas as coisas lhe parecem daquela cor, assim as vistas se tingem dos mesmos humores de que estão bem ou mal afetos os corações (VIEIRA, 1993, Vol. III, p. 111).

Assim, a paixão é capaz de modular a imaginação. Esta última na medida em que cede aos afetos pode arrebatar a vontade e o entendimento de uma maneira enganosa. A imaginação pode distorcer os fatos e mobilizar o sujeito a uma determinada atuação. O que Vieira parece colocar é que uma das características da imaginação é mobilizar vontade e entendimento ao se formular certo juízo. No seguinte excerto, Vieira parece indicar tal propriedade da imaginação, porém manifestada de forma enganosa. Age-se segundo o que se imagina e não em consequência do que acontece de fato:

Os apóstolos, Assuero, os moabitas, todos estavam com os olhos abertos, todos viram o que viam, e todos julgaram uma coisa por outra. Pois, se os apóstolos viam a Cristo, como julgavam que era fantasma? Se Assuero viu a Amã em ato de pedir misericórdia, como julgou que lhe fazia adultério? Se os moabitas viam a água da ribeira, como julgaram que era sangue? Porque assim confundem e trocam as espécies da vista os olhos perturbados com alguma paixão. Os apóstolos estavam perturbados com a paixão do temor; Assuero com a paixão da ira; os moabitas com a paixão do ódio e da vingança; e como os moabitas desejavam verter o sangue dos dois exércitos inimigos, a água lhes parecia sangue; como Assuero queria tirar a vida a Amã, a contrição lhe parecia pecado; como os apóstolos estavam medrosos com o perigo, o remédio, e o mesmo Cristo lhes parecia 
fantasma. Fiai-vos lá de olhos que vêem com paixão. As paixões do coração humano, como as divide e enumera Aristóteles, são onze, mas todas elas se reduzem a duas capitais: amor e ódio. E estes dois afetos cegos são os dois pólos em que se revolve o mundo, por isso tão mal governado (VIEIRA, 1993, Vol. III, p. 112,113).

Deste modo, o ver seria o primeiro passo de um encadeamento que se inicia na percepção dos dados sensíveis (apreensão das espécies), passando pelas demais componentes da esfera sensitiva - com destaque para a imaginação e sua relação com os afetos e paixões - chegando à deliberação do sujeito e sua ação. Escreve Vieira no Sermão das Lágrimas de S. Pedro de 1669:

Com os olhos o que há-de pecar, entra pela vista, da vista passa à imaginação, e da imaginação ao consentimento: logo (para que não chegue ao consentimento) nos olhos, onde está o primeiro perigo, se há-de pôr a cautela, os olhos a resistência, nos olhos o remédio. (...) A primeira ancila e a primeira tentadora é a vista; a segunda ancila e a segunda tentadora é a imaginação: e o teceiro tentador é o consentimento, em que se consuma o pecado. E assim como nas negações de Pedro a primeira tentadora foi a ancila ostiária, a porteira; assim nas nossas negações a primeira tentadora é a vista, que é a porteira, e a que tem nos olhos as chaves das outras potências" (VIEIRA, 1993, Vol. II, p. 586-587).

Um dos possíveis remédios ao erro da vista é o escrúpulo da consciência. Conforme a etimologia escrúpulo quer dizer pedrinha, sendo a pedrinha no sapato que tenciona o caminhar (a ação, a obra), mas não o impede. Manifestado mais especificamente através da virtude da prudência. Vieira extrai como exemplo do Evangelho a prudência de José, que mesmo diante da evidente gravidez de Maria, não a expõe, pretendendo abandona-la em segredo, refreando assim suas paixões e sacrificando sua cega vista:

O ciúme guiava a José, o amor guiava o ciúme; e sendo cego o ciúme, e cego o amor, não foram bastantes dous afectos cegos, e tão cegos, para que a prudência de $\mathrm{S}$. José se precipitasse. Disse afectos cegos e tão cegos; porque os ciúmes de S. José eram fundados nas evidências do que via, e não há mais perigosas cegueiras, que as que têm da sua parte os olhos (VIEIRA, 1993, Vol. II, p. 1326).

Da mesma maneira, o que entra pelos ouvidos pode igualmente ser conduzido pela imaginação e tornar-se, como diz o pregador, uma "fábula". No caso da pregação, quando esta não tem fundamento de verdade perde sua eficácia:

"Quantas vezes ouço dizer que são palavras vossas o que são imaginações minhas, que me não quero excluir deste número! Que muito logo, que as nossas imaginações e as nossas vaidades e as nossas fábulas não tenham a eficácia de palavra de Deus" (VIEIRA, 1993, Vol. I, p. 100, 101). 
Apregoa Vieira em uma passagem do sermão da Sexagésima a falta de decoro de alguns pregadores e suas argumentações fundadas apenas nas próprias imaginações e pautadas em uma oratória extravagante, gerando pregações quase burlescas. Ausenta-se a verdade, expõe-se a fabulação:

...fecharão os ouvidos à verdade e abri-los-ão às fábulas. Fábula tem duas significações: quer dizer fingimento, e quer dizer comédia, e tudo são muitas pregações deste tempo. São fingimento, porque são subtilezas e pensamentos aéreos, sem fundamento de verdade: são comédia, porque os ouvintes vêm à pregação como à comédia, e há pregadores que vêm ao púlpito como comediantes (VIEIRA, 1993, Vol. I, p. 101).

Como na visão, o sentido da audição pode tanto oferecer os subsídios para a imaginação atuar, como ser plasmado por ela. No "Sermão Da Quinta Dominga da Quaresma" de 1654,Vieira constrói um exemplo a partir de uma passagem bíblica do Antigo Testamento, são apresentados Moises e Josué diante de um mesmo alarido da multidão. Cada um deles interpreta o que ouve segundo sua disposição. Tal disposição é dada segundo o inaciano pela inclinação e pelo coração de cada um:

Se as vozes eram as mesmas, como a um parecem música e a outro parecem trombetas? A razão é clara. Moisés era religioso, Josué era soldado: ao religioso, parecem-lhe as vozes do coro; ao soldado, de guerra. Cada um ouve conforme o seu coração e a sua inclinação. Deus nos livre de um coração mal inclinado. Se ouvir um Te Deum laudamus há de dizer que ouviu uma carta de excomunhão. Os que ouvem são os ouvidos, mas os que ouvem bem ou mal são os corações. Tudo o que entra pelo ouvido faz eco no coração, e conforme está disposto o coração, assim se formam os ecos (VIEIRA, 1993, Vol. II, p. 169, 170).

O coração - sede das paixões na filosofia Aristotélica e do juízo na tradição judaico-cristã - concorre para a modulação do que é captado pelos sentidos e julgado pelo intelecto. Uma predisposição de afetos poderia condicionar uma dada compreensão da realidade. Poderíamos pensar novamente na matriz aristotélico-tomista: sendo a alma forma substancial, tal noção filosófica pressupõe o princípio de individuação. Em linhas gerais, o jesuíta nos remete a possibilidades de almas diferentes se constituírem de formas particulares, continuando todas elas ainda como almas. As relações entre potências e sentidos são plurais, sendo organizadas segundo a alma de cada um, obedecendo às circunstâncias e ao alvedrio próprio. A fôrma interna (o coração), como diria o pregador, poderia ser de um santo ou um demônio. Segue como ilustração, uma engenhosa metáfora de Vieira contida no "Sermão Da Quinta Dominga da Quaresma" de 1654: 
Quer um fundidor formar uma imagem. Suponhamos que é de S. Bartolomeu com o seu diabo aos pés. Que faz para isto? Faz duas formas de barro, uma do santo e outra do diabo, e deixa aberto um ouvido em cada uma. Depois disto derrete o seu metal em um forno, e, tanto que está derretido e preparado, abre a boca ao forno, corre o metal, entra por seus canais no ouvido de cada forma, e em uma sai uma imagem de S. Bartolomeu muito formosa, noutra uma figura do diabo, tão feia como ele. Pois, valha-me Deus, que diferença é esta? O metal era o mesmo, a boca por onde saiu a mesma, e, entrando por um ouvido faz um santo, entrando por outro ouvido faz um diabo? Sim, que não está a coisa nos ouvidos, senão nas formas que estão lá dentro. Onde estava a forma do diabo, saiu um diabo; onde estava a forma do santo, saiu um santo. Senhores meus, todos os nossos ouvidos vão a dar lá dentro em uma forma, que é o coração. Se o coração é forma do santo, tudo o que entra pelo ouvido é santo; se é forma do diabo, tudo o que entra pelo ouvido é diabólico (VIEIRA, 1993, Vol. II, p. 170).

Quando o pregador abre a boca e deixa correr o metal de seu discurso ele considera que é o coração da pessoa quem define a imagem final. É a inclinação ordenada (santo) ou desordenada (diabólico) dos afetos do coração que definirá a leitura da realidade e o posicionamento humano frente a ela. Portanto, há um movimento próprio do ouvinte para a adesão do discurso, e há um reconhecimento prévio já na composição do discurso, da constituição humana do ouvinte. Fundem-se livre alvedrio, Graça e discurso.

\subsection{Imaginação e Memória: dinamismo psiquico e persuasão}

Faremos agora uma tentativa de evidenciar o processo de metanóia proposto em alguns sermões em uma perspectiva da dinâmica da alma.

A persuasão e consequente metanóia acontecem, em última instância, na alma racional, mas haveria um caminho a ser percorrido antes de se adentrar ao espirito buscando seu assentir (consentir por convicção). Em outras palavras, a dimensão préracional intervém no espírito.

Já damos aqui lugar à imaginação, componente imprescindível do processo de conversão. A razão, através da imaginação, pode colher o conhecimento, bem como esta mesma imaginação orientada pelo entendimento, pode mobilizar a esfera pré-racional. O orador vai descrevendo a dinâmica interna dos processos da alma através da retórica, em um processo metalinguístico, articulando imaginação a entendimento e vontade. Ao mesmo tempo, realiza através da palavra essa mesma dinâmica em seus ouvintes. $O$ 
exemplo é do "Sermão da Quarta Dominga do Advento", onde Vieira conta que o rei Nabucodonossor foi transformado em bruto como penitência. Tal transformação poderia ter se dado de fato, ou apenas na imaginação do rei:

Se foi transformação imaginária, voltou Nabucodonossor os olhos para dentro de si mesmo, e viu tão vivamente o que era, que desde aquele ponto se não teve mais por homem, senão por bruto, e como tal se tratava. Se foi transformação verdadeira, converter Deus em bruto Nabucodonossor, não foi outra cousa que virá-lo de dentro para fora, para que mostrasse por fora na figura, o que era por dentro na vida (VIEIRA, 1993, Vol. II, p. 317).

Assim, Vieira vai criando a figura do "novo monstro", o bruto racional, homem que possui em si a razão, mas por cegueira - causada pelo amor-próprio, representado pelos afetos e apetites não ordenados -, está destituído desta, enganado:

Andou pascendo aquele bruto racional o primeiro dia de sua transformação entre os animais; lá pela tarde teve sede; foi-se chegando sobre quatro pés à margem de um rio, e quando reconheceu no espelho das águas a deformidade horrenda de sua figura valha-me Deus, que assombrado ficaria de si mesmo! Provaria primeiro fugir de si; mas como se visse atado tão fortemente àquele tronco bruto, remeteria a precipitar-se na corrente; e se Deus o não tivesse mão, porque o queria trazer por aqueles campos de Babilônia para exemplo eterno de soberbos, ali ficaria sepultado, primeiro em sua confusão, e depois na profundidade do rio. Que rio é este, senão o rio Jordão: Fluvis judici: rio do juízo? E que é este Nabucodonossor assim transformado, senão o pecador, bruto sem razão, sem uso dela, que anda pascendo nos campos deste mundo entre os outros animais, mais animal que eles? (VIEIRA, 1993, Vol. II, p. 318).

Aparentemente, referindo-se ao mito grego de Narciso, Vieira propõe a imagem deste "bruto racional" olhando para o espelho d'água, no rio do juízo. Porém, contrariamente ao mito, a imagem é aversiva. Fala das "distorções" e "deformidades" do interior da alma humana da qual os homens não se percebem, nem se reconhecem, tendo uma imagem de si mesmos não correspondentes ao que realmente são. Descreve as feições da alma, criando a imagem de um rosto, onde as partes deste seriam os componentes da interioridade que reflete o homem, e as mãos seriam as obras:

Chega enfim o pecador a ver-se nas águas deste rio, espelhos naturais, e sem adulação; vê de repente o que nunca tinha visto: vê-se a si mesmo. Oh que assombro! É possível que este sou eu? Tal fealdade, tal horror, tal bruteza, tais deformidades há em mim? Sim; e muito maiores. Esse sois, e não o que vós cuidáveis. Vede se diz esse retrato com o que vós tinhéis formado de vós mesmo no vosso pensamento; vede bem, e considerai muito devagar nesse espelho, o rosto e as feições interiores da alma; vede bem esses olhos, que são as vossas intenções; esses cabelos, que são vossos pensamentos; essa boca, que são as vossas palavras; essas mãos, que são as vossas acções e as vossas obras; vede bem se diz essa imagem com a que tendes na vossa 
idéia; vede se parece o que vedes com o que imagináveis; vede se vos conheceis; vede se sois esse, ou outro: Tu quis es? (VIEIRA, 1993, Vol. II, p. 318,319).

Assim, Vieira parece retomar novamente sua formação escolástica. Segundo os Conimbricences, a vontade pressupõe o conhecimento, mas também depende do apetite sensitivo o qual, por sua vez, segue a fantasia (ZANLONGHI, 2003). É a potência imaginativa (fantasia) que desperta no bruto racional, o pecador, o apetite irascível, ou seja, indica o que seria repulsivo e propenso a fuga. Desta forma, a imaginação orientada pela razão propicia uma nova possibilidade de disposição da vontade. Porém, em última instância será o alvedrio que definirá o posicionamento da vontade e a consequente metanóia, escreve Vieira no "Sermão da Terceira Dominga Post Epiphaniam":

"Maior a tempestade, porque a daquele dia levantaram-na os mares e os ventos, que sempre obedeceram a seu Criador: a destes dias levantava-a o apetite, a paixão e o livre alvedrio humano, cuja rebeldia só pode resistir a Deus, e dizer-lhe na cara: Não quero" (VIEIRA, 1993, Vol. I, p. 556).

Neste sentido, a imaginação propiciaria ferramentas ao entendimento para que a vontade possa agir. Justapondo psicologia filosófica, teologia e ética, Antônio Vieira articula em seu discurso entendimento e vontade. A vontade pressupõe entendimento, sendo que o entendimento goza de autonomia:

"Quando o Padre ab aeterno gera o Filho, gera-O por puro
entendimento, sem intervenção da vontade; quando o Padre e o Filho
produzem o Espírito Santo, produzem-No por acto da vontade, mas já
com suposição do entendimento. Pois por isso o dar se atribui à
terceira pessoa, e o julgar à segunda; porque o dar a de ser da vontade,
mas com suposição de entendimento; o julgar há-de ser só do
entendimento sem intervenção nenhuma da vontade" (VIEIRA, 1993,
Vol. I, p. 231)

A passagem pertence ao "Sermão da Segunda Dominga do Advento". O argumento a ser provado é de que os homens julgariam erroneamente segundo a vontade e não conforme o entendimento. Aqui, possivelmente por uma inspiração tomista, filosofia e teologia são complementares. Por indução, o pregador parte da imagem da Trindade (a qual seria considerado inconteste, devido sua natureza doutrinal) e chega ao plano moral. O que subsidiaria o engenhoso traslado entre o particular (mesmo sendo do campo do transcendente) ao geral (ética) seria a psicológica filosofia aristotélico-tomista. Como já dito, o ato de vontade supõe a priori o conhecimento (entendimento). Não obstante, o ato de entender goza de certa autonomia em relação a 
outras instâncias, no sentido de ser um ato em si da alma. Porém, para o inteligir acontecer concorrem outras instância anímicas.

A vontade por sua vez, apesar de poder ceder aos apelos da esfera pré-racional, pode também agir sobre os apetites, para orientá-los e discipliná-los, indicamos "o Sermão Da Primeira Sexta-Feira da Quaresma” de 1644:

Temos hoje em controvérsia os dois mais poderosos afetos, e os dois mais perigosos da vontade humana. Tão poderosos que, se a vontade os vence, é senhora; tão perigosos que, se eles vencem a vontade, é escrava. E que dois afetos são estes? Amor e ódio (VIEIRA, 1993, Vol. I, p. 689).

Os caminhos para realizar um "governo político da alma" passam através dos sentidos internos, os quais são o lugar interior que permite a passagem para o intelecto e vontade. Neste processo, o papel da potência cogitativa é fundamental, sendo que a persuasão passa assim por ela. Cipriano Soares (1580), no compêndio de retórica ${ }^{20}$ indica o processo que une a vontade, a razão, a potência cogitativa e os apetites, evidenciando assim as raízes psicológicas da persuasão e da retórica: atuando sobre os sentidos interno, a palavra eloquente suscita o interesse da imaginação. Ao tornar bela a própria verdade, através do aprazível, estimula o apetite e solicita a adesão (Soares, 1580).

Portanto, a palavra pode mover a dinâmica interna politice regendo, non cogendo (Zanlonghi, 2003). Os apetites e paixões são tratados como cidadãos da alma e não tanto como servos, sendo submetidos "politicamente" e não de maneira "despótica" (Zanlonghi, 2003). O próprio Vieira assinala em seu "Sermão de Santo Antônio" de 1642: "Razão é que por todas as vias se acuda à conservação; mas como somos compostos de carne e sangue, obre de tal maneira o racional, que tenha sempre respeito ao sensitivo" (VIEIRA, 1993, Vol. III, p. 157).

\footnotetext{
${ }^{20}$ Para a formação nos colégios da Companhia de Jesus foram muito importantes os manuais de retórica, com destaque para o compêndio de Soares, "O modelo de pregação jesuítica é rigorosamente fiel aos métodos da tradição católica e aos decretos tridentinos, consensado num compêndio utilizado para a formação retórica nos colégios da Companhia, a partir do fim do século XVI, elaborado pelo jesuíta português Cipriano Soares, o De arte rhetorica libri tres (Coimbra, 1560). Inácio, nutrido por uma sólida cultura clássica, proclama diretrizes que previam a leitura direta dos grandes textos da retórica clássica, alinhavada segundo os cânones da cultura humanista. Por isso, esse primieiro manual de retórica oficialmente adotado nas escolas da Comapnhia é uma espécie de resumo de passos derivados de Aristóteles, Cícero e Quintiliano. O pequeno compêndio, devido a seu caráter sintético, teve centenas de reedições e alcançou uma ampla difusão na Europa (consta nos currículos de colégios jesuítas italianos, portugueses, espanhóis, flamengos e alemães)" (MASSIMI, 2005, p. 93)
} 
Assim, a retórica através do governo das paixões, ordena a vontade e estimula a adesão aos preceitos propostos por meio de desengano conforme escreve o inaciano em seu "Sermão Da Primeira Sexta-Feira da Quaresma" de 1644:

Engana-nos o mal com aparências de bem, e leva-nos o amor; engananos o bem com aparências de mal, e mete-nos no coração o ódio. E que fará a triste vontade enganada assim, e cativa? O desengano destes dois erros é o que eu determino pregar hoje, e ensinar, não às más, senão às boas vontades, como hão de saber amar, e como hão de saber aborrecer. É matéria em que, depois de disputada a controvérsia, vos hei de descobrir um admirável segredo (VIEIRA, 1993, Vol. I, p. 690).

\subsection{Imaginação e Memória: Conhecimento e Juízo de Si}

Não apenas o conhecimento da realidade passa pela faculdade imaginativa, mas também o conhecimento de si. Vieira, pregando em Roma para a corte da rainha Cristina da Suécia sua sequência de sermões intitulada As cinco pedras da funda de David (VIEIRA, 1993, Vol. V), arguia no primeiro sermão sobre a primeira pedra que seria o conhecimento de si (o tema é recorrente em outros sermões, principalmente os dos tempos litúrgicos da quaresma e advento). Segundo o pregador, o primeiro motor de nossas ações é o conhecimento de nós mesmos, melhor dizendo, a maneira como nos percebemos, nossa autoimagem. Assim, as ações se dariam em consequência dos pensamentos, mas não quaisquer pensamentos. Falando das obras afirma, “[...] eu digo que são filhas do pensamento e da ideia, com que cada um se concebe, e conhece a si mesmo" (VIEIRA, 1993, Vol. V, p. 610). A maneira como cada um se concebe na imaginação, seria a maneira pela qual cada um age:

Aqueles animais do carro de Ezequiel, cada um tinha quatro cabeças em um só corpo [...] Que cada qual daquelas cabeças, ainda que no mesmo corpo, produzem efeitos diferentes; e que todas saiam e se distingam com acções propriamente suas, e proporcionadas à fantasia de cada uma [...] O coração, os pés as mãos, as asas, tudo vem da cabeça, que é o molde da própria fantasia. Se esta for de homem, as acções serão racionais, se de águia, altivas; se de leão, generosas; se de bois, vis (VIEIRA, 1993, Vol. V, p. 611).

Neste sermão, o jesuíta traz como já aludido, as duas naturezas do homem, a sensitiva, corpórea, sensual e a anímica propriamente espiritual, sendo estas as duas "peças" as quais compõem o homem. Deste modo, torna-se necessário conhecê-las, darse conta delas e elaborar juízo sobre qual representa mais o homem. As ações e posicionamentos humanos estão fortemente vinculados ao conhecimento de si mesmo, tanto de forma negativa quanto positiva. Afirma Vieira no "Discurso Primeiro": 
Sendo, pois, o conhecimento de si mesmo, e o conceito que cada um faz de si uma força tão poderosa sobre as próprias acções; e sendo também o homem um composto pouco menos quimérico, formado de duas partes tão distantes como lodo e divindade, ou quando menos um sopro dela; eu não sei na verdade como possa declarar ou definir ao homem o útil conhecimento de si mesmo. Se lhe digo que se conheça pela parte inferior e terrena, temo que um conceito tão baixo produza acção vis como em Adão; se pela parte superior e tão alta, temo que a mesma alteza de seu conhecimento degenere em inchação e soberba, como em Lúcifer. Aquele caiu porque não conheceu sua nobreza: Homo, cum in honore esset, nom intellexit. Este caiu, porque a conheceu: Perdidisti sapientiam tuam in decore tuo. E entre um e outro perigo, não sei qual dos dous precipícios seja maior" (VIEIRA, 1993, Vol. V, p. 612)

Os cinco sermões foram pregados em momentos diferentes por ocasião da quaresma daquele ano. Peças musicais e outros entretenimentos acompanhavam os sermões para deleite da corte promovendo um espetáculo. Vieira não priva a corte de seu deleite e maravilhamento, mas introduz ao mesmo tempo seu desengano, dando o lugar próprio do sermão. Acomodando seu sermão à situação e ao auditório, o jesuíta indica os dois aspectos da realidade que se fazem presentes naquele momento, ou seja, os regalos do sensível, presentes no evento, e a espiritualidade contida no sermão. Na argumentação, o inaciano procura demonstrar a dupla natureza do homemsensível/corpórea e espiritual - indicando a espiritualidade como lugar mais próprio para o homem se conhecer:

Qual será logo no homem o limpo conhecimento de si mesmo? Digo que é conhecer e persuadir-se cada um, que ele é a sua alma. O pó, o lodo, o corpo, não é eu; eu sou a minha alma: este é o verdadeiro, o limpo e o heroico conhecimento de si mesmo; heroico porque se conhece o homem pela parte mais sublime; o limpo, porque se separa totalmente de tudo o que é terra; o verdadeiro, porque ainda que o homem verdadeiramente é composto de corpo e alma, que se conhece pela parte do corpo, ignora-se, e só que se conhece pela parte da alma se conhece. Não sei se saberei declarar-me. Assim como um espelho se compões de aço e cristal, assim o homem se compõe de corpo e alma: e que sucederia a quem se visse, ou por um ou por outro lado? Quem olha para o espelho pela parte do aço, vê aço, mas não se vê a si: quem olha pela parte do cristal vê ao cristal, e no cristal vê-se a si mesmo. Assim neste espelho da natureza humana, que o olha pela parte térrea e opaca, que é o corpo, vê o corpo, mas não vê o homem: quem o olha pela parte celeste e luminosa, que é a alma, vê a alma, e na alma vê e conhece ao homem; porque vê e conhece o que ele é, e o que o distingue e enobrece sobre todas as criaturas da Terra (VIEIRA, 1993, Vol. V p. 614).

Deste modo, como o próprio Vieira adverte não se desconsidera, ou desvalorizase o corpo, sendo este constitutivo do homem, mas destaca-se a alma. O engano é manter-se nas impressões e percepções que podem dar-se pela materialidade, devendo- 
se buscar a natureza espiritual que a materialidade vela e ao mesmo tempo sinaliza: "Assim é no homem o conhecimento de si mesmo: se para no corpo, ignora-se; se reflecte sobre a alma, conhece-a; saia logo do corpo, e sacuda-se do pó, se quer conhecer-se: Si ignoras te, egredere" (VIEIRA, 1993, Vol. V, p. 614).

Ainda pensando nesta perspectiva, em sermões do tempo do Advento, o pregador refle sobre a alma e seu conhecimento. Vieira compõe a dinâmica dos afetos de modo a relacioná-los com o entendimento. O homem envolvido em uma dinâmica afetiva pode ter em seu interior a fonte de todos os enganos, mas também da salvação. São as relações travadas entre conhecimento e afetos que definem o modo pelo qual o ser humano perceberá o mundo e conceberá a si mesmo, e como tal atuará na realidade.

Vieira parece referir-se a duas sortes de engano: o engano sobre mundo, e o engano que se refere ao juízo de si. No engano sobre o mundo, o homem se relaciona com a realidade e com o outro distorcendo o real sentido das coisas, deixando-se levar pela imaginação, atribuindo valor as coisas conforme os apetites e enganando a vontade. No engano do juízo de si, o homem não se percebendo como é, deturpa sua autoimagem através do amor-próprio, esquecendo-se de sua própria condição humana sujeita a todas as vicissitudes, sendo frágil e mortal. Desta forma, cria-se uma distância, segundo o pregador, entre o que os homens realmente são e o que dizem a respeito de si mesmos: "porque os homens quando testemunham de si mesmos, uma cousa é o que são, e outra cousa é o que dizem” (VIEIRA, 1993, Vol. I, p. 256). Vieira desenvolve explicitamente o argumento no "Sermão da Terceira Dominga do Advento":

Nesta matéria de vos quem sois, todo o homem mente duas vezes; uma vez mente-se a si, e outra vez mente-nos a nós: mente-se a si, porque sempre cuida mais do que é; e mente-nos a nós, porque sempre diz mais do que cuida. Bem distinguiram logo os embaixadores o Tu quis es, do Quid dicis de te ipso; e quando iam perguntar ao Baptista o que era, perguntaram o que dizia; porque ninguém há tão recto juiz de si mesmo, que ou diga o que é, ou seja o que diz (VIEIRA, 1993, Vol. I, p. 256).

Levanta-se aqui um ponto interessante: o argumento de que o homem na matéria de "vós quem sois", das duas vezes que mente, uma mente a si mesmo. Vieira fala que neste caso, o conhecimento de si seria "mentiroso": aqui aparece o engano, não sobre as coisas do mundo, mas sobre o juízo de si. A vontade é enganada não na percepção do mundo, mas na percepção interna, na consciência de si. A imaginação atua produzindo uma autoimagem equivocada. 
Para desenganar a "consciência de si”, Vieira dá como solução a penitência como um elemento pedagógico. O penitente sendo aquele que se volta para Deus, em uma primeira atitude assumiria para si seus pecados e segundo o jesuíta, "ninguém melhor do que nossos pecados, para dizer quem somos" (VIEIRA, 1993, Vol. I, p. 171). Aqui o fator preponderante é o uso da memória, o que a penitência busca é o fazer memória de Deus por um lado e a lembrança dos pecados por outro.

Eu sou o que me prezo de entendido; e cometi tantas vezes uma ignorância tão feia, como antepor a criatura ao Criador, a suma miséria ao sumo e infinito bem! Não sou entendido, sou néscio. Eu sou o que me prezo de sisudo e cometi tantas vezes uma loucura tão emendada, como arriscar por um apetite leve, por um instante de gosto, uma eternidade de Glória, ou de Inferno! Não sou sisudo, sou louco. Desta maneira emenda o juízo da penitência os erros e as cegueiras do nosso. Em lugar de sisudo, põe louco; em lugar de discreto, néscio; em lugar de valeroso, covarde; em lugar de honrado, vil; e aquilo que cuidávamos, isto o que somos. Ninguém nos diz melhor o que somos, que os nossos pecados (VIEIRA, 1993, Vol. I, p. 322)

Porém, em última instância, são as obras que definem quem é o homem e para onde este se inclina:

Uma árvore antes de se cortar não se conhece muito fácil e muito naturalmente para que parte há-de cair? Pois assim o pode conhecer cada um de si, dentro em si mesmo. (...) Se quereis saber para onde há-de cair a árvore, quando for cortada, olhai para ela, e vede para onde inclina o com o peso dos ramos. (...) Olhe agora cada um, e olhe bem para a sua alma, e para as suas obras, que estas são os ramos da árvore (VIEIRA, 1993, Vol. I, p. 171).

Assim, é necessário o conhecimento de si, para então passar à ação de crescer, desenvolver-se como pessoa: "Não digo que não trate cada um de crescer, mas conheça cada um o que é: Tu quis es? E depois cresça conforme a sua espécie: Secundum speciem suam" (VIEIRA, 1993, Vol. I, p. 266).

O tema do juízo de si é expresso de maneira ainda mais explicita por Vieira no tendo um significado especial para o autor e submetendo a este a ordem de três sermões pregados anteriormente.

Vieira se propõe, no "Sermão da Quarta Dominga do Advento", a persuadir o seu auditório através da mobilização dos afetos e o diz de maneira clara quando declara querer pregar aos corações. Fica também anunciada a importância maior do último sermão que finaliza o tempo litúrgico do Advento, pois é neste que se colhem os frutos, ou seja, converte-se o ouvinte. Vieira parece aqui indicar que, pela ordem dos sermões, 
solicita-se primeiro o entendimento, mas é pelo coração, ou seja, o universo pertinente às paixões, afetos e consciência, que se converte:

Tenho proposto (católico e nobilíssimo auditório) a matéria deste último sermão. E se nos passados mereci alguma cousa a vossos entendimentos (quod sentio quam sit exiguum) quisera que mo pagassem hoje vossos corações. Aos corações determino pregar hoje, e não aos entendimentos. Cristo, soberano exemplar dos que pregam sua palavra, comparou os pregadores aos que lavram e semeiam: Exiit qui seminat seminare: sem est verbum Dei. O último sermão é o Agosto dos pregadores: se colhe algum fruto, neste sermão se colhe (VIEIRA, 1993, Vol. I, p. 314).

A imagem do tribunal é evocada por Vieira, onde se inicia o processo judicial, e os juízos são personificados: serão julgados o juízo de si, o juízo dos homens e o juízo de Deus. O amor-próprio, primeiro a ser julgado, impediria que fosse realizado um coerente juízo de si, adulterando na imaginação as percepções de si e do mundo:

No tribunal dos areopagitas em Atenas, costumavam entrar os réus com os rostos cobertos. Assim entra e se apresenta no tribunal da penitência, o juízo de si mesmo. Entrara com os olhos tapados, porque não há juízo mais cego. A cegueira do juízo de si, que é o amorpróprio, é muito maior que a cegueira dos olhos; a cegueira dos olhos faz que não vejamos as cousas; a cegueira do amor-próprio, faz que as vejamos diferentes do que são, que é muito maior cegueira (VIEIRA, 1993, Vol. I, p. 316).

Então, Vieira evidencia o motivo pelo qual o juízo de si erra sempre, e explica “porque nunca acabamos de nos conhecer" (VIEIRA, 1993, Vol. I. p. 316): trata-se de uma relação errada entre afeto e entendimento:

Porque olhamos para nós com os olhos de um mais cego que os cegos, com uns olhos que sempre vêem uma cousa por outra, e as pequenas lhes parecem grandes. Somos pouco maiores que as ervas, e fingimonos tão grandes como as árvores; somos a cousa mais inconstante do mundo, e cuidamos que temos raízes; se o Inverno nos tirou as folhas, imaginamos que no-las há-de tornar a dar o Verão; que sempre havemos de florescer, que havemos de durar para sempre. Isto somos, e isto cuidamos (VIEIRA, 1993, Vol.I, p. 316).

"E o que faz a penitência para emendar este juízo tão sem juízo?” (VIEIRA, 1993, Vol. I, p. 316), pergunta Vieira. Ele mesmo responde: "Duas cousas. Tira-lhe o véu dos olhos, e mete-lhe um espelho na mão" (VIEIRA, 1993, Vol.I, p. 316). A penitência mostraria assim o homem a si mesmo, "Pôr-vos-ei a vós diante de vós" (VIEIRA, 1993, Vol.I, p. 317), o que segundo o autor, "emendaria” este juízo já que não é claro e fácil ao homem conhecer-se: "Nenhuma cousa trazemos os homens mais esquecida e desconhecida, nenhuma trazemos mais detrás de nós, que a nós mesmos" (VIEIRA, 1993, Vol.I, p. 317). 
Assim, o homem aparece como juiz de si próprio, evocando em sua memória e experiência a maneira como vem conduzindo sua vida, podendo prognosticar seu futuro de acordo com sua conduta até então. Pode ele também alterar seu futuro se este não lhe aprouver, através da vontade emendando seus hábitos.

\subsection{Imaginação e Memória: $O$ sentido do tempo e a existência da pessoa}

Viera procura tratar a questão do tempo em suas várias dimensões - de vida/existência, tempo cronológico, momento epocal/contemporaneidade, sendo que o Advento compila em si esta possibilidade: a priori é o fim dos tempos e o começo de um novo tempo; é herança do passado, tradição fruto da história da Igreja, mas representa também o futuro e a realização das promessas da mensagem cristã. Vieira parece se inspirar na concepção do tempo de Agostinho, segundo a qual o tempo não existe para Deus, de modo que é possível juízo pessoal e final serem idênticos, vindo o próprio Cristo para julgá-los. Este tempo influenciado pela visão agostiniana, torna-se tempo "psicológico", "subjetivo": é um tempo ligado à percepção do sujeito. Esta perspectiva parece trazer dois desdobramentos no conteúdo dos sermões, sendo o primeiro a denúncia do engano do homem, que não contemplando sua finitude, vive seu tempo na ilusão de gozar de um estado de permanência no mundo. Tal ilusão é propiciada pela imaginação, que em sua capacidade de fabulação distorce a percepção do homem sobre a realidade. Este descuido dos homens em relação ao tempo, no nosso entendimento, é o grande engano que Vieira pretende desfazer. Segundo o jesuíta, os homens têm a percepção de que não passam, ou seja, não deixam de existir. Assim, os homens consideram que são permanentes como o mundo, não se dando conta de sua própria finitude, agindo como se não fossem mortais. Perde-se assim a dimensão de criatura dependente que está inserida provisoriamente no mundo. O homem põe em risco sua salvação quando se esquece da consistência efêmera das coisas do mundo e de seus deveres, afazeres e obras no mundo. Vieira apresenta a falta da memória como empecilho para se estabelecer um correto juízo das coisas, mais uma vez o entendimento mantem-se na circunstancialidade, sem poder contar com a memória para ampliá-lo.

O pregador ilustra a falsa percepção humana através da metáfora dos homens no barco, que ao vislumbrarem as margens julgam que o que passa é justamente a paisagem e não eles próprios: 
Deste tudo que está sempre passando, é o homem não só a parte principal, mas verdadeiramente o tudo do mesmo tudo. E vendo o homem com os olhos abertos e, ainda os cegos, como tudo passa, só nós vivemos como se não passáramos. Somos como os que navegando com vento e maré, e correndo velocissimamente pelo Tejo acima, se olham fixamente para a terra, parece-lhes que os montes, as torres, e a cidade é a que passa; e os que passam, são eles (VIEIRA, 1993, Vol.I, p. 194).

A metáfora do navio e da navegação (derivada de Platão e Agostinho) exemplifica poeticamente esta visão da existência: os homens todos, embarcados na mesma nau que é a vida, navegam com o mesmo vento, que é o tempo. Assim como na nau "uns governam o leme, outros mareiam as velas; uns vigiam, outros dormem; uns passeiam, outros estão sentados; uns cantam, outros jogam" (VIEIRA, 1993, Vol.I, p. 195), mas todos igualmente sem distinção de condição e de função caminham ao mesmo porto; assim toda a humanidade, ainda que não o pareça, transcorre sempre, avizinhando-se ao seu destino final.

Em outra passagem são os príncipes que talvez se cansem "em requerer comendas e rendas para muitas vidas!" (VIEIRA, 1993, Vol. I, p. 141). É também a imagem do mundo como um teatro em que as figuras (personagens/atores) sem se darem conta, passam.

O segundo elemento que contêm os sermões do tempo litúrgico do Advento é o tópico do fim da vida e do fim do mundo. A iminência da morte é a marca factual do advento na história e na biografia de cada indivíduo. Acabando-se a vida, finda-se o mundo. Vieira busca alterar por meio de sua prédica os conceitos presentes na imaginação e entendimento de seus ouvintes, para persuadi-los da verdade sobre o Dia do Juízo:

De maneira, senhores, que o conceito que ordinariamente fazemos do Dia do Juízo como uma cousa medonha e espantosa; mas que está lá muito longe, como as serpentes nas areias da Líbia, ou os crocodilos no Nilo, e por isso nos não faz medo. Não é assim: o Dia do Juizo não está longe: está tão perto como o dia de amanhã, e como o dia de hoje, e como esta mesma hora em que estamos: Venit hor, et nunc est. $\mathrm{O}$ vale de Josafat não está só em Jerusalém, nem entre o monte Sião e o Olivete; está em Lisboa, está neste mesmo lugar, e em todos os do Mundo. Se vos tomar a morte no mar, ou na campanha, ou na vossa cama; o mar, a campanha, a vossa cama, é o vale de Josafat: e esse dia, qualquer que for é o vosso Dia do Juízo, ou mais cedo, ou mais tarde; mas dentro deste mesmo século em que nascemos: nom praeteribit generatio haec, donec omnia fiant (VIEIRA, 1993, Vol. I, 146). 
Neste sentido Vieira tangeria uma espécie de "existencialismo" (usando de anacronismo), sobretudo no "Sermão da Primeira Dominga do Advento" de 1652. Na verdade, esta se trata de um sentido herdado pela concepção agostiniana do tempo. Assim, tempo e existência não são coisas necessariamente diferentes, mas aspectos de um mesmo estar no mundo percebido pelo homem. Essa percepção pode ser verdadeira ou falsa, segundo a atuação das potências da alma. A imaginação conduzida pelo amorpróprio leva ao erro de não considerar a própria finitude, enquanto que esta mesma imaginação se conduzida de modo ordenado pelo entendimento proposto pelo pregador desengana o sujeito. A memória deve ser companhia constante, não evadindo o sujeito ao passo, mas conduzindo-o através de seu presente, indicando-lhe o seu futuro, neste caso, o Dia do Juízo. 


\section{Capítulo IV: Raízes históricas}

O capítulo que se segue tratará das raízes históricas que fundamentaram a visão de mundo do seiscentismo. Ao construirmos nossa dissertação, consideramos mais interessante tratar desta temática no final do trabalho, uma vez que optamos por deixar, nos capítulos iniciais, que Vieira se apresentasse por ele mesmo, ou seja, que os elementos dos quais nos propusemos analisar (imaginação e memória) e outros saberes fossem apresentados conforme Vieira os dispõem.

\subsection{A Pregação}

A pregação, do modo que a entendemos, não se constitui apenas como prática social, no âmbito da Igreja católica da Idade Moderna. Também consideramos sua inserção enquanto oratória sagrada no corpo da instituição religiosa. A maneira pela qual é produzida e veiculada é sem dúvida plasmada pela tradição e suas convenções. $\mathrm{O}$ caráter doutrinal e de propagação da fé cristã são substancialmente os sustentáculos desta prática. Há toda uma normatização da pregação no Brasil, segundo os ditames do Concílio de Trento (MASSIMI 2005). Tanto seus atores, quanto o conteúdo dos sermões estavam sujeitos a uma legislação eclesiástica específica, demonstrando assim o reconhecimento da importância desta prática pela instituição, bem como apontando registros de freqüentes transgressões e abusos referentes a esta atividade, necessitando legislá-la (MASSIMI 2005).

No entanto, não nos encontramos em conformidade com a tese historiográfica de que a oratória sagrada deva ser interpretada apenas como uma prática de domesticação das populações, e que a aceitando tais populações se caracterizam como receptores passivos.

Segundo Massimi (2005), tal tese toma corpo já em fins da Idade Moderna através de cronistas, eclesiásticos e intelectuais. Esta leitura se daria parte por influência do iluminismo e parte por um olhar descuidado orientado por presentismo e anacronismo (MASSIMI, 2005). A teatralidade e a busca da mobilização afetiva nos sermões podem ser interpretadas como desinteresse pela convicção racional dos ouvintes, causando assim celeuma com a orientação iluminista de exaltação do conhecimento racional. Do mesmo modo, a persuasão, objetivada pelo sermão, era 
entendida como sujeição dos indivíduos e incorporação de atitudes e crenças consideradas convenientes à Igreja. Hoje, esta visão ainda encontra respaldo em historiadores como Maravall (1997). Porém, outras leituras são realizadas atualmente por especialistas da oratória sagrada moderna como Majorana (1996) e Châtellier (1995). Massimi (2005) resume a interpretação destes últimos autores:

[...] afirmam não ser este o significado do persuadir vivenciado pelo pregador: por exemplo, o desejo de provocar a comoção não seria a única finalidade da encenação piedosa, realizada com o objetivo de teatralizar a prática oratória. Ao invés, pretendi-se tocar a inteligência, de modo a atingir a vontade, conforme o percurso da gnoseologia aristotélico-tomista. Exigia-se, portanto, a coerência intelectual do discurso e uma orde a ser seguida, quer na fala, quer nos gestos. Pois o objetivo era, pelo visível e pelo sensorial, chega à compreensão intelectual, num percurso que alcançaria o espírito passando pela sensibilidade anímica (MASSIMI, 2005, p. 15).

Assim, a pregação se apresenta também como atualização do grande influxo da tradição ocidental. Além da antropologia cristã, inclui-se a forte influência do pensamento helênico e da tradição latina (Cícero, Quintiliano e Sêneca). No Brasil, tudo isso se organiza em uma grande bricolagem, incluindo as peculiaridades do mundo colonial (suas prática e representações) e a influência da visão de mundo da Europa da Idade Moderna. Portanto, um universo conceitual (e suas pertinentes apropriações) se estabelece por meio da pregação. Nas palavras de Massimi(2005):

\footnotetext{
...amplamente valorizada pela população, a pregação assumiu uma função importantíssima de transmissão cultural de conceitos, práticas e crenças da tradição clássica, medieval e renascentista ocidental, visando à mudança dos hábitos e da mentalidade dos indivíduos e dos grupos sociais pela força da palavra (MASSIMI, 2005, p.13).
}

Deste modo, a pregação se converte em instrumento de salvação, tendo a pretensão não apenas de reconduzir o ouvinte a uma postura que lhe garanta a salvação da alma segundo a doutrina. O objetivo é de restabelecer também uma integralidade do sujeito, uma consonância com si mesmo, com a realidade e com a sociedade. Tudo isto poder ser compreendido dentro de uma visão global de saúde, como "medicina da alma”, segundo Massimi (2005):

[...] saúde do corpo animado e espiritual do indivíduo e saúde do corpo político e social. Porque, se é verdade que diversificados e estratificados são os destinatários, por outro lado a pretensão do pregador, pelo uso de sua palavra, é reduzi-los a UM - na medida em que o modelo seguido é o do sacramento eucarístico, em que o Verbo se faz carne, criando o corpo místico na história. A palavra, entendida em suas dimensões doutrinária, persuasiva, evocativa e revelativa, é, portanto, o verdadeiro pharmacon em poder do homem, para que aprenda a bem viver e a bem morrer (MASSIMI, 2005, p. 17). 


\subsection{A Psicologia Filosófica}

A primeira devoção que fazia Santo Inácio todos os dias, era rezar o rosário; e o farol que quis seguissem na teologia as bandeiras da sua Companhia, foi a doutrina de S. Tomás (VIEIRA, 1993, Vol. III, p. 443).

Nos séculos XVI e XVII, a literatura tanto filosófica quanto espiritual propõe-se sistematicamente discutir a interioridade do homem. São desenvolvidas diversas hipóteses e interpretações a cerca da estrutura da alma. Parte-se inicialmente do campo do domínio filosófico, estendendo-se ao território da espiritualidade, "realizando-se assim peculiares formas de enxerto e cruzamentos entre discurso filosófico e espiritualidade" (MASSIMI, 2005, p. 157). Propostas conceituais interpretativas e descritivas são forjadas dentro deste espírito, sendo amplamente veiculados no período. Destacam-se três propostas de estruturação e funcionamento anímico que direta ou indiretamente influenciam os conhecimentos e práticas neste terreno. São eles, o modelo renano-flamengo, o modelo salesiano e o modelo aristotélico-tomista.

O modelo renano-flamengo tem como autor mais representativo Mestre Eckart e estabeleceu-se a partir da mística do Norte da Europa, no século XIV (MASSIMI, 2005):

Tal concepção propõe a existência de três planos do espaço interior: a parte inferior (faculdade sensitiva), a parte média (faculdades racionais) e a parte superior (essência da alma). Este último é o nível propriamente espiritual, em constante relação com o trancendente, chamado também de mente, apesar de se tratar de um plano que vai além da razão. Para este modelo, portanto, a essência da alma, ou espirito, é uma parte distinta do resto da estrutura anímica, hierarquicamente colocada no topo superior (MASSIMI, 1993, p. 163).

O modelo salesiano se origina no século XVII e é proposto por François de Sales em sua obra "Traité de l'amor de Dieu" de 1616:

Para Sales, em suma, três grandes forças apetitivas interagem na alma humana: a vontade, o apetite sensitivo e as propriedades ocultas e secretas (simpatia e antipatia) próprias a todos os seres vivos - as quais não são precedidas por nenhum tipo de conhecimento. Portanto, a alma articula-se em três planos: sensorial, racional superior e racional inferior, originando uma tópica multiplanar do espaço interior (MASSIMI, 2005, p. 165). 
Porém, o "modelo aristotélico-tomista, que [...] funda suas raízes nas obras de Aristóteles e Tomás de Aquino, e é transmitido ao longo dos séculos pelos tratados de escolástica, é ainda o mais difundido no século XVII" (MASSIMI, 2005, 157).

Através da cultura árabe, que em determinado momento da história tem grande influência na Europa, a obra de Aristóteles é redescoberta e atualizada para o contexto ocidental (REALE e ANTISERE). Os pressupostos filosóficos aristotélicos vão ao encontro de muitas das bases do cristianismo, encontrando em grandes nomes como Alberto Magno respaldo e propagação.

Mas, é em Tomás de Aquino ${ }^{21}$, um dos discípulos de Alberto, que os conceitos aristotélicos melhor se assentaram para produzir a base de um modelo filosóficoteológico, o qual tem forte influência até hoje.

Tomás de Aquino, recapitulando Aristóteles, desenvolveu todo o seu pensamento dentro das concepções de tripartição da alma humana. Para ele, o equilíbrio consiste na alma racional dominar as demais (virtude ética em Aristóteles), formação do hábito enquanto segunda natureza humana e o conceito do "Bem último", atualizado por Tomás, segundo o contexto cristão, associa este ao conceito monoteísta de um Deus criador. Todavia, o que o difere de Aristóteles em alguns pontos importantes é, principalmente, a interpretação do conceito de alma dos gregos. Reale e Antiseri (1990) afirmam:

\begin{abstract}
Em suma, desde Sócrates, os gregos passaram a ver na alma a verdadeira essência do homem, não sabendo pensar o homem senão em termos de corpo e alma - e toda a tradição platônica, pitagórica e o próprio Aristóteles (e, portanto, a maior parte da filosofia grega) consideram a alma imortal por natureza. Ora, a mensagem cristã propôs o problema do homem em termos completamente diferentes. Nos textos sacros, o termo 'alma' não aparece nas acepções gregas. $\mathrm{O}$
\end{abstract}

\footnotetext{
21 Nascido em Roccasecca, no sul do Lácio, em 1221, filho de um poderoso feudatário, Landolfo, conde de Aquino. Junta-se a ordem dos Dominicanos, a qual por ser de fundação ressente e voltada à pregação nas classes populares, não gozava de grande prestígio. Estudou filosofia em Nápoles e depois em Paris, onde se dedicou ao ensino e ao estudo de questões filosóficas e teológicas. Estudou teologia em Colônia e em Paris se tornou discípulo de Alberto Magno que o "descobriu" e se impressionou com a sua inteligência. Por este tempo foi apelidado de "boi mudo" devido seu caracter introvertido e sua compleição física. Foi mestre na Universidade de Paris no reinado de Luís IX da França morrendo, com 49 anos, na Abadia de Fossanova, quando se dirigia para Lião a fim de participar do Concílio de Lião, a pedido do Papa. "Expoente entre os escolásticos, verdadeiro gênio metafísico e um dos maiores pensadores de todos os tempos, Tomás de Aquino elaborou um sistema de saber admirável pela transparência lógica e pela conexão orgânica entre as partes, de índole mais aristotélica do que platônico-agostiniana" (REALE e ANTISERI, 1990, p. 552). Alberto diz certa vez a respeito de seu discípulo reconhecendo-lhe a inteligência: "Este moço que nós chamamos de 'boi mudo', mugirá tão forte que se fará ouvir no mundo inteiro!".
} 
cristianismo não nega que, com a morte do homem, sobreviva algo dele; pelo contrário, fala expressamente dos mortos como sendo recebidos no 'seio de Abraão'. Entretanto, o cristianismo não aponta em absoluto para a imortalidade da alma, mas sim para a 'ressurreição dos mortos'. Essa é uma das marcas da nova fé. E a ressurreição implica no retorno também do corpo à vida (REALE e ANTISERI, 1990, p. 392).

Em Aquino, a grandeza do homem se dá através da ação (nas obras), enquanto que em Aristóteles a grandeza está no conhecimento; também para Tomás a instância mais elevada do homem constitui-se no espírito e não na alma racional aristotélica. Da mesma forma, o conceito de liberdade dada através do livre-arbítrio só é possível dentro da concepção cristã, sendo inconciliável com o fatum grego, onde não há como fugir das teias do destino, muito bem retratado nas tragédias gregas.

Com a ideia de um Deus único e criador, o qual pode se manifestar através da revelação - elemento também inexistente no universo grego - Tomás de Aquino prega a fé enquanto complemento da razão e a teologia enquanto aperfeiçoamento da filosofia.

Em sua "Suma Teológica", Tomás de Aquino para sedimentar sua "filosofia teológica" utiliza todo este universo aristotélico-cristão, através do método escolástico, que consiste em linhas gerais em argumentação e contra argumentação de preceitos propostos.

Aquino diz que a intenção do pregador é criar um novo hábito no ouvinte "vencer", para Agostinho (1991) - porém, diferentemente de Agostinho, Tomás de Aquino não apoia a posição segundo a qual, através do uso da retórica deve-se convencer o ouvinte em nome da verdade. Defende o reconhecimento da verdade pelo intelecto e assim a liberdade do sujeito: "É pelo mesmo fundamento que dizemos ser uma virtude o bom uso do livre arbítrio; pois, para ele, como para o seu ato próprio, se ordena a virtude. Pois, um ato de virtude não é mais que o bom uso do livre arbítrio" (REALE e ANTISERI, 1990, p. 397).

Ainda em na "Suma Teológica" (AQUINO, 2002), Tomás de Aquino articula uma concepção do dinamismo das paixões baseada em Aristóteles, onde estas se diferenciam e se relacionam de formas diversas com seus respectivos objetos.

Estas três dimensões são do âmbito de como se dá o conhecimento, e não uma divisão do ser humano. Para Aquino, o homem é um sínolo, ou seja, indissociavelmente corpo e alma, onde o espírito estaria incutido na alma racional. 
A alma adquire um novo status; sendo o "espírito" a possibilidade de o homem transcender ao mundano e ao sensível, e o "corpo" representar o "estar no mundo" do homem e ser fonte de conhecimento (o homem pode conhece através do sensível), a alma tem quase que uma função integradora do homem; é ela que estabelece os vínculos entre as dimensões do homem. É a alma o lugar onde a pessoa apreende o mundo e o transcende. Sendo assim, Tomás traz para a acepção cristã a visão aristotélica. O objetivo de Tomás de Aquino não é adulterar a obra de Aristóteles, mas retirar os obstáculos à fé cristã não evidentes nos escritos dele ${ }^{22}$.

Na concepção aristotélico-tomista, a alma se "subdividiria" em três partes: alma vegetativa; alma sensitiva e alma racional.

A alma vegetativa é o princípio elementar em todos os seres vivos, princípio que governa e regula as atividades biológicas. Exerce-se no órgão corpóreo e junto a ela estão presentes as potências vegetativas: nutritiva (alimentar), aumentativa (crescer), geratriz (reproduzir) (REALE e ANTISERI, 1990).

A concepção de alma sensitiva parte da ideia de que os seres vivos possuem funções que vão além das potências vegetativas, como sensações, apetites e movimento. Então, torna-se necessário outro princípio que regeria tais funções, o qual corresponde à alma sensitiva. É o que afirmam Reale \& Antiseri (1990, p. 200): “com efeito, na assimilação que se dá na nutrição é assimilada também a matéria, ao passo que na sensação é assimilada apenas a forma” (REALE; ANTISERI, 1990, p. 200): a alma está presente tanto nos animais, quanto no homem - animal racional.

Junto a esta parte da alma, estão as potências sensitivas, as quais se dividem em externas e internas. Tem-se nas externas uma relação imediata com a alma vegetativa, pois estas são cinco (visão, audição, olfação, gustação e tato) e se relacionam diretamente com os respectivos órgãos corpóreos dos sentidos, ou seja, "quando um sentido capta um sensível próprio, então a respectiva sensação é infalível" (REALE \& ANTISERI, 1990, p. 200).

Já as potências internas seriam em quatro: senso comum, imaginação, cogitativa e memorativa. Tomás as descreve em sua Suma Teológica:

Assim pois, o sentido próprio e o comum ordenam-se a receber as formas das coisas sensíveis. Será dito adiante como eles distinguem. -

\footnotetext{
${ }^{22}$ Segundo Gilson (1962): "Rigorosamente falando, não é exato dizer que Tomás batizou Aristóteles. Ao contrário, em todo lugar em que Aristóteles ou contradiz a verdade cristã (eternidade do mundo) ou simplesmente a desconhece (criação ex nihil), frei Tomás ou o diz com franqueza, ou, ao menos, não lhe atribui o que ele não disse de modo expresso [...]. Por exemplo, é notável que, ao comentar a Metafísica de Aristóteles, na qual a causalidade do Primeiro Motor é tão importante, Tomás de Aquino não usou uma vez sequer a palavra criação" (GILSON, 1962, p. 9,10).
} 
Para reter ou conservar essas formas, ordena-se a fantasia ou imaginação que são uma mesma coisa. A fantasia ou imaginação é, com efeito como um tesouro das formas percebidas pelos sentidos. Para apreender as intenções que não são percebidas pelo sentido, ordena-se a estimativa. - Para conservá-las, a memória, que é como um arquivo delas. É sinal disso que o princípio da lembrança nos animais resulta de tal intenção. Por exemplo, que isto é prejudicial ou é conveniente. E a mesma razão de passado, pela qual responde a memória, deve ser contada entre essas intenções (AQUINO 2002, p. 432).

Porém, há uma distinção entre os animais e o homem na maneira como atuam algumas potências. O nível perceptivo, ou seja, a maneira pela qual os dados da realidade são colhidos e internalizado é o mesmo para homens e animais. No entanto, o nível de intencionalidade, de significado imediato, de apercepção destes mesmos dados, é distinto. Aquino assinala a diferença entre a potência estimativa dos animais e a potência cogitativa dos homens, também amplia a função da potência memorativa no homem acrescentando-lhe como faculdade a reminiscência, que não apenas fornece a lembrança imediata, mas proporciona a capacidade investigativa da memória dos fatos:

\begin{abstract}
Ainda se deve considerar que, em relação às formas sensíveis, não há diferença entre o homem e os animais. São modificados da mesma maneira pelos objetos sensíveis exteriores. Mas, quanto a essas intenções, há uma diferença. Os animais as percebem apenas por um instinto natural; o homem também por uma espécie de comparação. Por isso, a potência que se denomina nos animais de estimativa natural é chamada no homem de cogitativa, porque descobre essas intenções por uma espécie de comparação. Chama-se, ainda razão particular, e os médicos lhe destinam um órgão determinado, a parte mediana do cérebro. Reúne comprando as representações individuais, como a razão intelectiva compara as intenções universais. - Quando à memorativa, o homem não só possui a memória, como os animais, com a qual se lembra imediatamente dos fatos passados, mas também possui a de reminiscência, com a qual, de uma maneira quase silogística, investiga a memória desses fatos, enquanto são intenções individuais" (AQUINO, 2002, p. 432).
\end{abstract}

Esse universo do sensível de orientação aristotélico-tomista é retomado posteriormente e redefinido, pela Segunda Escolástica, elaborando de uma forma mais refinada a articulação entre as potências sensitivas, as quais produzem o conhecimento. A partir de meados do século XVI, declina o Humanismo e fortalece-se a influência dos padres da Companhia de Jesus. Coube a estes desenvolver o que se convencionou chamar de "A Segunda Escolástica" Portuguesa, a qual foi exposta nos diversos textos da obra coletiva conhecida como Cursus Conimbricensis:

[...] redigidos pelos professores do Colégio das Artes da Companhia em Coimbra, e que, posteriormente, foram utilizados para os estudos filosófico nos colégios da Companhia no Brasil. Os tratados são 
comentários das obras aristotélicas. No caso do estudo antropológico e psicológico, evidenciam-se os seguintes textos: o comentário ao tratado De Anima (Sobre a Alma, Gois, 1602), o comentário ao tratado Parva Naturalia (Pequenas coisas Naturais, Gois, 1593a), o comentário ao tratado Ética a Nicômaco (Gois, 1593b), o comentário ao De Feneratione e Corruptione (Sobre a geração e a corrupção, Gois, 1607) (MASSIMI, 2005, p. 165).

Em síntese, seus autores conseguiram fundir até onde isto foi possível, o Humanismo e a Escolástica. Do Humanismo os jesuítas utilizaram os métodos críticos e filológicos para restaurar a versão latina de Aristóteles e partilharam da sua rejeição à escolástica decadente, sobretudo a dos nominalistas e dos naturalistas italianos do século XV. Com a Segunda Escolástica Portuguesa, tem-se, a partir da segunda metade do século XVI, uma Escolástica integrada no ambiente do Humanismo, mas também um Humanismo integrado na Escolástica (FALCON, 1997).

Torna-se este o referencial interpretativo oficial da Companhia de Jesus. Zanlonghi (2003) descreve a articulação de tal modelo, onde entre os quatro sentidos internos cabe a cogitativa um papel bastante particular. Enquanto o senso comum produz a primeira unificação das informações sensíveis, a fantasia, mesmo movendo-se ainda no âmbito das 'res sensatas', inicia o processo de unificação na dispersão espaço temporal; todavia é somente com a cogitativa que se constitui um quasi thesaurus specierum, capaz de conjugar, conectar, e dignoscere res non sensatas (ZANLONGHI, 2003).

Desta maneira, com a potência cogitativa, o conjunto das informações sensíveis recebe uma nova e mais estável síntese; a cogitativa constitui-se como o ápice da organização da atividade sensitivo-imaginativa. Além do mais, essa é, segundo a lição de Tomas, ratio particularis, ou seja, mesmo pertencendo ao âmbito pré-racional, já se apresenta orientada ao universal. Colocada no limite com o intelecto, a cogitativa colhe, sem ainda conhecê-lo enquanto tal, o universal.

Zanlonghi (2003) também indica conseqüências desta maneira de estruturar o universo anímico. Antes de qualquer coisa, fica eliminado o equívoco a cerca da passividade dos sentidos: esses, mesmo não operando discursivamente, concorrem ativamente para a intelecção. O intelecto agente age nos fantasmas, dá uma iluminação que o embebe de si. O estatuto "quase universale" do fantástico não se torna contraditório justamente quando não se interpreta dualisticamente a relação sensibilidade/intelecto, e pressupõe, ao contrário, um patrimônio imaginativo não 
fechado no âmbito do sensível, na medida em que já é tocado pela luz do inteligível (ZANLONGHI, 2003). Sensibilidade e intelecto interagem até o ponto em que estreita afinidade com o espírito.

Tem-se, por final, a alma racional - para os gregos o que definia o homem, pois "o órgão dos sentidos não existe sem o corpo, enquanto a inteligência existe por sua própria conta" (Aristóteles conforme citado por REALE e ANTISERI, 1990, p. 200) onde estaria situada a capacidade do inteligir, a vontade, a capacidade de elaborar um juízo acerca da realidade, e de apreender a intencionalidade das formas universais. Diferentemente dos gregos, Tomás de Aquino toma o Intelecto como "uma potência da alma e não a essência mesma dela" (AQUINO, 2002, p. 198). Assim a alma racional não se aparta das outras esferas anímicas: por exemplo, não pode prescindir do sensível, pois "o pensamento humano é ligado à sensibilidade; o intelligere compreende a sensibilidade, não pode prescindir dela: como Tomás havia já dito, conhecer é ter uma visão nos dados sensíveis" (ZANLONGHI, 2003, p. 68).

Deste modo, a dinâmica interna do homem poderia ser definida como uma "monarquia espiritual", na qual a vontade "exerceria soberania sobre os demais membros e faculdades e o entendimento é seu conselheiro, o qual representa os objetos espirituais a ser amados e a feiura dos vícios a ser aborrecidos” (MASSIMI, 2005, p. 162).

Porém, atribui-se grande importância a esfera do sensível, do corporal e do préracional:

Neste projeto retórico espelha-se assim a unidade da pessoa irredutível a uma única dimensão: a palavra é análoga a alma, e a imagem ao corpo do discurso. Na verdade, a antropologia filosófica aristotélica unitária, contraria ao dualismo entre forma e substância, comportava uma psicologia atenta a descrever e reconhecer as múltiplas interações entre o intelecto e a paixão, entre a racionalidade e a afetividade. As frequientes metáforas corpóreas utilizadas na esfera da linguagem atestam este fundamento (Massim, 2005, 96)

\subsection{Retórica}

Emersa em uma cultura marcada pela oralidade, a pregação toma corpo através do discurso articulado e eloquente. A palavra bem enunciada constitui-se elemento de valorização social no Brasil colônia. Vale ressaltar que o primeiro contato das culturas europeia e indígena encontrou denominador comum na capacidade argumentativa. Já em 1593 o jesuíta Fernão Cardim (1548-1625) - visitador da Companhia de Jesus no 
Brasil - relata o que ele refere como pregação entre os índios (MASSIMI 2005). O que se vê é uma descrição por parte do jesuíta da grande valorização da fala entre os índios, de seu poder de coesão social e de deliberação. Massimi (2005) comenta:

Cardim continua o relato, afirmando que entre os índios principais e pregadores "há alguns velhos antigos de grande nome e autoridade entre eles, que têm fama por todo o sertão, trezentas e quatrocentas léguas, e mais". Afirma que os nativos estimam tanto "um bom língua que lhe chamam o senhor da fala. Em sua mão tem a morte e a vida, e os levará por onde quiser sem contradição". Quando eles querem testar se um indivíduo possui esta capacidade, "ajuntam-se muitos para ver se o podem cansar, falando toda noite em peso com ele, e às vezes dois, três dias, sem se enfadarem (MASSIMI 2005, p. 23).

Por outro lado, também a cultura europeia se encontrou em um movimento expansivo no sentido da comunicação. A expansão marítima proporcionou de certo modo, um descentramento europeu no que diz respeito a sua antropologia filosófica. Novas terras, com novos povos provocam a necessidade de rever a noção de homem, mesmo para nominar a alteridade encontrada no Novo Mundo. Deste modo, a palavra se apresenta na perspectiva de:

...inesperado ponto de convergência entre a cultura desconhecida
dessas populações e o imenso esforço de comunicação da cultura
européia daquela época, evidente na criação de novos instrumentos,
como a imprensa, na busca de contatos e conhecimentos de novos
povos, novas culturas e novas línguas e [...] no grande
desenvolvimento da arte retórica e das suas infinitas possibilidades
como meio pedagógico e doutrinário (MASSIMI, 2005, p. 17).

A retórica tornou-se meio fecundo para o exercício da eloquência e seus desdobramentos. É a palavra laboriosa que perpassa toda a estrutura do homem psique, materialidade e transcendência - e a articula de forma conjunta e unitária, integrando-a.

Por isso a palavra persuade: promove uma identificação entre pregador, o outro e o mundo, numa dinâmica intersubjetiva, onde é exigido do pregador um conhecimento de si mesmo, para então entrar em "diálogo" com a afetividade do outro, se identificando e se fazendo identificar. A palavra ao desenganar, restitui o valor ético da ação humana - a morada própria do homem, um modus vivendi -, promovendo a integração da estrutura humana, o homem total do século XVII (GONTIJO; MASSIMI, 2007). Assim, temos que: 
Uma vez compreendida a pregação como prática cultura, passa-se a considerá-la enquanto laboratório de experimentação do poder da palavra - numa perspectiva que num certo sentido remete à atual compreensão psicanalítica e psicológica moderna da eficácia terapêutica da palavra, mas que, no caso da Idade Moderna, deve ser reconduzida principalmente à aplicação da arte retórica. A partir dessa ótica, aborda-se também a função da palavra em seu papel de transmissora de conhecimentos e evocativa de afetos, e, para tanto, realiza-se um excursus dentro da gnosiologia e da psicologia da época (MASSIMI, 2005, p. 17).

É no âmbito do desenvolvimento da arte retórica que a pregação enquanto oratória sagrada se constitui. Toda uma tradição da oratória profana, de origem grega e latina, é apropriada pelo contexto cristão. De longa data, figuras de referência como Agostinho de Hipona (354 - 430) incorporam a arte e o conhecimento da oratória para buscar a conversão dos ouvintes. Autores clássicos como Aristóteles, Sêneca e Cícero tornaram-se tradicionalmente mananciais da arte da eloqüência dentro da instituição religiosa. Conseqüentemente toda esta tradição ressoa nos sermões de Vieira.

A seguir, faremos uma breve exposição sobre concepções de retórica e seus artifícios, apresentadas por alguns expoentes autores de grande influência na pregação do século XVII ${ }^{23}$.

\subsubsection{Aristóteles}

Aristóteles procura distinguir a retórica de outras formas de conhecimento, como por exemplo, a ciência, pois a retórica procura persuadir, raciocinar sobre verossimilhança e opiniões, ao passo que a ciência demonstra.

O filósofo toma a retórica como parte integrante do relacionamento entre os homens. Quando acusamos alguém de algo ou vamos a sua defesa, quando expomos ideias aos outros, ou questionamos as idéias destes, usamos de retórica. Aristóteles

\footnotetext{
${ }^{23}$ Os autores latinos (Cícero, Sêneca e Quintiliano) não foram diretamente contemplados nesta seção. Porém, entende-se que estes são necessariamente apropriados pelos autores da oratória religiosa. No entanto vale ressaltar a influência de Cícero: "Marcam o início da retórica latina dois tratados completos: o De inventione, um tratado de juventude de Cícero (c. 87 a.C.), e o Rhetorica ad Herennium - durante muito tempo atribuído a Cícero, mas de autoria incerta -, nos quais se firma a tradição de um sistema retórico que permanecerá até praticamente fins do século XVIII. Em face do descrédito a que fora relegada a retórica como resultado das acusações platônicas e das atividades dos sofistas, o programa ciceroniano visou restabelecer seu estatuto não apenas como arte, mas como arte das artes - "uma visão do mundo, uma concepção global da cultura, na qual a retórica encontra um papel centralizador e unificador", resume Barilli (1985, p. 41). A questão da moldura ética e política ou técnica da retórica é retomada numa forma nitidamente prática, que se harmoniza perfeitamente com o caráter sistematizador da tradição iniciada por Hermágoras (II d.C.): as responsabilidades cívicas, o trato da res publica (negotium) têm precedência sobre as especulações teóricas e metafísicas (otium)” Dobranszky (2005) .
} 
consegue distinguir e sistematizar os recursos que os estilos e meios oferecem ao orador:

\begin{abstract}
A Retórica não deixa de apresentar analogia como a Dialética, pois ambas tratam de questões que de algum modo são da competência comum de todos os homens, sem pertencerem ao domínio de uma ciência determinada. Todos os homens participam, até certo ponto, de uma e de outra; todos se empenham dentro de certos limites em submeter a exame ou defender uma tese, em apresentar uma defesa ou uma acusação. A maioria das pessoas fazem-no um pouco ao acaso, sem discernimento; as restantes, por força de um hábito proveniente de uma disposição. Como de ambos os modos se alcança o fim almejado, é obvio que se poderia chegar à mesma meta seguindo um método determinado. Atendendo a que são igualmente bem-sucedidos tanto os que procedem por hábito como os que atuam espontaneamente, é possível investigar teoricamente a causa do êxito. Ora, todos convirão facilmente ser esse o objetivo próprio de uma Arte (ARISTÓTELES, 1994, p. 31).
\end{abstract}

Apesar da retórica não tratar dos princípios da moral, pois isso cabe à Ética, não cai nas extravagâncias tanto de estilo como de valores em que caem os sofistas. Toda a obra de Aristóteles é um constructo conciso. Daí sua concepção de retórica passar pela ideia de meio termo o qual o impede de privilegiar a forma em relação ao conteúdo, e não separar o pensamento do seu invólucro verbal, não se fazendo valer a forma como propunham muitos sofistas (REALE; ANTÍSERI, 1990).

\title{
5.3.2 Agostinho de Hipona
}

Agostinho, considerado um dos Doutores da Igreja (Doctor Gratiae), foi também grande orador e professor de retórica. Referncia na arte da oratória sagrada torna-se modelo e propõe princípios amplamente adotados na pregação. Em seu livro IV da Doutrina Cristã, encontramos a fundamentação para a utilização em âmbito religioso de técnicas retóricas destinadas a atingir o universo psíquico dos ouvintes, para propiciar a compreensão, a persuasão e a conseqüente modificação das condutas. Agostinho também propicia um importante entendimento de quem é o pregador e qual sua função:

O pregador é o que interpreta e ensina as divinas Escrituras. Como defensor da fé verdadeira e adversário do erro, deve mediante o discurso ensinar o bem e refutar o mal. Nesta tarefa, o mestre deve tratar de conquistar o hostil, motivar o indiferente e informar o ignorante sobre o que deve ser feito ou esperado. Mas ao encontrar ouvintes benévolos, atentos, dispostos a aprender ou que os tenha 
assim conquistado, ele deverá prosseguir seu discurso como pedem as circunstâncias (AGOSTINHO, 1991, p. 147).

Observamos aqui que é implícito à função do pregador alterar e/ou conduzir a dinâmica dos afetos dos ouvintes para que este ponha sua vida em coerência com as idéias reconhecidas como verdadeiras. Sendo que para isso "são necessárias exortações invectivas, movimentos vivos, reprimendas e todo outro procedimento capaz de comover os corações" (AGOSTINHO, 1991, p. 149), além de que ele convença com raciocínios apoiados em provas, ou seja, orador cristão deve lançar mão de todos os recursos da arte retórica para persuadir.

Nota-se o cuidado que Agostinho possui para introduzir o tema do método e de sua importância, para que este não seja valorizado em demasia. Para tanto, o autor desenvolve uma argumentação acerca da primazia do conteúdo em relação à forma. Assim, a sabedoria é mais importante que a eloquência, o testemunho de vida do pregador mais importante que sua pregação, e a oração, a inspiração divina e a própria importância por si da Palavra divina são o que devem ser transmitidos.

Agostinho se fundamentando em Cícero ${ }^{24}$, indica que os objetivos do discurso seriam instruir, agradar e convencer. Depois, acrescenta: Instruir é uma necessidade; agradar, um prazer; convencer, uma vitória (AGOSTINHO, 1991). Aqui Agostinho sintetiza a dinâmica que ele considera ser própria da pregação. O que é efetivamente necessário na pregação é a clarificação do que vem a ser a verdade: para se tomar um partido sobre algo se torna fundamental saber do que se trata. É necessário instruir.

Porém, muitas vezes, para se instruir é preciso manter a atenção do espectador e para isso a fala deve ser aprazível, torna-se importante uma boa estruturação "estética" do discurso, utilizando-se de recursos linguísticos para agradar. E o convencimento torna-se o objetivo final. O ouvinte deve tomar para si do que foi agradavelmente instruído e então alterar seu comportamento, criar um novo hábito (no sentido aristotélico), deve se convencer:

Isso porque para suceder bem, o que importa é a maneira de dizer. Ora, assim como é preciso agradar ao auditório para o manter na escuta, também é preciso convencê-lo para o levar à ação. E assim como o auditório sente prazer se tu falas de modo agradável, também ele se convence se gostar do que lhe propõe, se temer aquilo de que o ameaças. Se odiar o que reprovas; se abraçar o que recomendas; se deplorar o que excitas a ser deplorado; se sentir alegria com o que

\footnotetext{
${ }^{24}$ De Oratore, orginial do séc. I a.C.
} 
anuncias ser motivo de regozijo; se tiver piedade dos que apresentas como dignos de piedade; se fugir dos que incitas a evitar. Ora, esses efeitos e todos os outros que exigem grande eloqüência não têm a não ser uma única finalidade: tocar o espírito dos ouvintes não para saberem o que tem de fazer, mas para que se determinem a cumprir o que já sabem ser de seu dever (AGOSTINHO, 1991, p. 150).

Neste último trecho citado está descrita, em síntese, o que, para Agostinho, é a proposta da persuasão e dissuasão da pregação: transformar as palavras e os gestos do pregador em novas condutas por parte do auditório, através do movimento dos afetos e outras instâncias da alma e da consciência do ouvinte.

Agostinho chama a atenção para o cuidado que o pregador deve ter com a comunicação travada com o auditório: é necessária uma clareza bem maior por parte do orador, pois não há a proposição de perguntas e pedidos de explicação nesse tipo de comunicação, "assim quem fala deve tomar o maior cuidado de vir em ajuda de quem se cala" (AGOSTINHO, 1991, p. 151). O pregador deve perceber a dinâmica do lugar e situação onde está, e então notar, através do comportamento, as mostras que o auditório lhe dá de que houve o estabelecimento da comunicação.

Diz Agostinho, "ordinariamente, o povo na sua avidez de entender costuma dar demonstração, por seus movimentos, de que compreendeu" (AGOSTINHO, 1991, p. 151). Quando Agostinho estabelece um estilo de discurso - simples, temperado ou sublime - define também modalidades de comunicação pelos quais são tratados determinados assuntos em dados momentos. Nesta perspectiva, ele considera a função de processos "psicológicos" como memória, atenção e compreensão:

Se for empregado um só estilo, seja o simples, por ser o mais fácil e suportável por mais tempo do que o estilo sublime. Pois quando mais vivamente nós pretendemos convencer a alma pra obter 0 consentimento do ouvinte, por menos tempo conseguimos, mante-lo nessa tensão, após ter sido suficientemente excitado. E assim, devemos nos prevenir de querer elevar alto demais o que já fora elevado, receio que não venha a decair do ponto onde a eloqüência o tinha elevado. Mas ao intercalar as passagens dita em estilo simples com as passagens que é preciso dizer em estilo sublime, pode-se de novo voltar a esse e, assim, o movimento do discurso se faz como com as ondas agitadas do mar. Conseqüentemente, o estilo sublime, caso seja necessário empregá-lo por muito tempo, não deve ser empregado sozinho, mas variando-o com a intercalação de outros estilos (AGOSTINHO, 1991, p. 158).

Assim Agostinho propõe um modelo de retórica a ser empregado na pregação, que justifica o uso pleno desta arte com toda a sua potencialidade para convencer o ouvinte e "vencer", fazendo com que este passe do afeto e compreensão para a ação. 


\subsubsection{Tratado de Retórica de Luiz de Granada}

"Aquele grande varão, doutíssimo e religiosíssimo, o padre Frei Luís de Granada, dizia: que uma das maravilhas que Deus fez no mundo, foi Santo Inácio, e o seu Instituto.” (VIEIRA, 1993, Vol. III, p. 425)

Todas essas ideias, e significações, referentes à retórica e ao funcionamento da alma - essa visão de mundo - são retomadas e de certa forma compilados em manuais, melhor dizendo em tratados de pregação, os quais se tornam a base metodológica dos Sermões da época.

Um exemplo significativo é a obra do Frei Luís de Granada ${ }^{25}$ (1505-1588). Este, recapitula em sua obra “Los Seis Livros De La Retorica Eclesiástica O Dela Manera De Predicar" as propostas de Agostinho e Cícero.

O livro foi escrito em língua latina e posteriormente traduzido para o espanhol. Utilizamos a edição espanhola da Biblioteca dos Autores Cristianos, Tomo terceiro, 1945. Refere-se a Santo Agostinho ${ }^{26}$ e a Cícero $^{27}$ para fundamentar a afirmação de que a arte do bem falar deve ser aprendida na juventude e será assimilada com tanta maior facilidade quanto mais os alunos estiverem imbuídos pelas ciências dialéticas e filosóficas.

Por isto, justifica a necessidade de recorrer ao estudo da arte retórica:

Para tratar desta arte do bem dizer, foi necessário recolher alguns preceitos das oficinas dos retóricos, tendo a finalidade que o ensino desta arte, assim como as demais, serve também à teologia sagrada e ao ministério da palavra divina (GRANADA, 1945, p. 489, trad. nossa).

Muito importante também é o Prólogo do Autor, onde este afirma que, tendo dedicado dez anos de sua vida à atividade de escrever sermões, avaliou o fruto de este trabalho ser escasso, por descuidar de uma parte importante das funções do pregador: a pronúncia.

Granada (1945) coloca a seguinte concepção de Retórica:

Retórica é uma arte de bem falar ou uma ciência de falar com prudência e adorno acerca de qualquer assunto. Pois apesar do nome retórica significar a parte da eloquência que contém apenas os preceitos da arte, aqui nós consideramos a retórica como a eloquência, que é a habilidade de explicar com prudência, com clareza, com

\footnotetext{
${ }^{25}$ O teólogo e pregador espanhol, Luís de Granada, foi mestre da arte da palavra a serviço da evangelização, constituindo-se em modelo exemplar para várias gerações de pregadores católicos, em seus tratados, elaborara articulações explicitas entre os domínios da retórica sagrada e do conhecimento de si mesmo.

${ }^{26}$ De Doutrina cristiana, liv. 4 , cap. 3

${ }^{27}$ De Oratoribus, liv. 1, cap. 3
} 
abundância e com harmonia: isto é eloquência que não vem a ser outra coisa do que uma sabedoria que fala copiosamente.

[...] Dizemos que a matéria de uma arte é aquela em que se exercita toda a arte e a faculdade que se forma pela arte. Por isto, assim como dizemos que a matéria da medicina são as enfermidades e as feridas, pois delas trata toda a medicina, chamamos matéria da arte retórica as coisas de que trata a arte e a faculdade da oratória (GRANADA, 1945, p. 506, trad. nossa).

São três os ofícios principais do perfeito pregador: a invenção, o falar, o pronunciar. À invenção pertence o falar sentenças esclarecidas e significativas, acomodadas a um determinado designo; desse modo, o discurso do pregador será adequado, o que é a virtude principal da invenção. À elocução cabe explicar de modo conveniente toda a força da sentença e declarar com as palavras os sentimentos do animo, de modo que aquilo que ele mesmo concebe, ao falar o infunda nos ânimos dos ouvintes. "À pronúncia cabe acomodar a voz, o gesto, e o rosto à coisa dita" (GRANADA, 1945, p. 490, trad. nossa).

Granada (1945) evidencia que o ofício do pregador depende da caridade, pois dela procede ao ardor pela glória de Deus e pela salvação das almas, que é o principal fundamento do ofício do pregador. Este divino ardor, segundo o frei, ajuda mais o pregador do que todas as escolas e os preceitos dos retóricos:

Pois este afeto, por si só, é como a mente e a alma deste artifício, dando ao pregador quase todo o que ele precisa. [...] Este divino ardor obriga a buscar todos os modos de persuadir e mover o coração, a adaptar todas as 'máquinas' ao entendimento dos ouvintes, para infundir-lhes o temor de Deus, e move-los ao aborrecimento do pecado e da vida ruim. Este ardor, quando oferece-se a ocasião, move afetos poderosos, dá documentos admiráveis para o bem viver, levanta com acrimônia e energia os ânimos decaídos dos ouvintes e desperta os que dormem. Este ardor exclama, argumenta, roga, repreende, espanta, pasma, admira-se e transforma-se em todos os afetos e figuras do dizer. Ressuscita os mortos, fala aos ausentes, implora o auxílio de Deus, mistura céus, terras e mares (GRANADA, 1945, p. 502, 503, trad. nossa).

O pregador que possui a caridade discorre de modo tal que:

Imprime nos ânimos dos ouvintes aquele afeto que antecipadamente manifesta nele mesmo, com a voz, com o semblante, com o gesto, com a acrimônia e valentia no dizer (GRANADA, 1945, p. 503, trad. nossa).

\subsubsection{Cipriano Soares}

Durante a formação nos colégios da Companhia de Jesus, algumas obras se tornaram extremamente relevantes. Estas compuseram a base da formação de 
humanidades clássicas durante mais de dois séculos na Europa moderna28. Dentre elas é notória a obra de Cipriano Soares ${ }^{29}$, De Arte Rhetorica libri tres (1580).

Em dado momento, devido à expansão dos colégios da Companhia de Jesus e sua demanda educacional, foi solicitado que alguns mestres elaborassem compêndios de suas aulas e estes fossem dados à estampa. De maneira pedagógica, a arte retórica foi amplamente veiculada através do compêndio de Soares, elaborado quando este era professor de Retórica no Colégio das Artes em Coimbra. A obra torna-se o manual de base para o ensino de retórica nos Colégios da Europa, do Brasil e do Oriente. Sua disseminação e influência é comentada por Miranda (2001):

\begin{abstract}
A prescrição da Retórica de Soares na Ratio de 1599 era o reconhecimento de uma popularidade crescente que a obra vinha alcançando em dezenas de colégios. Embora o seu uso não fosse obrigatório, era recomendado pelos autores da Ratio, e tal facto não pôde deixar de lhe conferir uma autoridade incontestável, o que lhe viria a valer mais de duzentos anos de vigência e atualidade. Com efeito, a Bibliothèque de La Comapgnie de Jésus de Sommervoge, não sendo um trabalho exaustivo, registra, em cerca de 200 anos, 150 edições, em dezenas de cidades da Europa, mas estudos posteriores já elevaram o número de reimpressões a pelo menos 207, em diversos pontos da Europa. Um livro tão largamente divulgado com este exerceu necessariamente uma influência bastante significativa nas instituições que o adoptaram, nomeadamente nos colégios da Companhia (MIRANDA, 2001, p. 120).
\end{abstract}

A concepção de retórica dada por Soares (1580) em seu compêndio tem função pedagógica. Não se trata de compreender a retórica enquanto uma técnica a ser transmitida, mas sim um meio pelo qual, através do processo de comunicação, o sujeito pode desenvolver suas potencialidades humanas e se relacionar com o corpo social em que se insere. Expressando assim, toda uma tradição que a perfaz, segundo Massimi (2005):

O compêndio de Cypriano Soares, que devia ser decorado conforme preceitos da Ratio Studiorum, propõe o método da imitação, com o ensino da retórica realizado em chave pedagógica [...] baseado na concepção ciceroniana da língua, enquanto forma transmitida na qual é preservado o conteúdo herdado da civilização. A palavra - colocada a serviço da verdade, seja no nível gnosiológico, seja no nível moral fundamenta um projeto da oratória sagrada rumo à tradição iniciada

\footnotetext{
${ }^{28}$ Segundo MIRANDA (2001, p. 119): "Miguel Venegas, Cipriano Soares e Manuel Álvares bem como Pedro Perpinhão e Pedro da Fonseca, professor de Artes, haviam de marcar profundamente o ensino jesuítico em toda a Europa, durante cerca de dois séculos, até a extinção da Companhia, nomeadamente através da composição dos manuais que a Ratio estenderia a todos os colégios".

${ }^{29}$ Cipriano Soares nasceu em Ocaña em 1524 e entrou para a Companhia de Jesus em 1549, quando já se encontrava em Portugal. Devido à sua grande experiência pedagógica, foi um dos fundadores do Colégio de Jesus (ou Santo Antão) de Lisboa, vindo depois reforçar o corpo docente do Colégio das Artes de Coimbra quando, em 1555. D. João III o entregou à Companhia (Miranda, 2001).
} 
por Agostinho no De Doctrina Cristiana e apoiada na tradição patrística e humanista.

A arte retórica, segundo Soáres (1580), compõem-se de cinco partes: inventio, dispositio, elocutio, memoria, actio (MASSIMI, 2005). A elocutio, a boa e elegante enunciação de pensamentos através das palavras, ganha especial enfoque. Deixa de ter destaque apenas como adorno do discurso, e passa a valorizar a dimensão sensorial auxiliando a tonicidade, intencionalidade e inteligibilidade da palavra devido ao valor atribuído ao componente sensorial do significante (MASSIMI, 2005).

A percepção sensorial, ou seja, o sensível, bem como a esfera corporal e a préconceitual são valorizadas. Estas alimentam a faculdade imaginativa, o lugar interior onde razão e afetividade unem-se. A palavra eloquente - a expressão do pensamento necessita de um veículo sensível para existir e transitar, tal suporte é dado pela imagem: "Portanto, a retórica enfatiza a função de sinal que a imagem tem, utilizando-se de processos analógicos e imaginativos" (MASSIMI, 2005, p. 97).

Outro aspecto relevante a ser citado no compêndio de Soares (1580), é a retomada da tradição retórica do uso da memória. São levados em conta os processos de ordenação e de associação que lhe são fundamentais, segundo a tradição, para elaboração e memorização do discurso. Uma forma de mnemotécnica é estabelecida, "trata-se de fixar no pensamento lugares imaginários onde colocar aquilo que deve ser lembrado, de modo que a ordem dos lugares guarde a ordem das coisas, a partir da ordem das imagens em seu acervo" (MASSIMI, 2005, p. 98).

Com efeito, na obra de Soares (1660) os clássicos gregos e latinos são retomados, conceitos e conteúdos dispersos em vários livros estão ali compilados. No âmbito da Companhia de Jesus os clássicos pagãos são reconhecidos como uma produção lícita e valiosa para a constituição da oratória religiosa:

...a pedagogia da palavra no âmbito da Companhia enraíza-se na teologia inaciana do homem natura: depuradas do paganismo, as artes clássicas da palavra são uma espécie de teatro da memória do homem natural, herdeira do pecado mas também da primeira revelação. Por isso, os clássicos da retórica podem se tornar um manancial riquíssimo para a oratória sagrada (MASSIMI, 2005, p. 99). 


\section{Capítulo V: Considerações finais}

Essa tessitura de saberes e a concepção de homem, representados aqui por meio da obra de Vieira, estiveram presentes no século XVII luso-brasileiro. A composição da visão de mundo desse passado histórico é entremeada por essas concepções, ao mesmo tempo em que as sustenta. O estudo do tema indicou os conceitos de imaginação e memória, enquanto ideias psicológicas, como chaves de leitura para compreender de que forma, na época, se estruturavam os conhecimentos sobre a vida interior do homem e seu congraçamento com a realidade do mundo material.

O homem envolvido em uma dinâmica afetiva pode ter em seu interior a fonte de todos os enganos, mas também da salvação. São as relações travadas entre conhecimento e afetos que definem o modo pelo qual o ser humano perceberá o mundo e conceberá a si mesmo, e como tal atuará na realidade.

Converter é desenganar. Na dinâmica da vida interior, a raiz "psicológica" da persuasão presente na retórica, consiste em mobilizar os sentidos internos através da vontade - a qual deve seguir a razão. Pelo uso da palavra com toda a sua força figurativa, procura mostrar as razões do Bem de um objeto, suscita o interesse da imaginação, ao agradar interpela o apetite solicitando o aceite. Em termos "psicológicos" o desengano busca uma ordenação do universo anímico. Há aqui uma teoria do conhecimento onde o ser humano é considerado em sua integralidade. A percepção, os sentimentos, a vontade e a razão concorrem para que se estruture o conhecimento e a capacidade de deliberar, fazer um juízo. Há a possibilidade de a vontade ser regida pelas paixões e apetites, ou de ser guiada pela razão. O desengano busca a apreensão de uma razoabilidade por parte do ouvinte entre os argumentos propostos e sua experiência enquanto sujeito.

Busca-se o justo lugar das paixões e apetites. Para Vieira o homem destituído da razão e com a vontade submetida às paixões, descaracterizaria sua humanidade. Seria como que um bruto, animalizado ou reificado, um ser com a potência da razão, mas destituído dela. Não se desqualifica ou inferioriza-se, porém, as demais instâncias anímicas. Para ocorrer o conhecimento entram também em jogo tanto a percepção dos dados sensíveis (a capacidade sensorial do homem e sua corporeidade), quanto o cabedal emotivo do humano. Vieira busca uma posição coerente do sujeito entre a experiência da pessoa em sua totalidade e sua relação com a realidade. 
A imaginação tem papel de destaque dentro dos processos anímicos apresentados nos sermões. Esta potência da alma é levada em conta dentro da construção da pregação. De acordo com os pressupostos da época (MASSIM, 2005), ao se propor uma pregação, é previamente considerado, que a prédica mobilize a imaginação a seu favor para alcançar a persuasão. Por meio da imaginação simplifica-se o processo comunicativo e potencializa-se o uso da palavra. As imagens produzidas ou retomadas pela imaginação possuem forte apelo persuasivo, elas convocam outros elementos da dinâmica anímica, como as paixões e as outras potências, como a memória, o entendimento e a vontade. Consideramos também, que segundo os sermões, é a partir do património imaginativo de cada pessoa, ou seja, a maneira como cada um produz, evoca e se utiliza de suas imaginações, que indicará o modo de cada um estar no mundo. Como foi visto, o conhecimento de si, o governo das paixões, a capacidade de entendimento, a liberdade da vontade, e ainda as percepções e interpretações da realidade passam necessariamente pela imaginação.

A memória nos sermões se apresenta dentro da influência da tradição ocidental, tendo na perspectiva de Agostinho de Hipona (1997) a referência sobre o papel desta potência da alma. A potência memorativa, por meio de sua capacidade de vascular os fatos ocorridos, se torna instrumento importante para a razão atuar. A memória auxilia a capacidade intelectiva do homem a estabelecer juízos mais verdadeiros, pois disponibiliza ao intelecto a dimensão temporal da realidade. $O$ entendimento não se circunscreve ao imediato, mas busca de modo quase silogístico uma compreensão mais ampla dos fatos distribuídos no tempo. Nos sermões, o conceito do "fazer memória" possui uma função ética muito importante, ao se fazer memória de algo, com o auxílio da imaginação, faz-se o que está ausente, presente. Ao estar diante deste ausente/presente, altera-se o posicionamento e o comportamento da pessoa. Ao presentar Deus, os pecados, a profissão religiosa, pessoas, as obras, ou outros tópicos, é suscitado na pessoa um modo de agir condizente com a presença que lá está, indicando uma ética.

Observamos também o fato de Vieira dividir com seu auditório elementos teóricos, que compõem a própria constituição da pregação. Há metáforas para explicar o funcionamento anímico e a maneira como este atua. Explicita como nos persuadimos das coisas e como nos enganamos na percepção do mundo. Em metalinguagem enquanto pregava e persuadia, falava da pregação e persuasão. Tratando-se apenas de um discurso para convencer o outro, não haveria sentido em fornecer a este outro os 
métodos e os porquês do convencimento. Destarte, é implícito na metanóia o posicionamento do sujeito de forma a estabelecer um juízo frente ao que lhe é proposto. O que diferencia o sermão de outros gêneros oratórios. Como na maiêutica socrática, Vieira chama seu ouvinte a parturejar a verdade que lhe é intrínseca. A verdade não é dada pelo pregador, mas reconhecida em si pelo sujeito. O sermão deve informar, deleitar e convencer. Para tal, deve trazer em si um valor heurístico, ou seja, possibilitar de modo pedagógico que o ouvinte chegue por si só a verdade. Isto se dá somente se reconheço no outro uma dinâmica para percorrer este caminho, uma experiência interna que direcione esta aprendizagem.

Vieira conta com um posicionamento de seu ouvinte, onde este traz em si a possibilidade de receber o sermão em todos os seus aspectos. A confiança na adesão presente em seu auditório, aprioristicamente, é o que lhe permite pregar e ter a pretensão de colher o "fruto" desta pregação, a metanóia. Emerge uma apropriação retórica da teologia feita no barroco onde "a ação eficaz sobre o fiel, e, portanto, sobre a história, torna-se forma fundamental de descoberta da verdade apreensível nela" (PÉCORA, 1994).

Entendemos que fica a necessidade de ampliar a reconstrução histórica dos saberes psicológicos contidos nos sermões do jesuíta Antônio Vieira, bem como apresentar mais apontamentos para a antropologia filosófica que os constitui. Apesar de estarem presentes no trabalho, foram vistos de soslaio. Por exemplo, a concepção de vida psíquica nos sermões é muito mais cheia de meandros do que conseguimos apresentar aqui. $\mathrm{O}$ engenho retórico e a acomodação que fazem proeminente $\mathrm{o}$ dinamismo psíquico e outros saberes psicológicas na obra, também os obscurecem e velam-lhes, sendo quase necessária uma hermenêutica para resgatá-los. Em Vieira, a psicologia filosófica - em sua teorética e práxis - é constituída como meio e não como fim.

Em Vieira, a esfera do psiquismo contingente ao homem é elaborada dentro da concepção de homem integrado tanto em seu campo interior, seus afetos, paixões, vontade, intelecto, espírito, que se articulam entre si, como integrado ao mundo. Este Homem só se atualiza e tem sentido de ser, porque está imerso em uma realidade concreta, num mundo sensível; este último é ligado diretamente a um mundo transcendente, através da "sacramentalidade", ou seja, da possibilidade de todas as coisas e fatos serem sinais e presentificação de um sentido maior e mais amplo de transcendência, aqui ligado a uma universalidade, e, por conseguinte, à divindade. 
Fazendo uma analogia entre a alma aristotélico-tomista e o ser do homem do século XVII, sendo a primeira una e indissociável, ao mesmo tempo em que se apresenta em suas três modalidades (vegetativa, sensitiva e racional), também o homem constitui-se de sua materialidade, de sua psique e de seu aspecto transcendente, os quais se articulam entre si, ao passo que simultaneamente são a imagem de um todo.

E é este o motivo da pregação possuir toda essa sua força e reunir tantos fatores e conceitos em torno de si, justificando assim o destaque que tem no período: é a palavra laboriosa que perpassa toda a estrutura do homem - psique, materialidade e transcendência - e a articula de forma conjunta e unitária, integrando-a. A palavra ao desenganar, restitui o valor ético da ação humana - a morada própria do homem, um modus vivendi -, promovendo a integração da estrutura humana, o homem total. A palavra torna-se farmacon.

Por fim dizemos, que o sermão é por natureza um género prescritivo, ou seja, procura a afirmação de significados e sentidos. Diferentemente do discurso geral das ciências humanas, apontado por Dosse (2001), que em nome de um busca de uma pretensão cientificidade, abre mão de seu passado clássico, buscando uma proximidade com as ciências da natureza, enaltece o discurso descritivo.

Essa porém é uma questão a qual transcende o objeto de estudo e põem-se ao pesquisador. Obviamente na construção do conhecimento é inegável o valor descritivo para a própria construção dos dados, do corpus de pesquisa, porém no momento da escrita do discurso, de historiografar, há um tônus prescritivo em tal ato ao qual o pesquisador não pode se eximir. Há uma afirmação, uma prescrição implícita ou explícita na escrita do pesquisador. Aqui há uma tensão no discurso que busca uma valorização do universo cultural luso-brasileiro seiscentista que aponta para uma evidenciação dessa raiz cultural e sua colaboração para o conhecimento contemporâneo. Pensamos que a tentativa de apagamento dessa raiz, desvitaliza a construção do conhecimento contemporâneo. Dando-se isso seja pelo corte arbitrário, do conhecimento das ciências com seu passado clássico (filosófico), o que gera lacunas de sentido, ou um conhecimento desenraizado, onde ideias e conceitos perdem sua historicidade. Tornam-se fugazes, perdendo a dinâmica de tensão, de contradição dinamizadora que gera apropriação, ou refutação. E por isso que o resgate de saberes psicológicos pode ser bastante útil para a construção da psicologia moderna. 


\section{Referências}

ABBAGNANO, N. Dicionário de Filosofia. São Paulo: Marins Fonte, 2003

AGOSTINHO, A. Confissões. (trad. Maria Luiza Jardim Amarante). São Paulo: Paulus, 1997. (Original do século V)

AgOstinho, A. A Doutrina Cristã (N. de A. de Oliveira Trad.). São Paulo: Edições Paulinas, 1991. (Original do século V)

AQUINO, T. Suma Teológica, Vol. II. Parte I - Questão 78, art. 4. São Paulo: Edições Loyola, 2002. (Original latino do Século XII).

ARISTÓTELES. De Anima (trad. M. C. G. Reis). São Paulo: Editora 34, 2006.

Ética a Nicômaco. In: Aristóteles, Coleção Os Pensadores. São Paulos: Nova Cultura, 1996

Retórica. Madrid: Editorial Gredos, 1994 (Original grego do Século IV a.c.)

BERGAMO, M., L'Anatomia dell'Anima. Da François de Sales a Fénelon. Bologna: Il. Mulino, 1991.

BOXER, C. R., O Império Colonial Português (1414-1825). Lisboa: Edições 70, 1969.

CHARTIER, R., História Cultural, Entre Práticas e Representações, (trad. Maria Manuela Galhardo), Lisboa, 1988.

CICERO, M. T., De L'Orateur Livre II, Paris. Société D'édition “Les Belles Lettres", 1966.

DE CERTEAU, M., A Escrita da História (trad. Maria de Lourdes Menezes). São Paulo: Forense-Universitária, 2000

DOBRANSZKY, E. A. Memória e imagem na retórica e na poesia da Renascença [versão eletrônica]. Horizontes, v. 23, n. 1, p. 7-17, jan./jun. 2005. Disponível em: <http://www.saofrancisco.edu.br/edusf/publicacoes/RevistaHorizontes/Volume_03/uplo adAddress/horizontes-2\%5B6215\%5D.pdf>. Acessado em: 5 de Jan. de 2010.

DOSSE, F., História e Ciências Sociais (trad. Fernanda Abreu) Bauru, São Paulo: EDUSC, 2004, p. 200.

A história a prova do tempo: da história em migalhas ao resgate do sentido (trad. Ivone Castilho Benedetti), São Paulo, Editora UNESP, 2001

FALCON, F. C. J. A cultura Renascentista Portuguesa. Semear 1, Disponível em: <http://www.letras.puc-rio.br/catedra/revista/1Sem_03.html>. Acessado em: 25 de Out. 2009 
FUMAROLI, M. L'age de l'eloquence. Rhétorique et res literária de la Renaissance au seuil de l'époque classique. Genève: Droz, 1980.

GIUSSANI, L. O Senso Religioso. Brasília: Editora Universa, 2009.

GRANADA, L. Seis Libros De La Retorica Eclesiastica O Dela Manera De Predicar (trad. Nossa). edição espanhola da Biblioteca dos Autores Cristianos, Tomo terceiro, 1945.

GONTIJO, S. R. e MASSIMI, M. Retórica e Dinamismo Psíquico em Sermões de Antônio Viera - Cadernos de Psicologia e Educação Paidéia. Vol. 17 n 37 maio-ago 2007. Disponível em www.scielo.br/paideia. Acessado em: 15 mai. 2009.

IPARRAGUIRRE, I., SI. Répertoire de spiritualié ignatienne, de la mort de S. Ignace à celle du P. Aquaviva,. Roma: Institutum Historicum Societatis Iesu, 1961(original de 1556-1615).

JORI, G. Per evidenza. Conoscenza e segni nell’età barocca. Torino: Marsílio, 1998.

LOYOLA, I. Exercícios Espirituais. (trad. Centro de Espiritualidade Inaciana de Itaici). São Paulo: Edições Loyola, 2002.

MARAVAL, J. A. A cultura do barroco, São Paulo: EDUSP, 1997.

MASSIMI, M. Ideias Psicológicas na cultura luso-brasileira, do século XVI ao século XVIII. In: JACÓ-VILELA, A. M.; FERREIRA, A. A. L.; PORTUGAL, F. T. História da Psicologia: Resumos e percursos (org.). Rio de Janeiro: Nau, 2008.

e FREITAS, G. R. Acomodação Retórica e Adaptação Psicológica

na Pregação Popular dos Jesuítas na Terra de Santa Cruz. Mnemosine Vol.3, nº 1 , p. 111-135, 2007.

Alimentos, palavras e saúde (da alma e do corpo), em sermões de pregadores brasileiros do século XVII. História, Ciências, Saúde - Manguinhos, v. 13, n. 2, p. 253-70, abr.-jun. 2006.

2005.

Palavras, almas e corpos no Brasil colonial. São Paulo: Edições Loyola,

MARROU, H. I. Sobre o Conhecimento Histórico. Rio de Janeiro: Zahar Editores, 1978.

MIRANDA, M. Cipriano Soares e Miguel Venegas; o poema dedicatório dos De Arte Rhetorica Libri Tres (1562), em Boletim de Estudos Clássico, 35, p. 119-123, dez. 2001. Disponível em: <http://www.uc.pt/fluc/eclassicos/publicacoes/bec35>. Acessado em: 02 de fev. 2009.

PÉCORA, A. Para ler Vieira: As 3 Pontas das Analogias nos Sermões, em Estudios Portugueses 3, Revista de Filologia Portuguesa, Salamanca, 2003. 

pp. 399-414.

O desejado. Em: Novaes, O Desejo. São Paulo: Companhia das Letras, 1995, Teatro do sacramento. São Paulo: Edusp-Editora Unicamp, 1994.

REALE, G., e ANTISERI, D., História da Filosofia: Antiguidade e Idade Média, Volume I. São Paulo: Paulinas, 1990.

SOARES, C., (1580) De arte retorica. Ex Aristotele, Cicerone et Quintiliano precipue deprompt, nunc ab eodem recogniti et multis in locis locupletis. Roma, $\mathrm{F}$. Zanettum. Libri III.

TESAURO, E. Il cannocchiale aristotelico. In E. Raimond, Trattatisti e narratori del seicento. La letteratura italiana, Vol. 36, pp. 19-106. Milano: Ricciardi, 1965.

VIEIRA, A, Obras Completas Do Padre Antônio Vieira. Sermões 5 v. Porto: Artes Gráficas 1993.

ZANLONGHI, G. (2003). La psicologia e il teatro nella riflessione gesuitica europea del cinque-seicento [versão eletrônica]. Memorandum, 4, 61-85., de http:\\ www.fafich.ufmg.br/ memorandum/artigos04/Zanlonghi01.htm. Acessado em: 25 ago. 2009. 